\title{
Recombinant Adeno-Associated Viral Vectors (rAAV)-Vector Elements in Ocular Gene Therapy Clinical Trials and Transgene Expression and Bioactivity Assays
}

\author{
Thilo M. Buck ${ }^{1}$ and Jan Wijnholds ${ }^{1,2, *(1)}$ \\ 1 Department of Ophthalmology, Leiden University Medical Center (LUMC), \\ 2333 ZC Leiden, The Netherlands; t.m.buck@lumc.nl \\ 2 Netherlands Institute of Neuroscience, Royal Netherlands Academy of Arts and Sciences (KNAW), \\ 1105 BA Amsterdam, The Netherlands \\ * Correspondence: J.Wijnholds@lumc.nl; Tel.: +31-71-52-69269
}

Received: 20 May 2020; Accepted: 10 June 2020; Published: 12 June 2020

\begin{abstract}
Inherited retinal dystrophies and optic neuropathies cause chronic disabling loss of visual function. The development of recombinant adeno-associated viral vectors (rAAV) gene therapies in all disease fields have been promising, but the translation to the clinic has been slow. The safety and efficacy profiles of rAAV are linked to the dose of applied vectors. DNA changes in the rAAV gene cassette affect potency, the expression pattern (cell-specificity), and the production yield. Here, we present a library of rAAV vectors and elements that provide a workflow to design novel vectors. We first performed a meta-analysis on recombinant rAAV elements in clinical trials (2007-2020) for ocular gene therapies. We analyzed 33 unique rAAV gene cassettes used in 57 ocular clinical trials. The rAAV gene therapy vectors used six unique capsid variants, 16 different promoters, and six unique polyadenylation sequences. Further, we compiled a list of promoters, enhancers, and other sequences used in current $\mathrm{rAAV}$ gene cassettes in preclinical studies. Then, we give an update on pro-viral plasmid backbones used to produce the gene therapy vectors, inverted terminal repeats, production yield, and rAAV safety considerations. Finally, we assess rAAV transgene and bioactivity assays applied to cells or organoids in vitro, explants ex vivo, and clinical studies.
\end{abstract}

Keywords: retina; retinal pigment epithelium (RPE); adeno-associated virus (AAV); promoter; enhancer; polyadenylation; pro-viral plasmid; Cas9; transgene expression assay (TEA); biological activity assay (BAA)

\section{Introduction}

Many reviews have been written on recombinant adeno-associated virus vector (rAAV) tropism in ocular tissue, rAAV host cell infection, and potential rAAV-treatable inherited retinal diseases [1-9]. Here, we will review the ocular gene therapies developed over the past 20 years focusing on the diversity of elements incorporated in rAAV vectors. Further, we will discuss how the vectors were generated, tested, and further modified to increase the potency and safety of the gene expression vector. After that, we will provide a library of validated elements that allows other researchers to streamline the modification of their vectors. Novel medical therapies, such as gene therapies, need to be carefully optimized to demonstrate their efficacy and safety before going into clinical human trials [10]. That is why, it is crucial to choose the most relevant biological model(s) (in vitro, in vivo, and ex vivo models) to test an optimized gene therapy vector in a transgene expression assay (TEA) and test the transgene activity in a biological activity assay (BAA). Thus, we will explore the developments in preclinical 
models, for example, cellular models, human induced pluripotent stem cell (hiPSC) derived retinal organoid disease models, retinal explant models, and tropism studies in non-human primates.

\subsection{Why Viral Vector-Based Gene Augmentation Therapy for Ocular Diseases?}

The environment of the eye offers a wide range of treatment possibilities due to the blood-retinal barrier of the eye decreasing viral vector diffusion to other organs and systemic immune activation. The retina consists of terminally differentiated cells thus reducing gene integration and chromosomal rearrangements. Many noninvasive techniques are available to monitor the treatment response.

Treatments aim to slow the progression of the inherited retinopathies by reducing retinal cell death, augmenting retinal function, replacing cells, or creating an artificial retina (retinal prosthesis). Preventing retinal cell death may be achieved by gene therapy, cell therapy, other drug treatments, as well as dietary adjustments and even by changes in lifestyle. Such as cigarette smokers giving up smoking or people taking too much high Vitamin E supplements [11]. Currently, there are only a few scientifically proven preventive or protective actions available to patients with inherited retinal diseases. Some preventative measures may potentially decrease patients' quality of life, such as the continuous use of eye protection, photochromic lenses, or restriction to light exposure. Successful viral gene therapies can last many years. This could alleviate the disease burden thereby increasing the patients' quality of life tremendously.

The ocular gene therapy strategy targets the basis of inherited retinopathies: the gene. With this strategy, the variant (disease-causing) gene is silenced, replaced, or repaired in the target cell (see Figure 1). The primary gene cassette carrier systems for ocular diseases has been the recombinant viral vector. However, many other potential technologies have been developed alongside, including exosomes/liposomes, antisense oligonucleotides (AONs), electroporation of naked DNA/RNA, or application of nanoparticles [12,13]. In most clinical retinal gene therapy studies, the vector of choice is the rAAV gene expression vector [14]. Two genes that do not fit in a conventional rAAV gene cassette (MYO7A linked to Usher syndrome Type 1B and ABCA4 to Stargardt disease) have been delivered to the retina by recombinant lentiviral expression vectors instead [15-18]. Moreover, another large gene, CEP290, can be rescued on the mRNA level by antisense oligonucleotides (AONs; QR-110 for Leber congenital amaurosis (LCA), with CEP290; QR-421a for LCA with USH2A) [19]. An important consideration is how the therapeutic product is administered to the target cells. The most common method is the subretinal or the intravitreal injection. Subretinal injections can target a focal area (e.g., macula), favoring high vector delivery to the retinal pigment epithelium (RPE), photoreceptors, and Müller glial cells. Intravitreal injections efficiently target the ganglion cell layer and spread the rAAV to the whole retina in rodents but not in the primate retina due to the shielding properties of the inner limiting membrane. Figure 1 describes the considerations for choosing a gene therapy strategy.

\section{2. $r A A V$ Gene Therapy for Ocular Diseases-Advantages and Disadvantages}

rAAV DNA carrier systems have been successfully used because they have a plethora of advantages: (1) They express the transgene within days or weeks and can reach full expression levels after 4-6 weeks in vivo $[20,21]$. (2) rAAV DNA carrier systems allow long-term treatment for at least ten years in dogs [22], (3) and primarily deliver their gene cassette in episomal concatemers into the nucleus [23]. (4) rAAV DNA carrier systems spread well within tissues to target large retinal patches [24]. (5) The capsid composition can be adjusted to fit one's goals [25]. (6) rAAV injections have been very safe with a low number of serious adverse events (SAE) in clinical trials [26]. On the other hand, rAAVs similar to other viral strategies, have limitations such as: (1) A small gene cassette capacity (up to $4.6 \mathrm{~kb}+2 \times 145 \mathrm{bp}$ ITRs). (2) The instability of the inverted terminal repeats (ITRs). (3) The need for high viral load for transgene expression. (4) A humoral immune reaction can be evoked. The immune reactions range from induction of neutralizing antibodies that reduce the number of capsids reaching the target cells to the innate immune pathways silencing the gene cassette within the host cell, as well as the cell-mediated T-cell immune response against foreign protein expression [27]. It is important to 
carefully consider the advantages of using rAAVs over other attractive strategies (Figure 1). In the following, we will describe how successful gene cassettes (vectors) have been designed for rAAV vectors (vectorology) that entered the clinical phase.

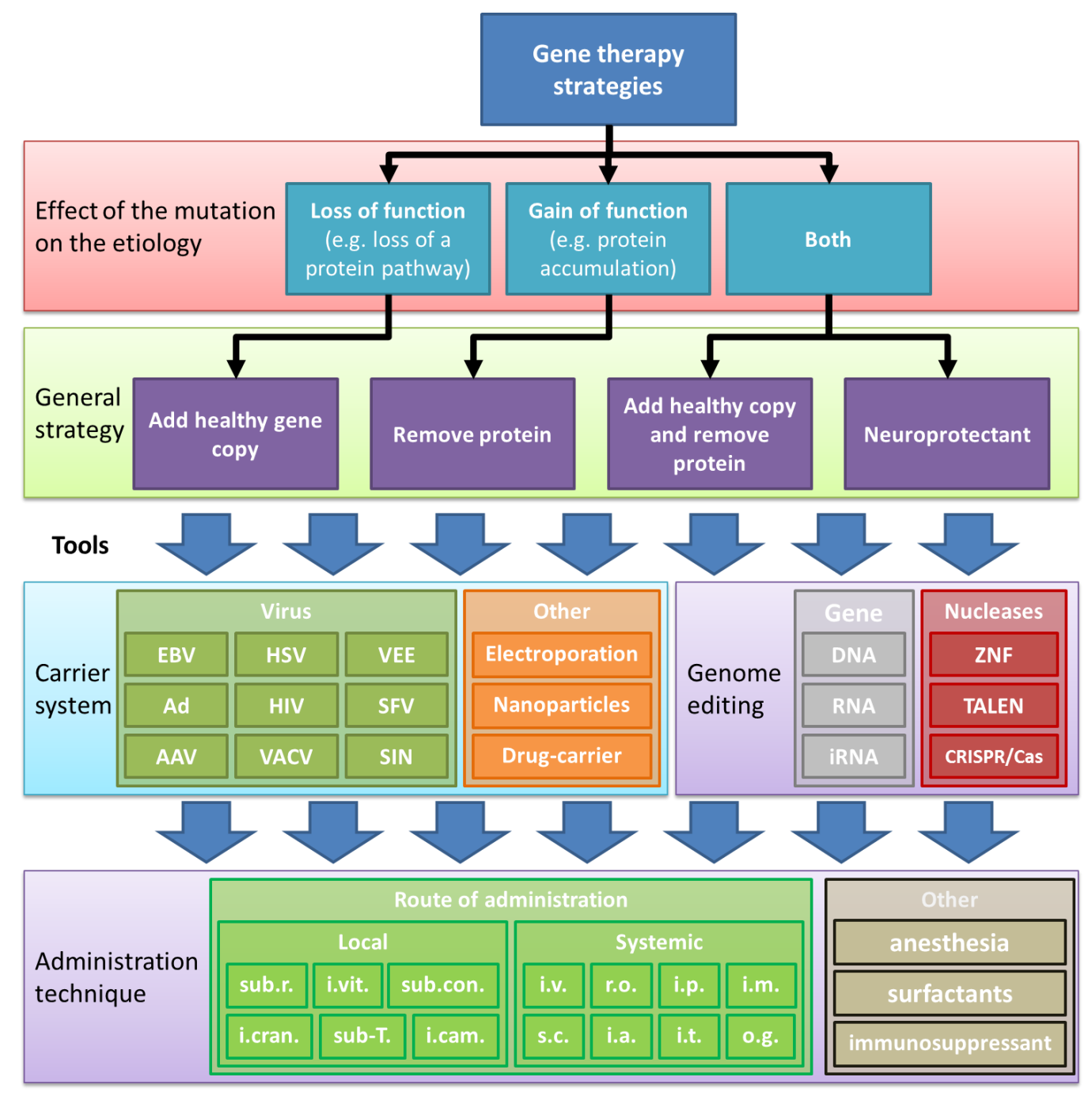

Figure 1. An overview of retinal gene therapy strategies. The effects of the gene variations determine the gene therapy rescue strategy to be applied. Physical DNA delivery includes electroporation, sonoporation, magnetofection, and bioballistic (gene gun) methods. Viruses: AAV, Adeno-associated virus; Ad, Adenovirus; alpha, alphavirus; Epstein-Barr virus (EBV); FV, Foamy virus; HSV, Herpes simplex virus; HIV, Human immunodeficiency virus; VACV, Vaccinia virus. Nucleases: ZNF, Zinc-finger nuclease; TALEN, transcription activator-like effector nuclease; CRISPR/Cas, clustered regulatory interspaced short palindromic repeat (CRISPR)/Cas-based RNA-guided DNA endonuclease. Route of administration: i.cranial, intracranial; i.a., intraarterial; i.cam., intracameral; i.m., intramuscular; i.v., i.t., intrathecal; intravenous (e.g., tail vein or facial vein); i.vit, intravitreal; o.g., oral gavage; r.o., retro-orbital; sub.r, subretinal; sub-T, sub-Tenon; sub.con., sub conjunctiva; s.c., subcutaneous.

\section{Ocular rAAV Vector-Based Therapies in Clinical Trials}

Inherited retinal dystrophies (IRDs) and inherited optic neuropathies (IONs) are chronic and disabling disorders affecting $1 / 2000$ to $1 / 4000$ people worldwide. They display considerable genetic, symptomatic, and anatomical heterogeneity (Figure 2A; [28-30]). More than 250 genes can cause IRDs and IONs [31]. IRDs include pigmentary retinopathies, maculopathies, and stationary retinopathies. Patients with pigmentary retinopathies regularly suffer from night blindness, tunnel 
vision, and photophobia while maculopathies lead to the loss of color vision and accurate vision. Gene products worsening the ciliary development or the mitochondria function can cause syndromic IRDs. Common ciliary retinopathies are Usher syndrome, Bardet-Biedl syndrome, and Senior-Løken syndrome [32-34]. Some disease genes also affect the optic nerve causing vision loss by disturbing the electrical transmission from the ganglion cells to the cortex. The progressive degeneration of the optic nerve leads to ischemic optic neuropathies (IONs).
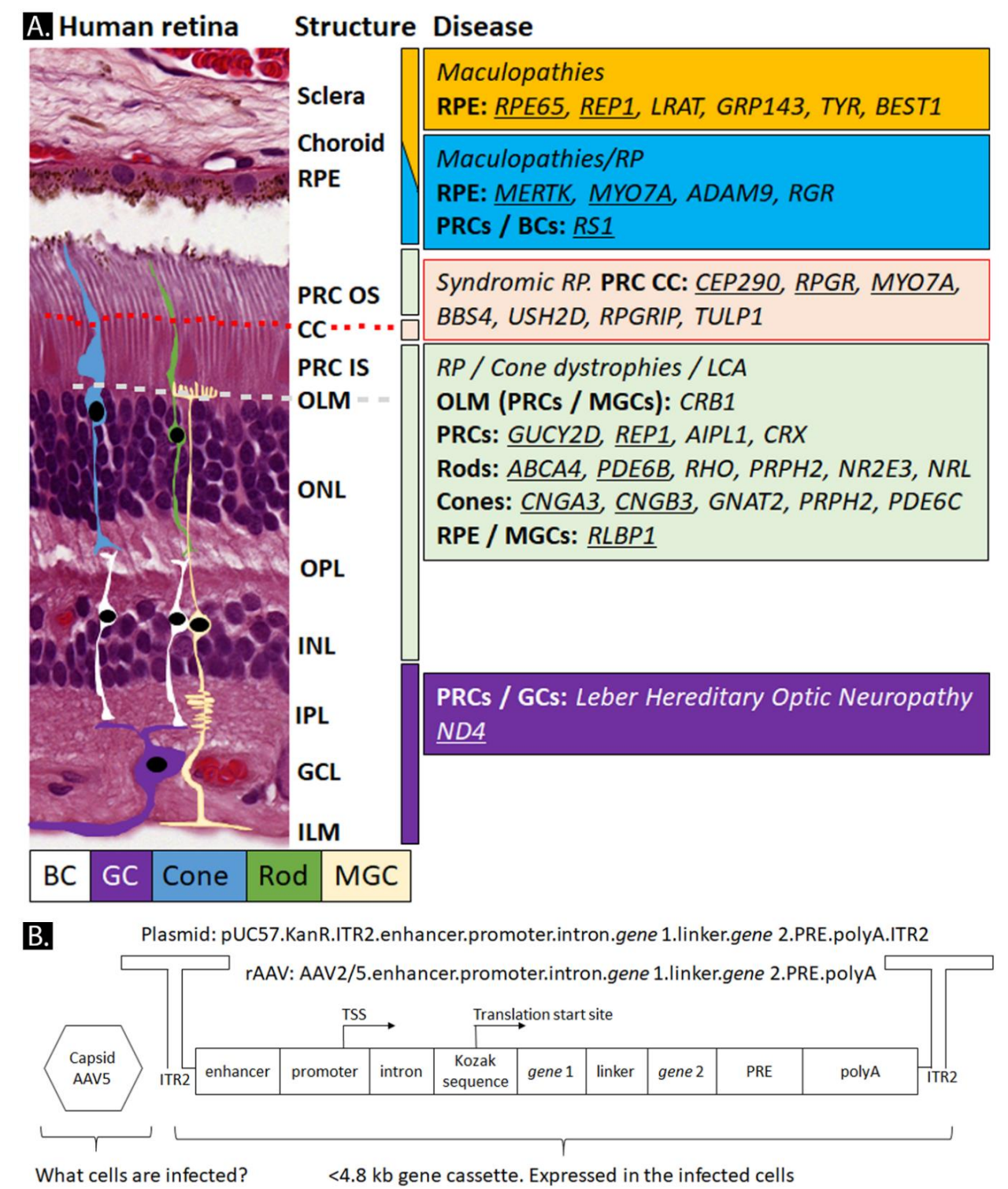

Figure 2. The development of recombinant AAV vectors targeting ocular diseases. (A) Main location (arrow) of frequent gene products (genes indicated) causing retinal diseases (color), and recombinant adeno-associated viral vectors (rAAV)-gene supplementation therapy genes (in clinical trials; underlined genes). (B) Hypothetical rAAV gene cassette and the corresponding plasmid. AAV5, adeno-associated viral vector serotype 5; $\mathrm{BC}$, bipolar cell; Cone, cone photoreceptor; $\mathrm{CC}$, connecting cilium; GC, ganglion cell; GCL, Ganglion Cell Layer; ILM, Inner Limiting Membrane; IPL, Inner Plexiform Layer; ITR, inverted terminal repeat; KanR, kanamycin resistance gene; LCA, Leber congenital amaurosis; MGC, Müller glial cell; ONL, outer nuclear layer; OPL, Outer Plexiform Layer; PRC IS, photoreceptor inner segment; PRC OS, photoreceptor outer segment; polyA, polyadenylation sequence; PRE, post-transcriptional gene regulatory element; $\mathrm{RP}$, retinitis pigmentosa; RPE, retinal pigment epithelium; rod, rod photoreceptor; TSS, transcription start site. 
rAAVs are one of the most promising gene augmentation tools for the treatment of inherited ocular diseases. For instance, more than $33 \mathrm{rAAV}$ gene therapies have been delivered to clinical trials (Table 1, Figure 2A). The current strategy of many ocular gene therapy trials is to shuttle and integrate a wild-type copy of the gene to the RPE or photoreceptor cells (Figure 2A). Figure 2A provides a list of genes intensively investigated for gene therapy. This basic rAAV gene delivery vector can consist of two inverted terminal repeats (ITRs) of the AAV serotype 2 (ITR2), a promoter, a wild-type copy of the cDNA of the gene-of-interest, as well as other enhancers or transcript stabilizing elements, an intron, and a polyadenylation sequence (Figure 2B). The promoter can be of viral origin, shortened-native, or synthetic. Many new promoters incorporate conserved transcription factor binding sites (TFBS), called enhancers, to boost transcription. Additional sequences can be added to a gene cassette, including fluorescent probes, linkers, base editors, nuclear localization signals, or short-hairpin RNAs (See Figure 2B and Section 3).

The first ocular rAAV clinical trial for RPE65 was initiated in 2007. Over the years, five different AAV-RPE65 products were tested in a total of 13 clinical trials by Applied Genetic Technologies Corporation (AGTC; Alachua, USA), Hadassah Medical Organization (Jerusalem, Israel), Spark Therapeutics (Philadelphia, USA), University of Pennsylvania (Philadelphia, USA), MeiraGTx (London, UK), Nantes University Hospital (Nantes, France), and University College London (London, UK). The clinical trial results lead to the first and only retinal gene therapy (so far) approved by the FDA in December 2017 and EMA in November 2018 (AAV-hRPE65v2; voretigene neparvovec-rzyl, LUXTURNA; Spark Therapeutics). The groundbreaking advancement was based on several approaches explored by different research teams concurrently. The five different strategies from the researchers delivered the RPE65 cDNA to RPE cells by subretinal administration employing three different capsids (rAAV2, rAAV4, and rAAV5. Table 1) having different tropism and infection properties. Dose finding studies have shown that a high number of rAAV particles $\left(>10^{12}\right.$ viral genomes $\left.(\mathrm{vg})\right)$ can give rise to transient inflammation in mice [35]. This hurdle can be tackled by increasing the vector potency that reduces the dose and the danger of inflammation. Switching the capsid to rAAV5 increased the transduction of RPE (target) cells lowering the dose requirement. A lower dose is generally achieved by using a reliable, robust, and strong promoter that expresses (physiological) relevant levels of the transgene in the normal as well as diseased retina. Many gene therapies have employed the ubiquitous expressing viral CAG promoter that achieves high vector expression in the retina over many years. However, native promoters may permit a more cell-specific and natural expression profile. Two native promoters have been used for the rAAV-RPE65 therapy, a $1.6 \mathrm{~kb}$ long native RPE65 promoter and later a promoter shortened to 750 bp (NA65p). The rAAV-NA65p-RPE65 gene expression vector also had other modifications (SV40 intron; Kozak sequence; codon optimization) to increase potency and cell-specificity of $h R P E 65$ expression. The shortened NA65p promoter was much less silenced in the disease mouse retina than the longer promoter construct [36]. The search for the best product demonstrates the complexity of implementing native promoters (RPE65p, NA65p) over ubiquitous strong promoters (CAG, CB-SB) in transcription regulation over different animal models and disease states. We will discuss the different promoters and elements in Section 3. Currently, the two products, rAAV2/5-NA65p-OPTIRPE65 and rAAV2/2-CAG-hRPE65v2 seemed to be at least as efficient in RPE65-deficient mouse retinal pigment epithelium [36]. 
Table 1. rAAV gene therapy products registered on clinicaltrials.gov.

\begin{tabular}{|c|c|c|c|c|c|c|c|c|c|}
\hline Disease & Year & Product & Capsid & Promoter & Intron & Other & Gene & PolyA & Production \\
\hline LCA & 2007 & $\mathrm{~h} R P E 65 \mathrm{v} 2$ & AAV2 & CAG & $\beta$-globin & & RPE65 & $\mathrm{bGH}$ & HEK293 \\
\hline LCA & 2007 & AAV-RPE 65 & AAV2 & CB-SB & & & RPE65 & SV40 & HEK293 \\
\hline LCA & 2008 & $\operatorname{tgAAG76}$ & AAV2 & hRPE65 & & & RPE65 & bGH & B50, helper adenovirus \\
\hline LCA & 2011 & HORA-RPE65 & AAV4 & hRPE65 & & & RPE65 & bGH & HEK293 \\
\hline LCA & 2016 & OPTIRPE & AAV5 & NA65 & SV40 & & RPE65 & SV40 & HEK 293 \\
\hline AMD & 2009 & sFLT01 & AAV2 & CAG & $\beta$-globin & & sFLT01 & bGH & HEK293 \\
\hline AMD & 2011 & OXB-201 & EIAV & CMV & & IRES + WPRE & Endo+ Angio & SIN-LTR & $?$ \\
\hline AMD & 2011 & AAV.sFlt-1 & AAV2 & CMV & Chimeric intron & & sFlt-1 & SV40 & HEK293 \\
\hline AMD & 2017 & RGX-314 & AAV8 & CAG/CB7 & $\beta$-globin & & $\begin{array}{c}\text { aVEGFAfabH.F2A } \\
\text { aVEGFfabL }\end{array}$ & $\begin{array}{c}\text { rabbit } \\
\beta \text {-globin }\end{array}$ & $?$ \\
\hline AMD & 2018 & HMR59 & AAV2 & CAG & $\beta$-globin $\mathrm{SD} / \mathrm{SA}$ & & sCD59 & bGH & $?$ \\
\hline AMD & 2018 & ADVM-022 & AAV2-7m8 & CMV & $\beta$-globin SD $\mathrm{Ig}^{\mathrm{SA}}$ & TLP-eMLP & sFLT01co & & Sf9 \\
\hline AMD & 2019 & GT005 & AAV2 & CBA & $\beta$-globin & WPRE & CFI & bGH & $?$ \\
\hline LHON & 2010 & AAV2-ND4 & AAV2 & CMV & 5'UTR COX10 & $\begin{array}{c}\text { 3'UTR } \\
\text { COX10(MTS) }\end{array}$ & ND4 & bGH & $\begin{array}{c}\text { HEK293, } \\
\text { HSV1-rc/DUL2 }\end{array}$ \\
\hline LHON & 2011 & scAAV2-P1ND4v2 & AAV2-tYF & smCBA & & ATP1(MTS); WPRE & ND4 & bGH & HEK293 \\
\hline LHON & 2014 & GSO10 & AAV2 & $\mathrm{CMV}$ & $\beta$-globin & COX10(MTS) & ND4 & $3^{\prime} \mathrm{COX} 10$ & HEK293 \\
\hline Stargardt & 2011 & SAR422459 & EIAV & CMV & & & $A B C A 4$ & SIN-LTR & HEK293 \\
\hline $\mathrm{CHM}$ & 2011 & AAV2.REP1 & AAV2 & CAG & $\beta$-globin $\mathrm{SD} / \mathrm{SA}$ & WPRE & CHM & bGH & HEK293 \\
\hline $\mathrm{CHM}$ & 2015 & AAV2.REP1 & AAV2 & CAG & $\beta$-globin & & $\mathrm{CHM}$ & $\mathrm{bGH}$ & HEK 293 \\
\hline $\mathrm{RP}$ & 2011 & AAV2.MERTK & AAV2 & hVMD2 & $\mathrm{SV} 40^{\mathrm{SD} / \mathrm{SA}}$ & & MERTK & $\begin{array}{l}\text { SV40. } \\
\text { bGH }\end{array}$ & HEK293 \\
\hline Usher & 2012 & UshStat & EIAV & CMV & & WPRE & MYO7A & SIN-LTR & HEK293 \\
\hline Usher & 2018 & QR-421a & & & & AON-USH2A & & & Synthetic \\
\hline LCA & 2019 & EDIT-101 & AAV5 & U6; hGRK1 & $\mathrm{SV} 40^{\mathrm{SD} / \mathrm{SA}}$ & gRNA-CEP290 & SaCas9 & Synthetic & HEK 293 \\
\hline LCA & 2019 & AAV5.GUCY2D & AAV5 & hGRK1 & $\mathrm{SV} 40^{\mathrm{SD} / \mathrm{SA}}$ & & GUCY2D & bGH & HeLaS3 \\
\hline XLR & 2015 & AAV2-tYF.RS1 & AAV2-tYF & $\mathrm{smCB}$ & $\beta$-globin $\mathrm{SD} / \mathrm{SA}$ & WPRE & $R S 1$ & SV40 & rHSV/sBHK \\
\hline XLR & 2017 & scAAV8-RS1 & AAV8 & hRS1 & RS1 & IRBP enhancer & RS1 & $\begin{array}{l}\text { Human } \\
\beta \text {-globin }\end{array}$ & HEK293 \\
\hline ACHM & 2015 & AAV2-tYF.CNGB3 & AAV2-tYF & PR1.7 & $\mathrm{SV} 40^{\mathrm{SD} / \mathrm{SA}}$ & & CNGB3 & SV40 & rHSV/sBHK \\
\hline ACHM & 2015 & AAV.CNGA3 & AAV8 & hCAR & & WPREm & CNGA3 & bGH & HEK293 \\
\hline $\mathrm{ACHM}$ & 2016 & AAV8.CNGA3 & AAV8 & hG1.7 & & & CNGA3 & SV40 & HEK293 \\
\hline ACHM & 2016 & AAV8.CNGB3 & AAV8 & hCAR & & & CNGB3 & SV40 & HEK293 \\
\hline $\mathrm{ACHM}$ & 2019 & AGTC-402 & AAV2-tYF & PR1.7 & $\mathrm{SV} 40^{\mathrm{SD} / \mathrm{SA}}$ & & CNGA3 & SV40 & rHSV/sBHK \\
\hline
\end{tabular}


Table 1. Cont.

\begin{tabular}{|c|c|c|c|c|c|c|c|c|c|}
\hline Disease & Year & Product & Capsid & Promoter & Intron & Other & Gene & PolyA & Production \\
\hline $\mathrm{RP}$ & 2017 & AAV8.RPGR & AAV8 & hGRK1 & & & RPGRco-ORF15 & $\mathrm{bGH}$ & HEK293 \\
\hline $\mathrm{RP}$ & 2017 & AAV-RPGR & AAV5 & hGRK1 & $\mathrm{SV} 40^{\mathrm{SD} / \mathrm{SA}}$ & & RPGRco-ORF15-Long & SV40 & HEK293 \\
\hline $\mathrm{RP}$ & 2017 & AGTC-501 & AAV2-tYF & hGRK1 & $\mathrm{SV} 40^{\mathrm{SD} / \mathrm{SA}}$ & & RPGRco-ORF15 & SV40 & rHSV/sBHK \\
\hline $\mathrm{RP}$ & 2017 & RST-001 & AAV2 & CAG & $\beta$-globin SD/SA & WPRE & Chop2/ChR2 & bGH & HEK293 \\
\hline $\mathrm{RP}$ & 2017 & GS030 & AAV2-7m8 & CAG & & & ChrimsonR-tdT & bGH & $?$ \\
\hline $\mathrm{RP}$ & 2020 & BSO1 & AAV? & $?$ & & & Chr90-FP & $?$ & $?$ \\
\hline $\mathrm{RP}$ & 2017 & AAV5.PDE6B & AAV5 & hGRK1 & & & PED6B & bGH & HEK293 \\
\hline $\mathrm{RP}$ & 2017 & СРК850 & scAAV8 & sRLBP1 & $\mathrm{mSV} 40^{\mathrm{SD} / \mathrm{SA}}$ & & $R L B P 1$ & SV40 & HEK293 \\
\hline
\end{tabular}

Ordered on registration date (year) and disease. Full description, size (bp) of elements, and citations can be found in Table S1. 
The time it takes to move from a proof-of-concept study to a clinical trial is accelerating. Numerous breakthrough clinical phase I/II trials were already initiated over the recent years (see Figure 2A and Table 1) paving the way for therapies to come. Many more clinical trials, including for CRB1-related retinitis pigmentosa, will be initiated in the coming years. The acceleration is further exemplified by the shortened time it takes in moving from phase I/II to II/III clinical trials. ProQR moved from clinical trial phase I/II to II/III within one year (Product: AON QR-110 for CEP290 mRNA). GenSight Biologics (Product: GS010, rAAV2/2-ND4 for LHON) was able to move to clinical trial phase III within four years. NightstaRx Ltd. initiated the XOLARIS clinical trial phase I/II with a linked clinical trial phase III for Usher's syndrome in which 200 enrolled patients in the study phase I/II could become included in the follow-up clinical trial phase III study (rAAV2/8-RPGR-ORF15). Furthermore, new products are constantly being developed, offering patients the hope of receiving a lasting therapy. Such as, age-related macular degeneration (AMD) that may be treated either by monthly administration of aflibercept (Product ProCon consists of sFLT01, an antibody-like product; Regeneron Pharmaceuticals) or by potentially long-lasting rAAV-therapy (Product: AAV2-sFLT01; Sanofi/Genzyme). Other exciting new ocular rAAV therapies are displayed in Figure 2A and Table 1. All clinical trial identifiers, clinical trial start dates, and products can be found in Table S1.

The generation of the first recombinant AAV (rAAV2) was already described by the labs of Nick Muzyczka and Barrie Carter in 1982-1983 [37,38]. Many more AAV capsids have been found and engineered that are able to slow AAV capsid immune detection and degeneration and increase cell-specific transduction (see Section 5). So far, rAAV2 (and rAAV2 variants rAAV2-tYF and rAAV2-7m8), AAV5, and AAV8 have been injected into the human eye (Figure 3A). Evidently more clinical studies will follow with the sharp increase in rAAV clinical trial initiations since 2017. rAAV products moved from a few prototypes towards the use of a more diverse pool of cell-specific native and ubiquitous viral promoters (Figure 3B). Large promoters, such as the CBA/CAG (1661 bp), are less common in recent clinical trial products because of the limited packaging capacity of the rAAV. Now, new products contain relatively small viral or native promoters, such as the ubiquitous viral $\mathrm{CAG} /$ cytomegalovirus (CMV) promoter versions of less than $1 \mathrm{~kb}$ (truncated chimeric CMV/CBA promoter (smCBA); CB-SB; CMV; shortened CMV early enhancer element and a chicken $\beta$-actin promoter (CB7)). These short promoters increase the vector capacity tremendously (see Section 3).

Apart from the promoter and capsid, we searched the literature for enhancers, stabilizing elements (e.g., introns, splice donor/acceptors, Woodchuck hepatitis virus post-transcriptional regulatory element (WPRE)), polyadenylation sequences, pro-viral plasmid backbones, and production platforms. The documentation of this has been neglected in the literature. The enhancers mostly used in the clinical gene therapy vectors were: The cytomegalovirus (CMV) enhancer that is present in CMV and the CBA/CAG promoters and the interphotoreceptor retinoid-binding protein (IRBP) enhancer used in front of the hRS1 promoter (clinical trial NCT02317887). Enhancers can increase the transcription of the transgene (potency) reducing the viral load needed.

Moving on to the introns, common synthetic introns apart from native introns in the gene are rabbit $\beta$-globin intron with splice donor/splice acceptor (SD/SA; in CAG promoter), SV40 intron with SD/SA, human $\beta$-globin intron, and synthetic introns (e.g., $5^{\prime}$-splice donor of the first human $\beta$-globin intron and the $3^{\prime}$-splice acceptor of an intron of the immunoglobulin gene heavy chain variable region; Gene product: ADVM-022). The regulatory element Woodchuck Hepatitis Virus (WHP) Posttranscriptional Regulatory Element (WPRE) was included in 8 products (RST-001; scAAV2-P1ND4v2; GT005; rAAV2-REP1; RetinoStat; rAAV.hCNGA3; UshStat; rAAV2tYF-CB-hRS1; See also Section 3.6). The introns and the posttranscriptional regulatory elements can also increase transgene transcription.

Generally, the main choice for a polyadenylation (polyA) sequence in rAAV vectors are the effective bovine growth hormone (bGH) and the late SV40 polyA sequences (Figure 3C). New short (synthetic) polyadenylation sequences are needed to allow CRISPR/Cas9 constructs to fit in a single rAAV such as in the clinical trial product of Allergan/Editas Medicine Inc to correct the CEP290 
gene in patients (product: AGN-151587/EDIT-101. See Section 3.7 polyadenylation and Section 4.3 CRISPR/Cas9). Today, many clinical trial initiators exist. Some companies efficiently acquired new potential therapies such as MeiraGTx and HORAMA (Figure 3D).
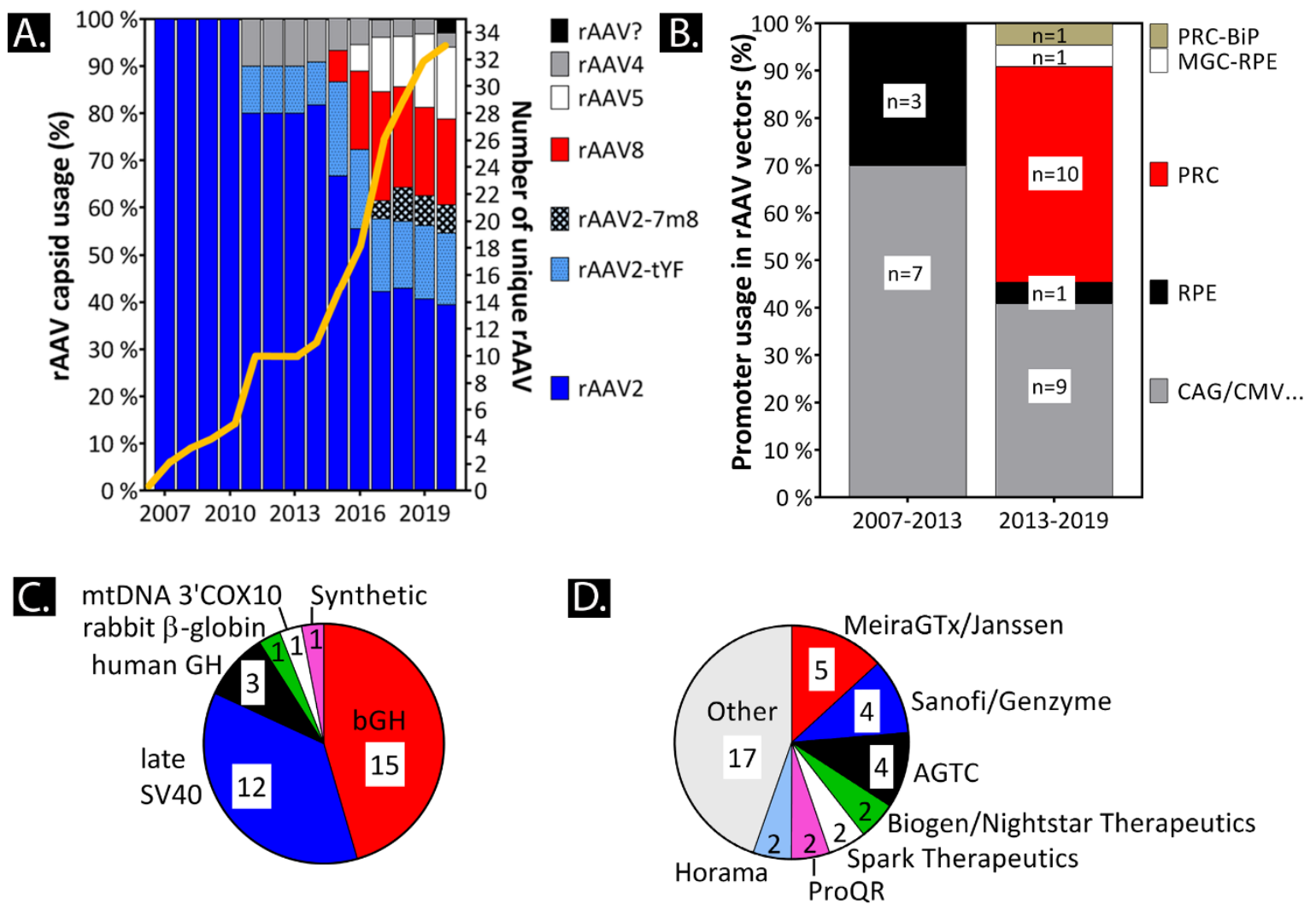

\begin{abstract}
Figure 3. Development of rAAV therapies over the years. (A) Unique rAAV capsids usage over time (\%; $y$-axis left) and unique rAAV treatments (genes) in clinical trials (number; $y$-axis right; Total = 33 of 57 rAAV total clinical trials for the retina). (B) Unique rAAV treatments (genes) and their promoters for the retina (2007-2013 vs. 2013-2019). (C) Unique rAAV treatments (genes) and their polyadenylation sequences in the retina (total $=28$ ). (D) Sponsors with unique rAAV, Lentiviral vector, and AON treatments in clinical trials for the retina/choroid (genes; \%; Total $=38$ ). bGH, bovine growth hormone; CAG/CMV, ubiquitous promoters; late SV40, late Simian Virus; MG, Müller glial cell; RPE, retinal pigment epithelium; PRC-BiP, photoreceptor-bipolar-specific promoter; PRC, photoreceptor-specific promoter; rb $\beta$-globin, rabbit $\beta$-globin polyadenylation sequence.
\end{abstract}

Since relatively little information is provided in the literature, we also compared the different plasmids and production cell lines required to produce rAAVs for clinical trials. Most rAAVs were produced in HEK293(T) cells without the use of helper viruses except for the products tgAAG76 (B50 cell line and helper adenovirus; [39]), rAAV2/2-ND4 (HEK293 infected by HSV1-rc/AUL2; [40]), rAAV2tYF-CB-hRS1/rAAV2tYF-PR1.7- $h$ CNGB3/rAAV2tYF-GRK1-RPGR (sBHK cells infected with rHSV; [41-43]), and ADVM-022 (Baculovirus Sf9; [41]). A list of the pro-viral plasmids of clinical trials can be found in Table S1. A preliminary study investigated if the choice of the production cell line might influence the tropism and potency of the rAAV vector [44]. It showed that the rAAV capsids can have post-translational modifications, such as glycosylation, that depend on the species origin of the production cell. Furthermore, rAAVs produced in a human cell line (HEK293T) compared to baculovirus-Sfg produced rAAVs were more potent in transfecting the liver in mice in vivo and in vitro (HEK293T, Huh7, human induced Pluripotent Stem Cells (hiPSCs), primary human fibroblasts, mouse $\mathrm{C} 2 \mathrm{C} 12$ cells). Further studies will need to address what specifically caused the increase in the transduction efficiency: the post-translational modification, species-dependent impurities in the rAAV 
preparation or the difference in the general production process between HEK293T cells compared to the baculovirus? A more detailed description of pro-viral plasmids for the production of rAAVs for clinical trials is needed to move towards safer plasmids (more information in Section 4.4.1: Production and Table S1).

\section{Discovery of Cell-Specific Promoters for Ocular Gene Therapy}

\subsection{Core Promoters in $r A A V$-Vectors}

Eukaryotic RNA-polymerase II-dependent promoters consist of a core promoter and cis-acting regulatory elements that can include enhancers and silencer motifs [45]. In humans, the cis-acting regulatory domains and core promoters frequently contain cytosine-phosphate-guanosine islands (C:G ratio $>60 \%$ for $>200 \mathrm{bp}$ ). Recent studies indicated that the reduction of $\mathrm{CpG}$ islands in rAAV vectors increased transgene expression and reduced TLR9-mediated innate immune detection [46,47].

Minimal/core promoters require a transcription start site (TSS), a sequence motif for general transcription factors (e.g., TATA-binding protein or TFIIB) directing the binding of the RNA-polymerase II (e.g., $~ 35$-bp upstream positioned TATA/CAAT/GC-box sequence) [45]. Many genes have more than one TSS that are differentially active in tissue and at various developmental stages. Therefore, many rAAV vectors with different promoters are produced and screened on transcription activity in retinal cells. Core promoters are often fused with (predicted) cell-specific enhancer and suppressor fragments. The core promoters of strong ubiquitous promoters (e.g., core CMV [30 bp], SV40mini [106 bp], SCP3 [81 bp] Table 2) have been extensively used in promoter element library screens [48-50].

\subsection{Ubiquitous Promoters in $r A A V$-Vectors}

Most of the promoters used in rAAV vectors are unidirectional ubiquitous promoters such as the cytomegalovirus early enhancer/cytomegalovirus promoter (CMV), the minimal CMV promoter $(\sim 300 \mathrm{bp})$, the cytomegalovirus early enhancer/chicken $\beta$-actin promoter (CBA aka CB7; $800 \mathrm{bp}$ ), the cytomegalovirus immediate-early enhancer/chicken $\beta$-actin promoter/rabbit $\beta$-globin intron (CAG or CAGGS or CBA), the human phosphoglycerate kinase (PGK) promoter, and the elongation factor-1 alpha (EF-1 $\alpha$ ) promoter [51-55]. The CAG, CMV, and CBA promoters outperform the EF-1 $\alpha$ and PGK in total expression in the retina [54]. Smaller derivatives of the promoters have been developed with comparable expression patterns in some but not all tissues, such as the CMV/CBA-derivative CMV early enhancer with the chicken $\beta$-actin promoter with a chimeric chicken $\beta$-actin minute virus of mice (MVM) viral capsid protein (VP1) intron (CBh; 800 bp), the CBA-derived CMV early enhancer with the chicken $\beta$-actin promoter and a truncated SV40 late $16 \mathrm{~S}$ intron (CBA aka CB7, $\sim 800 \mathrm{bp}$ ), and the minimal CMV promoter ( 260 bp [24]; see Table 2$)$. However, several ubiquitous promoters are silenced in specific cell types and tissues. For example, the CMV promoter had a sharp onset of expression but was silenced compared to the CBh promoter over ten weeks when expressed in the hippocampus, the spinal cord, or the substantia nigra. In contrast, the CMV promoter was not silenced in the striatum [54,56-58]. The role of CMV cis-regulatory silencing in the retina is less established. Administration of CMV.eGFP DNA incorporated into nanoparticles showed robust expression in the retina after two days, but the expression was not detectable after two weeks [59]. We have found protein expression (GFP, CRB1, or CRB2) in photoreceptors after one to three months of rAAV vector administration in wild-type and CRB1-related retinitis pigmentosa mouse models [24,60]. SpCas9 was also detected in retinal flat mounts in mice two weeks post-subretinal injection of the rAAV-CMV.spCas9 [61]. Similarly, the expression of GFP was detected after two to four weeks in human iPSC-derived retinal organoids transduced with rAAV-CMV-eGFP vectors [62]. The studies described above indicate that the ubiquitous CBA and CMV promoters are most likely less affected by the retinal disease state or cellular differentiation status. 
Table 2. Common ubiquitous promoters for rAAV-based ocular gene therapies.

\begin{tabular}{|c|c|c|c|}
\hline Ubiquitous Promoters & Size (bp) & Origin, Cell Expression, Strength & References \\
\hline $\begin{array}{l}\text { CAGGS aka CBA } \\
\text { or CAG }\end{array}$ & 1600 & $\begin{array}{l}\text { Ubiquitous, }+++ \text {. Cytomegalovirus immediate-early } \\
\text { enhancer, chicken } \beta \text {-actin promoter, chimera } \\
\text { between introns from chicken } \beta \text {-actin and rabbit } \\
\beta \text {-globin. pDRIVE CAG plasmid (Invivogen, San } \\
\text { Diego, Calif.; having } 100 \% \text { sequence homology with } \\
\text { the pCAGGS). The University of Pennsylvania } \\
\text { considers CBA and CAGGS the same. }\end{array}$ & [63] \\
\hline mini CAG (SV40 Intron) & 800 & Ubiquitous, +++ & [64] \\
\hline Mini CAG no intron & 250 & chicken $\beta$-actin promoter, Ubiquitous, + & [57] \\
\hline $\mathrm{CBA} / \mathrm{CB} 7$ & 800 & Ubiquitous, ++ & [65] \\
\hline smCBA & 953 & Ubiquitous, ? & [66] \\
\hline $\mathrm{CBh}$ & 800 & CBA.MVM Ubiquitous, ++ & {$[54,67]$} \\
\hline $\mathrm{MeCP} 2$ & 229 & ubiquitous & [68] \\
\hline $\mathrm{CMV}$ & 800 & Ubiquitous, ++ , prone to silencing & [54] \\
\hline shCMV & 220 & Ubiquitous, ++ & [24] \\
\hline CMVd2 & 52 & Low basal activity. Ubiquitous, Promega, + & $\begin{array}{c}\text { [69] Cat.: pFN23A Halo } \\
\text { Tag CMV d2 }\end{array}$ \\
\hline core $\mathrm{CMV}$ & 30 & Not active without enhancers & [48] \\
\hline SV40mini & 106 & SV40 minimal promoter & {$[48,49]$} \\
\hline $\mathrm{SCP} 3$ & 81 & Super core promoter. (TATA box, Inr, MTE and DPE) & [48] \\
\hline EF1- $\alpha$ & 2500 & Ubiquitous, ++ & {$[51,70]$} \\
\hline PGK & 426 & Ubiquitous, ++ & [53] \\
\hline $\mathrm{UbC}$ & 403 & Ubiquitous, ++ & {$[70]$} \\
\hline
\end{tabular}

\subsection{Bicistronic and Tricistronic Promoters in $r A A V$-Vectors}

Expression of two or more genes in a gene therapy vector can be achieved with an Internal Ribosomal Entry Sequence (IRES; non-read through linker), or otherwise, at least two different promoters could be used. The promoters could drive the expression of multiple genes with a fusion protein linker (e.g., (Gly $\left.{ }_{4} \mathrm{Ser}\right)_{2}$ spacers ( $\sim 30 \mathrm{bp}$; read through linker), or a sequence encoding self-cleaving peptides (T2A, P2A, E2A, F2A; 30-75 bp; read-through linkers) between the gene sequences. Fusion proteins can, however, alter the function of some of the proteins. The cleavage efficiency of genes connected with self-cleaving peptide sequences varies. Moreover, self-cleaving peptide sequences add additional amino acids that stay attached to the protein product. Moreover, several genes from one promoter connected with a linker generally reduce the expression of each subsequent gene. Nevertheless, researchers demonstrated the feasibility to mediate expression by a single promoter of three different genes (for example, Oct4, Sox2, and Klf4) connected with self-cleaving peptide sequences in a rAAV9 expression vector upon transduction of ganglion cells. The rAAV9-Oct4/Sox2/Klf4 expression vector rescued ganglion cell survival in an optic nerve crush mouse model [71].

The interspersing IRES (572 bp) or minimum IRES (436 bp) allows efficient expression of independent genes into cap-independent RNA transcripts [72]. Yet, studies indicate a decrease in protein production of the protein-coding DNA located behind the IRES compared to the use of a conventional promoter. Adding a spacer $(\sim 30-90 \mathrm{bp})$ in the inter-cistronic sequence can enhance the IRES-dependent translation of the second gene [73,74]. Many different IRES exist that have been extracted from different viruses, such as in the family of the picornaviridae. Placing two promoters in opposing directions next to each other also allows efficient bicistronic gene expression from one gene cassette [75]. Bi- or tricistronic rAAV gene cassettes are especially useful where the protein of interest (e.g., Cre-recombinase) is expressed in a specific cell type together with an internal marker (e.g., for reporter gene assays), or when studying retinal circuits (e.g., by calcium imaging), or when performing rAAV-retrograde labeling [52,76-79]. 
Bicistronic rAAV gene cassettes hold the key to supplement a wild-type transgene and removing disease-causing variant proteins in an all-in-one rAAV vector therapy. For example, in autosomal recessive retinal disease, ocular gene augmentation therapies express a functional gene in retinal cells that lack a functional copy of that same gene. However, in autosomal dominant (e.g., rhodopsin) or X-linked dominant (e.g., some variations in RPGR) retinal diseases, the allele bearing the dominant-negative variation needs to be ideally inactivated. Some dominant diseases do respond positively to gene augmentation, but inactivation might further slowdown vision loss. Such inactivation can be achieved, for example, by gene editing or small interfering RNA to allow gene augmentation therapy to work. In the latter case, to prevent inhibition of the newly introduced gene, codon-optimization of the transgene might prevent inactivation by the gene-editing or siRNA tools used [80]. Here, an rAAV vector expressing a wild-type RPGR transgene and downregulation of the mutant RPGR transgene could benefit patients.

Similarly, many inherited retinal diseases benefit from the administration of cell survival factors [81-85]. The expression of cell survival factors, such as the basic fibroblast growth factor (bFGF; $470 \mathrm{bp}$ ), ciliary neurotrophic factor (CNTF; $600 \mathrm{bp}$ ), glial cell line-derived neurotrophic factor (GDNF; $511 \mathrm{bp}$ ), pigment endothelial-derived factor (PEDF; $883 \mathrm{bp}$ ) and brain-derived neurotrophic factor (BDNF; $750 \mathrm{bp}$ ) can be expressed concomitantly with the gene-of-interest boosting the treatment effect $[86,87]$. Combining a gene supplementation therapy with a supporting factor expressed from one $\mathrm{AAAV}$ vector is very promising for future treatments.

\subsection{Retina-Specific Promoters}

The use of these native occurring regulatory sequences may actively modulate transcription and thereby preventing overexpression. A native promoter could, therefore, potentially reduce toxicity due to overexpression of the transgene. Cellular toxicity can, for example, be observed in rAAV shRNA overexpression studies in which ubiquitous promoters were used that caused saturation of cellular miRNA pathways [88].

Many retinal cell-type-specific promoters have been developed (Table 3). The selection and validation of tissue-specific promoters can be complicated and time-consuming. Many tissue-specific promoters in mice turned out to be less specific in human or non-human primates [50]. Further, many tissue-specific promoters drive much lower gene expression, compared to the CBA/CMV/CAG ubiquitous promoters. Nevertheless, many tissue-specific promoters can efficiently express many transgenes from rAAV-gene cassettes: NA65p (RPE cells), Nefh (ganglion cells), hGRK1 (rod and cone photoreceptor cells), hRLBP1 (Müller glial cells and RPE cells) and others [24,36,89-91]. For an extensive list, see Table 3. cDNA codon-optimization and the inclusion of introns (e.g., MVM, SV40) and enhancers (e.g., CMVe, IRBPe, Grm6e) to tissue-specific promoters can substantially increase the promoter activity (see Section 3.6). For example, the NA65p promoter is derived from the hRPE65p but now has a 150 $\times$ higher potency than the CBA in mice [36]. The optimized promoter may become useful to efficiently express transgenes (e.g., CRISPR/Cas) in the normal retina, but it is not yet proven that the promoter works as good in the diseased human retina. The promoter might be less active or overactive in diseased retinal target cells that express the required transcription factors at other levels than in the normal retina.

Cell-specific promoter activities are inherently difficult to predict how they will fare in disease states when the pool of transcription factors in a cell change. Many viral promoters evolved to maximize the survival of the virus in different cellular contexts. Several viral promoters exhibit expression in many cell types in various cell "states" (stressed, developmental state, cell cycling). For example, the transactional activation of the widely used CMV or early SV40 promoters is related to the binding of the ubiquitous transcription factors Sp1/Sp3 [92,93]. Moreover, most mammalian cells express the Sp1 transcription factor [94]. Adding the CMV immediate-early enhancer (CMVe or CE) to cell-specific promoters generally increases expression but may also decreases specificity (see Table 4). 
Unfortunately, many tissue-specific promoters are too large to fit into rAAV vectors. Fitting depends on the size of the gene of interest, which is why many promoters are further shortened and optimized for cell-type-specific expression. We reduced the length of a Müller glial cell-specific CD44 promoter from $1775 \mathrm{bp}$ to $363 \mathrm{bp}$ but then abandoned the shortened CD44 promoter because of a substantial loss of expression in vivo [24,95]. The full-length glial fibrillary acidic protein (GFAP) promoter $(2789 \mathrm{bp})$ showed excellent Müller glial specific gene expression in human retinal organoids and human retinal explants [24,62]. Furthermore, a shortened version of the GFAP promoter called gfaABC1D (686 bp) showed similar expression strength in neurons (brain), whereas the gfaABC1D promoter maintained Müller glial cell-specific expression in the retina $[96,97]$. We compiled a list of relatively short promoters that have been at least tested in the mouse retina (Table 3). The list might allow to further find enhancer elements to generate novel short, specific, and strong promoters for ocular gene therapies.

Table 3. Retina cell-specific promoters in rAAVs for ocular gene therapy.

\begin{tabular}{|c|c|c|c|}
\hline Müller Glial Cells & Size (bp) & Origin, Cell Expression, Strength & References \\
\hline CHX10 & 164 & Retinal progenitor cells & [98] \\
\hline GFAP & 2600 & Müller glial cells, & {$[99,100]$} \\
\hline GFAP & 2200 & Müller glial cells (Novartis) & [101] \\
\hline GfaABC1D & 686 & Müller glial cells & {$[96,97]$} \\
\hline HRSE-6xHRE-GfaABC1D & $\sim 820$ & $\begin{array}{l}\text { Hypoxia-induced reactive MGC promoter. } \\
\text { HRE is (A/G)CGT(G/C)C. HRSE from } \\
\text { metallothionein II promoter ( } 90 \mathrm{bps})\end{array}$ & {$[97,102]$} \\
\hline RLBP1 & 2789 & Müller glial cells & {$[24,89]$} \\
\hline Short RLBP1 & 581 & Müller glial cells & [101] \\
\hline Murine CD44 & 1775 & Müller glial cells & {$[24,95]$} \\
\hline Murine shCD44 & 363 & Müller glial cells & {$[24,103]$} \\
\hline ProB2 & 592 & Müller glial cells & {$[50]$} \\
\hline Photoreceptor Cells & Size (bp) & Origin, Cell Expression, Strength & References \\
\hline Mouse RHO & 1400 & Rod PRCs & [104] \\
\hline Human RHO (rhodopsin) & 800 & Rod PRCs & [105] \\
\hline Human RHO & 520 & Rod-PRCs & {$[24]$} \\
\hline Mouse rod opsin mOp500 & 500 & $\begin{array}{l}\text { Rod-PRCs } \\
-385 /+86\end{array}$ & [106] \\
\hline Mouse rod opsin & 221 & Rod-PRCs & [107] \\
\hline $\begin{array}{l}\text { Human Rhodopsin kinase } \\
\text { (RHOK/GRK1) }\end{array}$ & 294 & $\begin{array}{l}\text { Rod and cone PRCs. AY327580.1: bp } \\
\text { 1793-2087 ( }-112 \text { to }+180) \text {. More efficient } \\
\text { than IRBP in NHP for cone transduction }\end{array}$ & {$[24,91,108-110]$} \\
\hline Human blue opsin HB570 & 570 & S-cone and subset of M-cones PRCs & [111] \\
\hline Human blue opsin HB569 & 569 & blue cone opsin PRCs & {$[106,112]$} \\
\hline PR0.5 & 496 & Red cone PRCs & [106] \\
\hline PR1.7 & 1700 & Red cone PRCs & [106] \\
\hline PR2.1 & 2100 & Red cone PRCs & [106] \\
\hline 3LCR-PR 0.5 & $\sim 600$ & Red cone PRCs & [106] \\
\hline Mouse blue opsin (mBP500) & 500 & Mouse S opsin & [113] \\
\hline $\begin{array}{l}\text { Human interphotoreceptor } \\
\text { retinoid binding protein } \\
\text { (hIRBP) }\end{array}$ & 235 & $\begin{array}{c}\text { Cone and rod PRCs } \\
\text { X53044.1, bp 2603-2837 }\end{array}$ & [114] \\
\hline IRBPe/GNAT2 & 500 & Cone PRCs & [115] \\
\hline Mouse CAR/ARR3 & 500 & Cone PRCs, some rods, and RPE & [115] \\
\hline Human CAR/ARR3 & $405-500$ & Cone PRCs, some rods, and RPE cells & {$[115,116]$} \\
\hline CAR/ARR3 & 215 & Cone PRC & [117] \\
\hline Human red opsin & 2100 & Human red cone opsin & [118] \\
\hline $\begin{array}{l}\text { Human green red opsin } \\
(\mathrm{G} 1.7 \mathrm{p})\end{array}$ & 1700 & $\begin{array}{l}\text { Cone PRCs. Core green opsin promoter } \\
\text { including a mutation }(0.5 \mathrm{~kb})+\text { Locus } \\
\text { Control Region (LCR; } 1.2 \mathrm{~kb}) \text { upstream of } \\
\text { the red opsin gene }\end{array}$ & [119-121] \\
\hline Crx2kb & 2000 & Cone and rod PRCs & [122] \\
\hline ProA1 & 2000 & cone PRCs & {$[50]$} \\
\hline ProA4 & 2000 & cone PRCs & {$[50]$} \\
\hline ProC1 & 731 & Cone and rod PRCs & [50] \\
\hline $\begin{array}{l}\text { ProA6,ProB5,ProC22, } \\
\text { ProC32,ProD2,ProD3, } \\
\text { ProD4,ProD5,ProD6 }\end{array}$ & $\begin{array}{c}1229,619 \\
774,814 \\
366,691 \\
552,321,448\end{array}$ & rod PRCs & [50] \\
\hline Synp161 & 150 & $\begin{array}{l}\text { Mouse CD47 enhancer + SV40-mini } \\
\text { promoter. Rod PRCs }\end{array}$ & [49] \\
\hline
\end{tabular}


Table 3. Cont.

\begin{tabular}{|c|c|c|c|}
\hline Bipolar Cells & Size (bp) & Origin, Cell Expression, Strength & References \\
\hline $\begin{array}{l}\text { Mouse metabotropic } \\
\text { glutamate receptor } 6 \\
(\mathrm{mGrm})\end{array}$ & 200 & On-bipolar cells & [98] \\
\hline $4 \times$ mGRM6e+SV40 & 1000 & $\begin{array}{l}\text { On-bipolar cells. } 203 \mathrm{bp} \text { SV40 minimal } \\
\text { promoter }\end{array}$ & [123] \\
\hline Grm6e-Chx10-Cabp5 & 809 & $\begin{array}{c}200 \text { bp Grm6 }+164 \text { bps Chx10 enhancer + } \\
445 \text { bp Cabp5 promoter. Wide overlapping } \\
\text { bipolar expression }\end{array}$ & [98] \\
\hline Grm6-SV40 & 400 & $\begin{array}{c}\text { Grm6 }=\text { mGluR6. } 200 \mathrm{bp} \text { mGluR6 enhancer }+ \\
\text { SV40 promoter. On-Bipolar cells }\end{array}$ & [98] \\
\hline Cabp5 & 445 & Bipolar cells & [98] \\
\hline Chx10-SV40 & 364 & $\begin{array}{c}164 \text { bp Chx10 enhancer + } 200 \text { bp SV40 } \\
\text { promoter. Bipolar cells and Müller glial } \\
\text { cells }\end{array}$ & [98] \\
\hline Grm6-mGluR500P & 700 & On-bipolar cells. & [124] \\
\hline In4s-In3e- Grm6-mGluR500P & 1997 & $\begin{array}{c}690 \mathrm{bp} \text { shortened Intron } 4 \mathrm{~s}+807 \mathrm{bp} \text { Intron } \\
3+500 \mathrm{bp} \text { mGluR500P }\end{array}$ & [124] \\
\hline ProB4 & 1317 & Off-bipolar cells & [50] \\
\hline Amacrine Cells & Size (bp) & Origin, Cell Expression, Strength & References \\
\hline ProC2 & 964 & All amacrine cells + few MGCs & [50] \\
\hline ProB1 & 394 & Amacrines with processes in one stratum & [50] \\
\hline Horizontal Cells & Size (bp) & Origin, Cell expression, Strength & References \\
\hline ProC3 & 694 & $\begin{array}{l}\text { Some off-target in amacrine and ganglion } \\
\text { cells }\end{array}$ & [50] \\
\hline Retinal Ganglion Cells & Size (bp) & Origin, Cell expression, Strength & References \\
\hline Syn1 & 495 & Off target amacrine, strength: ++ & [125] \\
\hline Nefh & 2251 & Strength: +++ & {$[90]$} \\
\hline hSNCGp & 948 & $\begin{array}{l}\text { Human SNCG promoter ( }-785 \text { to }+163 \\
\text { region) }\end{array}$ & {$[126]$} \\
\hline ProA3 & 2000 & Synthetic & [50] \\
\hline Ple344 & 801 & Gene TUBB3. GCL and corneal nerves. ++ & [127] \\
\hline Ple345 & 2693 & Gene NEFL. +++ (stronger than smCBA) & {$[127]$} \\
\hline RPE & Size (bp) & Origin, Cell Expression, Strength & References \\
\hline hRPE65p & 1383 & $\begin{array}{c}\text { Chr1.68449936-68451318. RPE+ some PRC } \\
\text { infection }\end{array}$ & [128] \\
\hline NA65p & 1383 & $\begin{array}{l}\text { Codon optimized hRPE65p+SV40 intron }+ \\
\text { Kozak seq, } 150 \times \text { more efficient than CBA } \\
\text { and 300× more efficient than hRPE65p }\end{array}$ & [36] \\
\hline VMD2 & 646 & NG_009033.1, bp 4870-5516 & {$[126,129]$} \\
\hline Synpiii & 1317 & + SV40 mini promoter & [130] \\
\hline
\end{tabular}

\subsection{Small Nuclear RNA (snRNA) Promoters}

RNA polymerase (RNAP)-dependent regulatory promoters (U1, U2, U6, U7, H1; 250 bp) can be used to drive short hairpin RNAs (shRNAs). The human U6 promoter is a potent promoter that has been widely used for the expression of shRNAs. However, the relatively large size, the requirement that the transcript starts with a $\mathrm{G}$ or $\mathrm{A}$, the sometimes too active transcription, and the sensitivity to specific cellular profiles make the human U6 promoter a less versatile promoter $[88,131,132]$. RNA polymerase III promoters also have been re-engineered with CMV enhancers [133] or tissue-specific enhancers (heart, muscle) for siRNA expression [134]. The tissue-specific enhancers increased expression but were less tissue-specific.s Single guide RNAs (gRNA) are typically expressed by a U3 or U6 RNA promoter in rAAV gene cassettes. Relative tissue-specific expression of two gRNAs for CRISPR/Cas gene editing in myotubes was achieved by linking a muscle-specific MHCK7 promoter (pol II) with gRNA-linked self-cleaving ribozyme sequences derived of Hepatitis delta virus (HDV) and a Hammerhead (HH) sequence [134-137]. The research for promoters for tissue-specific expression from a small nuclear RNA promoter is an underrepresented field. More promoters to choose from would increase the number of genes that target for ocular gene therapy. Currently, many gRNA rAAV gene cassettes circumvent the lack of snRNA cell-specific promoters by driving the expression of the gRNA from ubiquitous snRNA but the Cas 9 from a cell-specific promoter (see Section 4.3 for examples). 


\subsection{WPRE, Introns, miRNAs, and Other Elements in a rAAV-Gene Cassette}

Post-transcriptional regulatory elements (PRE) can substantially increase gene expression. Woodchuck posttranscriptional regulatory element (WPRE; 600 bp) or Hepatitis B Virus Posttranscriptional Regulatory Element (HPRE; $533 \mathrm{bp}$ ) increase the transgene expression up to 6-9 times [57]. The addition of a WPRE also protects from silencing in human ES cells and the brain. To validate the use of WPRE for retinal gene therapy, rAAV2/2.CMV.eGFP.pA vectors with or without WPRE were applied to human retinal explants or injected in mouse eyes [138]. A shorter version of the WPRE (WPRE3; $247 \mathrm{bp}$ ) showed only a 15\% drop in expression in hippocampal neuron cultures or GFP expression in rAAV infected hippocampal CA1 region in the mouse brain [139]. A modified WPRE version that removed any viral protein expression has been patented for retinal use [140]. WPRE might be redundant if used in combination with a promoter containing introns. No increase in transgene expression was found when added to the CAG or EF- $1 \alpha$ indicating that a maximum of transcriptional activity and quality can be reached by having good regulatory elements found in certain promoters containing introns or in the WPRE $[75,141]$. Inclusion of natively occurring or synthetic introns can strongly boost protein expression, especially for vectors with low efficiency of gene splitting sites [142]. Many introns have been developed for rAAV gene cassettes that can enhance the gene expression (Table 4). Especially, the strong MVM intron-1 of the viral capsid protein (VP-1) of only 67-to-97 bp can increase the transcript expression by $10 \times$ [143]. Moreover, the development of minicircle rAAVs has contributed to novel introns that are placed in the backbone of pro-viral plasmids to boost production yield. This strategy will be discussed further under section production [144].

Adding microRNAs (miRNA, $18-25$ bp) can alternatively be used to prevent the ectopic expression of the transgene in ocular gene therapy. Adding $4 \times$ the complementary sequence of miRNA204 to a rAAV2/5.CMV.eGFP.WPRE.4xmiRNA204T significantly reduced eGFP expression in RPE cells after subretinal injection in mice and pigs. Similarly, adding $4 \times$ the complementary sequence of miR-124 removed the expression in photoreceptors [145]. Furthermore, a dual-acting rAAV2/5 vector expressed the miRNA $(5, B, 7)$, against Vascular endothelial growth factor A (VEGFA) and antiangiogenic protein pigment endothelial-derived factor (PEDF) driven by an RPE-specific Bestrophin 1 (VMD2) promoter, suppressed choroidal neovascularization in a wet-AMD mouse model [87]. However, the oversaturation of the cognate miRNA needs to be considered when using miRNAs, because they can decrease the function of native miRNAs in the cell. $4 \times$ miRNA placed in an rAAV-CMV expression cassette generally is sufficient for miRNA expression without inducing side-effects [145]. Others have used miRNAs to inhibit transgene expression in antigen-presenting cells (APCs) with miR-142-3p [146]. Still, short hairpin DNA sequences need to be placed at least proximal to the second ITR and be tested for possible rAAV genome truncation for proper expression of the short hairpin RNA (shRNA). Short-hairpin DNA can effectively truncate rAAV genomes during production and produce non-intact shRNA expression cassettes [147]. A more detailed review of miRNAs can be found here [148]. 
Table 4. Other elements in rAAV vectors: A. Introns, PRE, and enhancers. B. Miscellaneous.

\begin{tabular}{|c|c|c|c|}
\hline Introns and PRE and Enhancers & Size & Description, Strength & References \\
\hline CE (CMV early enhancer) & 431 & $\begin{array}{c}+++, 1.5-67 \times \text { increase; }-118 /-522 \text { TSS } \\
\text { pCMV } \beta / 5^{\prime} \text { CMV enhancer }\end{array}$ & [149] \\
\hline IRBPe & 235 & $\begin{array}{l}\text { human interphotoreceptor retinoid-binding } \\
\text { protein proximal enhancer. Upstream nt } \\
\qquad-1619 /-141 \text { IRBP }\end{array}$ & [115] \\
\hline $\begin{array}{c}\text { metabotropic glutamate receptor } 6 \\
\text { enhancer (Grm6e) }\end{array}$ & 200 & Grm6 proximal enhancer & [98] \\
\hline $\begin{array}{l}\text { Woodchuck Hepatitis Virus PRE } \\
\text { (WPRE) }\end{array}$ & 600 &,$+++ 6-10 \times$ increase & {$[139,150]$} \\
\hline Hepatitis B Virus PRE (HPRE) & 533 &,$+++ 6-10 \times$ increase & [150] \\
\hline WPRE3 & 247 &,$++ 6 \times$ increase & [139] \\
\hline MVM & $67-97$ & $\begin{array}{l}+++, \text { minute virus of mice, } 10 \times \text { increase } \\
\text { Chimeric CMV }(146 \mathrm{bp})+\text { human }\end{array}$ & [143] \\
\hline chCMV.HBB2 & $\sim 506$ & $\begin{array}{c}\beta \text {-globulin intron } 2(340 \mathrm{bp})+\text { exon } 320 \mathrm{bp} \\
\text { incl SA/SD }\end{array}$ & [151] \\
\hline Hybrid adenovirus $\mathrm{SD}^{\#} / \mathrm{IgG} \mathrm{Sa}{ }^{*}$ & 230 & $+++, p \operatorname{Ad} \beta, 2 \times$ increase to synthetic polyA & [149] \\
\hline SV40 late SD $/$ Sa* $^{*}(19 S / 16 S)$ & 180 & $\begin{array}{l}+, \text { pCMV } \beta \text { (Promega; } 1.6 \times \text { increase) } \\
\text { modSV40 SA/SD= modified SV40 splice } \\
\text { acceptor/donor intron, } 157 \text { bp in length, }\end{array}$ & [149] \\
\hline Modified SV40 SD ${ }^{\#} \mathrm{Sa}^{*}$ & 157 & $\begin{array}{c}\text { nucleotides } 502-561 \text { and } 1410-1497 \text { of SV40 } \\
\text { genomic sequence (NC_001669.1) + } \\
\text { connecting sequence CGGATCCGG } \\
\text { between two fragments. }\end{array}$ & {$[101,152]$} \\
\hline Mini SV40 SD ${ }^{\#} / \mathrm{Sa}^{*}$ & 100 & Mini SV40 $S^{\#} / \mathrm{Sa}^{*}$ intron & {$[43,153,154]$} \\
\hline Human $\beta$-globin intron $2 \mathrm{SD}^{\#} / \mathrm{Sa}^{*}$ & 875 & $0.5-86$-fold increase. pZac2.1 & {$[139,155-157]$} \\
\hline F.IX truncated intron 1 & 300 & +, human factor IX (100×) & {$[143,158]$} \\
\hline Miscellaneous & Size & Description & References \\
\hline $2 \mathrm{~A}$ & 75 & Self-cleaving linker & [159] \\
\hline $\begin{array}{l}\text { internal ribosomal entry site } \\
\text { (IRES) }\end{array}$ & 600 & $\begin{array}{l}\text { Ubiquitous. Placed between two genes. } \\
\text { The second gene is transcribed without a } \\
\text { promoter (at a lower expression compared } \\
\text { to the first gene) }\end{array}$ & [160] \\
\hline SPTP & 154 & $\begin{array}{l}\text { Synthetic polyA signal/transcriptional } \\
\text { pause site frp, pGL4.25 }\end{array}$ & [161] \\
\hline PolII miR-155 & $\sim 500$ & $\begin{array}{c}\text { Block-iT PolII miR vector system based on } \\
\text { miR-155 expressing artificial miRNAs } \\
\text { engineered to a target sequence resulting in } \\
\text { target cleavage }\end{array}$ & [162] \\
\hline shRNA-YB1 & N/A & $\begin{array}{l}\text { 7-to-45 fold AAV production increase in } \\
\text { physical titer }\end{array}$ & [163] \\
\hline MIP backbone & N/A & $\begin{array}{l}\text { mini-intronic plasmid (MIP) backbones for } \\
\text { AAV production increased transgene } \\
\text { expression by } 40-100 \text { fold in vivo }\end{array}$ & [144] \\
\hline R6K & 545 & $\begin{array}{c}+(\sim 40 \times), \mathrm{pUC}+\text { prokaryotic RNA-OUT } \\
\text { antibiotic-free, minicircle AAVs }\end{array}$ & [144] \\
\hline OIPR & 1300 & $\begin{array}{l}+(\sim 40 \times), \mathrm{pUC}+\text { prokaryotic RNA-OUT } \\
\text { antibiotic-free, minicircle AAVs }\end{array}$ & [144] \\
\hline Shorter OIPR & 500 & $\begin{array}{l}+(\sim 5 \times), \mathrm{pUC}+\text { prokaryotic RNA-OUT } \\
\text { antibiotic-free, minicircle AAVs }\end{array}$ & [144] \\
\hline
\end{tabular}

The relative strength (+ being the weakest and +++ being the strongest). Adapted from $[7,57,164]$.

\subsection{Polyadenylation Sequences in $r A A V-G e n e$ Cassette}

To allow for efficient pre-mRNA processing, an efficient polyadenylation sequence needs to be included behind the transgene to form a proper poly(A) tail at the RNA's $3^{\prime}$ end. Polyadenylation sequences in rAAVs gene cassettes are listed in Table 5 and include for example SV40 late (135 bp; $+++)$, bGHpolyA $(250 \mathrm{bp} ;++)$, synthetic polyadenylation $(\mathrm{spA})+2 \times$ SV40 late upstream elements (100 bp,++$), 2 \times$ sNRP1 (34 bp,$+/++)$, synthetic polyA (spA; 49-60 bp,+ ), hGHpolyA (624 bp, +), 1× sNRP1 $(17 \mathrm{bp},+)$, and adenovirus L3 $(21 \mathrm{bp},+)$ polyadenylation sites $[57,165]$.

Recent developments allow for shorter and more potent expression cassettes. The SV40 late polyadenylation signal upstream element and the SV40 late polyadenylation signal combined with the 
WPRE3 (420 bp), decrease the length to less than half compared to the commonly used WPRE-bGHpolyA gene cassette (919 bp), and maintain a similar expression profile [139]. The removal of a WPRE sequence reduced the expression by $80 \%$, whereas the use of a synthetic polyadenylation sequence $(49 \mathrm{bp})$ in combination with two SV40 late upstream elements (50 bp) increased the GFP expression compared to the use of a robust bGHpolyA sequence. Interestingly, the interplay of the polyadenylation sequence with transcriptional regulation enhancers can increase transcript levels. However, the effect can be quite specific to elements. For example, paring a CMV $\beta$ enhancer with an SV40 polyA increased transcript levels but the CMV $\beta$ enhancer paired with a bGHpolyA did not [149].

Also, the rAAV gene cassette for hemophilia $B$ was tested with different polyadenylation sequences. The bGHpolyA turned out to be the strongest for the FIX gene expression, outperforming other polyA sequences such as the synthetic polyA, mouse $\beta$-globin $\mathrm{pA}$, rabbit $\beta$-globin $\mathrm{pA}$, and H4-based pA [143]. Studying polyadenylation sequences can be very valuable for rAAV gene cassette size reduction. Notably, a 17-bp soluble neuropilin-1 (sNRP-1) polyA sequence efficiently expressed transgenes on infection of an rAAV vector. When the sequence was used twice ( $2 \times$ sNRP-1 polyA), then the potency was as efficient as a single SV40polyA sequence $[165,166]$. Yet, the two sNRP-1 polyA were less suitable for specific transcripts compared to bGHpolyA or spA [167]. The effects of polyadenylation sequences for specific transcripts are still less well understood. For example, whereas polyA's increase transcript stability/expression, certain polyadenylation sequences can also reduce viral titers during rAAV particle production [168]. Thus, different polyadenylation sequences should be tested for optimal gene expression and virus production.

Table 5. Polyadenylation sequences.

\begin{tabular}{|c|c|c|c|}
\hline Polyadenylation & Size & Description, Strength & References \\
\hline SV40 late & 135 & +++ & [139] \\
\hline $2 \times$ SV40 late & 100 & $++/+++$ & {$[169]$} \\
\hline bGHpolyA & 250 & ++ & [149] \\
\hline $2 \times$ sNRP1 & 34 & $+/++$ & [167] \\
\hline Rabbit gbpA & 56 & Rabbit $\beta$-globin & [149] \\
\hline $\mathrm{spA}$ & 49 & $+/++(7 \times$ lower than bGHpolyA, $3 \times$ lower than SV40 late $)$ & {$[139,149]$} \\
\hline hGHpolyA & 624 & + & {$[41,170,171]$} \\
\hline $1 \times \mathrm{sNRP} 1$ & 17 & + & [167] \\
\hline HSV TK poly(A) & 48 & $\begin{array}{c}\text { herpes simplex virus (HSV) thymidine kinase (TK) } \\
\text { polyadenylation signal. Generally used for NeoR and } \\
\text { KanR genes }\end{array}$ & [172] \\
\hline Adenovirus (L3) USE & 21 & + & [169] \\
\hline
\end{tabular}

The relative strength (+ being the weakest and +++ being the strongest). Modified from $[7,57,164]$.

\section{8. rAAV Vector Cassettes and Inducible Promoters}

Many gene supplementation therapies rely on constant overexpression of the therapeutic gene. The constant active expression increases the risk that the rescue vector itself becomes toxic to the cell. Stress (GFAP promoter) or hypoxia-driven GFAP promoters (HRSE-6xHRE-GfaABC1D) have been generated that might be safer for cells that are sensitive to continuous overexpressed artificial gene vectors $[96,97,99,100,102]$. Other inducible On/Off gene expression systems have been described: Tetracycline (Ptet), dihydrofolate reductase (DHFR) protein destabilizing domains, riboswitches, metal activated promoters (metallothionine-Ia; MT-1), and hormone-activated promoters (dexamethasone, MMTV LTR. Table 6) [173-176]. All but the riboswitches require the expression of an exogenous (bacterial) protein. The TET-system is activated by an antibiotic (tetracycline or doxycycline), making it suboptimal for human use. An example of an efficient TET-off rAAV system is an rAAV expression cassette that includes $6 x$ the mutated tetracycline response elements (TRE; $200 \mathrm{bp}$ ) placed in front of a minimal promoter (CMV; $\sim 40 \mathrm{bp}$; total cistronic size: $\sim 270 \mathrm{bp}$ ). Upon rAAV infection of the cell, then the ubiquitous promoter $\mathrm{UbC}$ will drive the transactivator reverse tetracycline transactivator 3 (rtTA3), making it a Tet-on system. Upon Cre recombinase expression, the rtTA3 is floxed-out, rendering the expression vector to a Tet-off system. The rtTA3 binds to the TRE in the presence of doxycycline, 
starting the expression of the TurboRFP open reading frame (ORF) that allows tracking of the target mRNA knockdown because the miR-30 sequences induce the Drosha and Dicer processing of the expressed target sequence. The promoter drives the micro RNA adapted short hairpin RNA. If the Drosha/Dicer degradation complex recognizes the target sequence specified by the shRNA, then the transcript of the target sequence and the TurboRFP transcript is degraded. The construct allows fast testing of the efficiency of shRNAs [177].

Table 6. Inducible promoters.

\begin{tabular}{cccc}
\hline $\begin{array}{c}\text { Inducible } \\
\text { Promoters }\end{array}$ & Size (bp) & Origin, Cell Expression, Strength & References \\
\hline MT-1 & 13,200 & $\begin{array}{c}\text { Zinc, cadmium or copper-inducible sheep } \\
\text { metallothionine-Ia promoter }\end{array}$ & [174] \\
\hline MMTV LTR & 792 & $\begin{array}{c}\text { dexamethasone (Dex)-inducible mouse mammary } \\
\text { tumor virus. Active when glucocorticoids or } \\
\text { progestins present }\end{array}$ & {$[175,176]$} \\
\hline Ptet & 270 & $\begin{array}{c}\text { tetracycline On or Off system promoters (Ptet). 6x } \\
\text { mutated TRE ( 200 bp) core CMV ( 40 bps) }\end{array}$ & {$[177]$} \\
\hline T7lac & 42 & $\begin{array}{c}\text { T7 bacteriophage promoter (17 bp) requires T7 RNA } \\
\text { polymerase and lac operator (25 bp). Induces } \\
\text { expression by IPTG }\end{array}$ & {$[180]$} \\
\hline Riboswitches & $\sim 100$ & $\begin{array}{c}\text { ligand-sensing aptamer, a communication module } \\
\text { (linker), and an effector domain (ribozyme) }\end{array}$ & {$[173,178,179]$} \\
\hline
\end{tabular}

Riboswitches have gained considerable attention for rAAV ocular therapies because of their small size (100 bp cis-acting RNA sequence), adaptability to ligands, and the development of synthetic riboswitches $[173,178,179]$. The riboswitch encodes for a ligand-sensing aptamer, a communication module (linker), and an effector domain (ribozyme) that depending on the presence of the ligand, cleaves the mRNA of the gene expression cassette. A proof-of-concept-study for anti- vascular endothelial growth factor (VEGF) expression by the activating ligand tetracycline in a wet AMD mouse model demonstrated the feasibility of the riboswitch in ocular gene therapy [179].

\section{Optimizing Genes for rAAV Vector Therapies (Minigenes, Dual/Triple rAAV-Vector, ITRs)}

\subsection{Intron Removal, Exon Removal, Surrogates, and Pathway-Modifying Therapies}

rAAV transgene cassettes only allow expression of small genes because of the limited packaging size of around 4.5-4.6 kb (excluding the two ITRs). It has been challenging to fit large genes into rAAV vectors. Introns and sometimes exons are truncated to allow proper packaging. Thus, many large cDNAs in rAAV gene cassettes do not contain any or contain only a few native introns (see Table 1, and Table S1). Introns can serve many functions, for example, to increase mRNA stability, modulate RNA synthesis rate, introduce alternative splicing, and decrease DNA damage of highly expressed genes. Moreover, an intron can dictate the mRNA export mechanism from the nucleus to the endoplasmic reticulum [181,182]. Removal of introns in rAAV gene cassettes might further alter the intrinsic gene regulation apart from artificial promoters and rAAV expression system. For example, the CRB1 protein (UniProtKB P82279-1) consists of 1406 amino acids and is encoded by 210,251 bp (GRCh37 $197,237,334-197,447,585$. ENSG00000134376). The exon-coding sequence alone is $4221 \mathrm{bp}$, including the $3^{\prime}$ stop codon, whose size is close to the maximum packaging capacity of the rAAV. Nevertheless, we achieved an efficient expression of CRB1 in retinal cell types by making use of short promoters $(<300 \mathrm{bp})$ and a $50 \mathrm{bp}$ synthetic polyadenylation sequence [60].

Shortened versions of proteins (exon truncations aka minigenes) are generally not advised because many shortened proteins lose their functionality. For example, many shortened versions of the 
Duchenne muscular dystrophy gene (DMD; $2.3 \mathrm{Mb}$; 79-exons; 3685 amino acids; $11,055 \mathrm{bp}$ ) do not rescue the Duchenne muscular dystrophy phenotype in muscle cells except for the micro-dystrophin for which was reported a milder clinical phenotype [183,184]. Nevertheless, the micro-dystrophin rescue in patients in clinical trials has been at least suboptimal and needs further optimization [185]. We also tried a native occurring short version of the CRB1 protein encoded by a CRB1 cDNA lacking exons 3 and 4 while maintaining the open reading frame, but whereas the short CRB1 (sCRB1) was expressed, it also caused retinal degeneration upon subretinal injection of the AAV9-CMV-sCRB1 or AAV9-hGRK1-sCRB1 [24]. Moreover, the CEP290 gene (7.5 kb cDNA coding for 2479 amino acids) is too large to fit in a rAAV vector. A smaller version of the CEP290 cDNA (minigene miniCEP290 $580-1180$ coding for the RAB8A-binding domain) temporarily rescued in part the ciliary length and retinal function in the Cep290 ${ }^{\text {rd16 }}$ mouse [186]. The company Ophthotech (now Iveric) explores the miniCEP290580-1180, a mini $A B C A 4$ (no published information available), and miniUSH2A (no published information available) for rAAV vector therapy. The USH2A gene (15.6 kb cDNA coding for 5202 amino acids) cDNA has been shortened to the miniUSH2A-1 ( $6.8 \mathrm{~kb})$ and miniUSH2A-2 $(\sim 4.1 \mathrm{~kb})$ and delivered by Tol2 transposase mRNA into homozygous one-cell staged $u s h 2^{\text {armc1 }}$ zebrafish embryos restoring visual motor responses and retinal function [187].

Instead of employing a shortened protein, one can also apply a surrogate protein such as utrophin for dystrophin $[185,188]$. We also developed a surrogate gene therapy for patients with CRB1-related retinal dystrophy by employing the Crumbs homolog 2 gene $(C R B 2 ; 3.8 \mathrm{~kb})$. However, such a strategy can only be performed if the proteins of interest execute similar functions in cells, which is the case for CRB1 and CRB2 [62,189-202]. The rAAV-CMV-CRB2 rescued the loss of CRB1 function in mouse Müller glial cells [60]. Interestingly, mice lacking CRB1 or mouse retinas lacking CRB2 develop the same phenotype as observed in human iPSC-derived retinal organoids lacking CRB1 [62]. Surrogate proteins might be less immunogenic than the native protein — such as utrophin over dystrophin-because the surrogate protein is already expressed in the body. Surrogate proteins could have great potential for many $\mathrm{rAAV}$ gene therapies.

The identification of key players in signaling pathways (e.g., VEGF, TGF- $\beta$, Wnt) is an exciting but complex research area. Here, exemplified on glaucoma therapies, the expression of a key player is altered (e.g., by antibody or viral vector administration) to induce a lasting change on intraocular pressure (IOP). The search for key players is generally on: (a) mutated genes that are more frequently found in patients with glaucoma (single nucleotide polymorphisms [SNP] databases; e.g., $C A V-1$ ), (b) genes affected by glaucoma (e.g., data from [single-cell] RNAseq healthy-disease condition databases; e.g., ANGPTL7, MMP1, and PLAT), or (c) gene products that are actively involved in regulating the intraocular pressure (e.g., data from knock-out/in gene library screens and literature searches; e.g., RhoA-Rho kinases and prostaglandin EP4 agonists) [203]. Similar approaches are explored for the identification of pathway genes for RP and LCA.

The expression of pathway-modifying factors can be done by the injection of neuronal progenitor cells that release growth factors (jCyte, Inc, product jCell; ReNeuron Limited, product hRPCRP) or viral vectors expressing the specific key player (see Figure 1, Table 1 rAAV products for AMD/glaucoma). Cell survival factors, such as pigment-endothelial-growth factor (PEDF), are discussed in the Section 3.3. For example, the suppression of the vascular endothelial growth factor receptor (VEGFR) activation and the complement cascade activation in the RPE and choroid by repeated intravitreal antibody injections is successfully used in clinical studies [204]. This led to the development of rAAV gene cassettes that express upon infection a soluble protein fragment that partially binds to the VEGF receptor or complement system proteins inhibiting the disease pathway cascade. The vectors have efficiently prevented a full-blown AMD phenotype in AMD models and are currently tested in clinical trials: (1) the small soluble fms-like tyrosine kinase-1 (sFlt-1. Non-membrane associated splice variant of VEGFR1 encoded by the FLT1 gene; Adverum Biotechnologies; Sanofi Genzyme) $[41,205,206]$, (2) endostatin (cleavage product of collagen XVIII)/angiostatin (cleavage product of fibrinogen; Oxford Biomedica) [207], (3) the complement factor I (CFI, a C3b/C4b inactivator in the complement 
cascade; Gyroscope Therapeutics) [208], (4) anti-VEGFfab Heavy chain and anti-VEGFfab Light chain (Regenxbio) [209], and (5) the soluble CD59 antigen (binding to C5b preventing C9 incorporation in the complement cascade; Hemera Biosciences) [210].

Finally, the expression of light-activated opsin-like proteins are explored to restore (partial) vision in RP patients (see Table 1 rAAV products RST-001, GS030, and BSO1). Three different fluorescent proteins (ChR2 aka Channelrhodopsin-2 [930 bp], ChR88m19-tdTomato aka ChrimsonR [2496 bp], and Chr90 aka Chronos [1710 bp]) are explored in clinical trials [211,212]. Chronos-GFP (green-shifted) and ChrimsonR-tdTomato (red-shifted) are second generation fluorescent proteins that have faster kinetics and are more light sensitive compared to ChR2. Further tests are needed to find out which approach restores optimal vision in patients with ocular diseases: (1) a wild-type or surrogate gene (e.g., $C R B 1$ or $C R B 2$ to a CRB1-RP patient), (2) a shortened gene supplementation (e.g., miniCEP290 ${ }^{580-1180}$ ), (3) neuroprotective factors (e.g., CNTF), (4) the delivery of antiangiogenic factors (e.g., sFLT1), or (5) disease pathway-modulation (e.g., ANGPTL7 in glaucoma), or (6) the introduction of a light-activated protein. We will mainly focus on the supplementation of a wild-type copy of a gene for the rest of the review.

\subsection{Lentiviral and Dual/Triple rAAV Vectors}

Retroviral 3rd generation lentivirus-based systems have a larger packaging size of $\sim 8.5 \mathrm{~kb}$ compared to $4.5-4.6 \mathrm{~kb}$ in rAAV [213]. They can infect both dividing and non-dividing cells and integrate into the genome. Equine infectious anemia virus (EIAV) 3rd generation lentivirus-based gene therapies for the MYO7A gene ( 6645 bp; 2215 amino acid) and the $A B C A 4$ gene (6819 bp; 2273 amino acids) delivered to photoreceptors have been in clinical trials for Usher syndrome type I and Stargardt disease (NCT01367444; NCT01505062) since 2011/2012, respectively. Lentiviral vectors efficiently infect RPE but it is less clear how efficient these vectors are on photoreceptors. The results of the clinical gene therapy studies might tell us whether or not the EIAV lentiviral approaches onto photoreceptors have been efficacious.

Dual and triple rAAV vectors are another strategy to circumvent the small capacity of rAAVs. Nicked ITRs ( $\triangle$ ITRs) have been used that allow for annealing of two or three different rAAV gene cassettes. An update on dual and triple rAAV vectors can be found in a recent paper by Trapani [214] who successfully applied a dual ABCA4 AAV vector system in Abca4 knockout mice $[215,216]$. The first generation of dual $\mathrm{rAAV}$ vector cassettes resulted in a high ratio of truncated gene expression. Adjustments, such as 200-300 bp of specific compatible overhangs, have resulted in normal concatemerization of independent gene cassettes such as the hybrid dual rAAV approach [214].

\section{3. rAAV-Vectors Expressing CRISPR/Cas}

Staphylococcus aureus CRISPR associated protein 9 (SaCas9) is an RNA-guided endonuclease enzyme associated with the CRISPR (type II prokaryotic Clustered Regularly Interspaced Short Palindromic Repeats) complex. Cas9 unwinds, checks, binds, and finally cuts in the DNA (causing a double-stranded DNA break [DBS]) complementary to the annealed 20-nucleotide genome-specific part of the single guide RNA (gRNA). The genome-specific part of the gRNA anneals proximal to the 3-bp protospacer adjacent motif (PAM). The guide RNA can be adjusted to target the whole genome as long as a PAM sequence is found close by (for S. aureus: NGG). Many Cas protein homologs and orthologs have been described with the most significant ones for rAAV gene-editing cassettes being Cas9, Cas12a (Cpf1), Cpfl1, SpCas9, SaCas9 [217]. The large Cas9 (SpCas9, 4100 bp) or type-V Cas system (AsCpf1, $3921 \mathrm{bp} ;$ L LCpf1, $3684 \mathrm{bp}$ ) together with the gRNA cassette generally do not fit smoothly in a single rAAV gene cassette. The new generation of SaCas9, CjCas9, and NmCas9 (2.9-3.3 kb) allows the packaging of both Cas9 and gRNA in a single AAV vector. CRISPR/Cas gene editing can inactivate the dominant-negative effect or can regulate positively or negatively the transcription of genes. However, if left active in cells, functional rAAV-CRISPR/Cas9 systems do increase the number of off-target integration events into the genome [218]. 
The large $S p C a s 9(4.1 \mathrm{~kb})$ would require a dual rAAV system to incorporate all elements, including the gRNA cassette. A dual rAAVs system (rAAV.RKp.SpCas9; rAAV.U7.gRNA-Nrl) rescued vision in three mouse lines of rod retinal degeneration $\left(\mathrm{Cr} x-\mathrm{Nrl}^{--}\right.$; $\mathrm{rd} 10$ or $\left.\mathrm{Pde}^{\mathrm{d}} 6 \mathrm{~b}^{--} ; \mathrm{Rho} \mathrm{o}^{--}\right)$by knocking out $\mathrm{Nrl}$ in one or both alleles [219].The Nrl-knockout pushed rod photoreceptors to a more cone-like state helping in the survival of the remaining photoreceptors. Similar results have been reported in a second independent study [220]. The mutant rhodopsin gene encoding a dominant-negative form of rhodopsin $\left(R h o^{P 23 H / P 23 H}\right)$ was also silenced by gene editing in a mouse model of retinal degeneration $\left(R h o^{P 23 H / P 23 H}\right)$ by a dual rAAV-vector administration (rAAV2/8(Y733F)-sCMV-SpCas9.spA and rAAV2/8(Y733F)-U6.gRNA1gRNA2(mRho).mRho.hRHO.SV40-polyA) rescuing retinal degeneration [61].

A shorter Cas protein, CjCas9 (2950 bp), allows expression from a single rAAV vector. Intravitreal injection of a single rAAV2/9-vector at $\mathrm{P} 0$ in mice efficiently downregulated angiogenesis genes in mice (rAAV-gRNA against Vegfa:Hif1a.CjCas9-T2A-GFP). The downregulation was linked to a decrease in spot size on morphology of the laser-induced choroidal neovascularization (wet AMD model) but not on retinal function measured by electroretinogram (ERG) [221]. Their follow-up paper showed that 14-months post-injection, the CjCas 9 is still active but does not affect the retinal function indicating that the therapy might be safe [222].

Cas proteins can also be altered and fused to other proteins. For example, the $3.2 \mathrm{~kb}$ cDNA encoding a nonfunctional nuclease-activity-dead S. aureus ortholog Cas9 (dCas9) can be fused with a cDNA encoding a transactivation domain such as VP64 fused to the two transcription factors p65 and Rta (dCas9-VPR). The cDNAs encoding VP64, p65, and Rta are 150 bp, 357 bp, and 570 bp in length, respectively. Because of the relatively large size of $4277 \mathrm{bp}$ of $d C a s 9-V P R$ cDNA, the authors used a dual rAAV system to express the $d$ Cas $9-V P R$ and gRNA expression cassettes $[223,224]$. Recently, a single rAAV expression vector has been developed driving the gRNA by a U6 promoter ( $360 \mathrm{bp}$ ) and a shortened but $3 \times$ less active VPR (500 bp) and $d S a C a s 9$ (3200 bp) from an SCP1 promoter ( $80 \mathrm{bp}$ ) attached to $2 \times$-sNRP-1 polyA signal (34 bp). A modified rAAV-vector version with a full-length CMV promoter and the bGHpolyA efficiently upregulated a gene (Actc1, Neurog2, or Hbb) upon infection of N2A neuron derived cells by $50-150 \times$ in vitro [167]. A single rAAV vector expressing dCas9 fusion protein, as well as a sgRNA, shows excellent potential for positive or negative regulation of transcription in many genetic pathways involved in retinal diseases. Several other exciting Cas 9 gene cassettes in rAAVs will most definitely be developed. A recent review reported a rAAV-CRISPR vector that can self-inactivate its Cas9 protein by encoding an anti-Cas9 gRNA on the same construct that harbors the Cas9 itself [148]. Nevertheless, single guide RNAs ( $s g R N A$ ) comprise short hairpin sequences that potentially cause truncation of the rAAV production similar to short-hairpin RNAs (shRNA). Placing the gRNAs close to the second ITR might increase the production yield and increase proper vector expression upon infection of the target cells [147].

\subsection{Production and $r A A V$ Vector Integration}

\subsubsection{Production: The Backbones and Bacterial Resistance Genes}

Impurities in rAAV products hinder the release of pharmaceutical products but might also negatively impact the potency of the expression vector. During the rAAV production, the gene therapy vector is packaged in the rAAV capsids. However, under suboptimal conditions, the capsids do also package other sequences such as vector plasmid backbones $(\sim 3 \%)$, helper plasmids $(\sim 0.05 \%)$, and even human genome sequences $(\sim 0.15 \%)$ [225]. Increasing the size of the vector plasmid backbone to above $5 \mathrm{~kb}$ considerably reduced inappropriate packaging and also reduced the number of empty capsids. However, larger plasmids give lower DNA plasmid yields in bacterial culture and are somewhat harder to transfect efficiently into cell lines. Jean Bennett's group enhanced safety and maximized the therapeutic effect by adding a stuffer sequence for rAAV product hRPE65v2 $[39,226]$. The global health agencies (FDA, EMA, WHO) also discourage the use of $\beta$-lactams (i.e., ampicillin, penicillin) 
and streptomycin resistance genes in plasmids for gene therapy [227]. Kanamycin and neomycin are both members of the aminoglycoside antibiotic class. These antibiotics are tolerated, but switching to antibiotic-free systems or minimizing the use of antibiotics is preferred. Some researchers use, therefore, minicircle DNA vectors devoid of prokaryotic and antibiotic DNA sequences for their AAV production [228]. No differences were found for minicircle single-stranded rAAV2.eGFP production. For the self-complementary rAAV2.GFP vector, the plasmid backbone was packaged 30 times less into capsids. Moreover, the use of minicircle plasmids during rAAV production allowed for high transduction titers of rAAV vectors on HeLa cells [229].

Pro-viral plasmids can also include short-hairpin RNAs to downregulate host cell proteins that hinder rAAV capsid assembly during production. Downregulating the Y-box binding protein 1 (YB1) in HEK293T cells did increase the physical titer by $47 \times$ for rAAV2, yet it failed to improve the yield for rAAV5 [163].

\subsubsection{Production: ITR Stabilization}

An inverted terminal repeat (ITR) of rAAV consists of an A-A', RBE-RBE', B-B', C-C', D, and terminal resolution site (trs) sequence (Figure $4 \mathrm{~A}$ ). The AAV Rep78 and Rep68 proteins expressed by the pHelper plasmid induce a nick on the terminal resolution site on the ITR [230]. The RBE-RBE' initiates the binding of Rep78 and Rep68 proteins, and the B-B' further stabilizes the proteins so the Rep78 and Rep68 can efficiently induce DNA replication during the rAAV production cycle [231]. The D sequence is the packaging signal, is important for the AAV replication, and can bind the double-stranded D sequence binding protein (ds-D-BP) [232-234]. When high copy numbers of a D sequence expression vector are present in HEK293 cells, then the interferon- $\lambda$-mediated activation of the major histocompatibility complex class II (MHC-II) is dampened, potentially by the binding of the ds-D-BP protein with the D-sequence instead of the X-box (RFX) regulator [235]. rAAV can be produced with only one ITR if the other ITR shows specific deletions, and ITR deletions can be recovered during production $[233,236]$. Moreover, replacing the $5^{\prime}$ ITR with a U-shaped hairpin allows rAAV production and episomal concatemerization [147]. A systematical study into ITR mutations (deleting B-B and C-C' regions) indicated a reduced yield (4-8× fold) but a 4 -fold increased transgene expression in HEK293 cells 72 hours post-infection [237]. The deletion of the BC region caused an ITR change from a T-shape to a U-shape hairpin (similar to short hairpin RNA). The authors postulated that the $2 \times 34$ bp ITR deletions might allow larger packaging of rAAV gene cassettes.
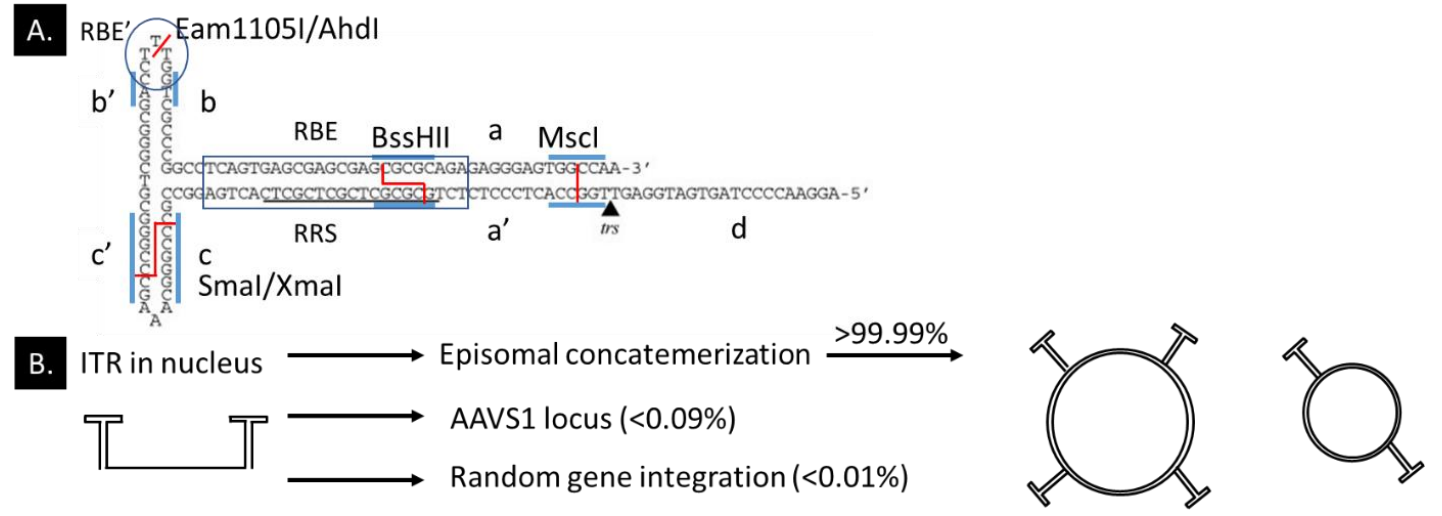

Figure 4. How to assess Inverted Terminal Repeats (ITRs) of rAAV and how they allow concatemerization. (A) Restriction enzyme sites in the AAV serotype 2 ITR in the flop configuration. RBE'/RBE binds Rep68 (RBE, Rep-binding element) and initiates the Rep helicase. The Rep helicase nicks the trs (terminal resolution site). Restriction enzyme recognition site indicated in blue and the actual cut in red. Figure adapted from [238]. (B) ITR structure in the nucleus after second-strand DNA synthesis in dividing cells favoring homologous recombination. Most rAAV-vectors form episomal concatemeric circular double-stranded DNA. 
Recombinant AAV plasmids can disrupt ITRs in many E. coli cells during plasmid production or rAAV production. We also noticed an almost complete loss of one ITR within one production cycle of a pro-viral plasmid in bacterial GeneHog cells (Invitrogen) (TMB and JW, unpublished data). We validated the loss in the pro-viral plasmids by restriction enzyme digestion with XmaI at the C-C', BssHII for the RBE, and Eam1105I for the RBE' region. ITR Sanger sequencing has been intricate on circular DNA. We sequenced the whole ITR by first linearizing the plasmid by Eam1105I digestion at the RBE', and then Sanger sequenced the pro-viral plasmid from both directions. The method allows us to use similar functional ITR ratios between batches (Figure 4A).

\subsection{3. rAAV Vector Integration into the Host Genome and Chromatin Association}

Integration of rAAV into the host cell genome is unwanted because it might be genotoxic and lead to oncogenesis, especially in dividing cells and non-target cells. The rAAV gene cassettes only harbor the palindromic inverted terminal repeats (ITR) of the original wild-type AAV. All other AAV wild-type sequences are lost during the $\mathrm{AAV}$ production. The ITRs are part of the Long Terminal Repeats (LTRs) family. The LTRs are extensively exploited by retrotransposons or the pro-viral DNA of retroviral RNA. ITRs, similar to LTRs, are essential to allow AAV genome integration or episomal concatemerization. The ITR hairpin structures allow self-priming (primase independent synthesis of double-stranded DNA). The ITR-gene cassette stays as a monomeric episomal form in the nucleus at low multiplicity-of-infection (MOI). At high MOIs, the ITRs form head-to-tail end-to-end joining, essentially making circularized DNA $(>12 \mathrm{~kb})$. Further, the $5^{\prime}$ LTR generally has a promoter function, and the $3^{\prime}$ LTR can act as a termination sequence. Each of the ITRs of the AAV serotype 2 (ITR2) is only $145 \mathrm{bp}$ long and lacks the promoter and termination functions (Figure 2B).

Chromatin-modifying proteins have been extensively studied but are viewed as less relevant for rAAV vectors because $\mathrm{AAAV}$ vector DNA, resides mainly in a concatemeric-episomal conformation in the nucleus, therefore potentially less regulated by epigenetics [23,239]. However, chromatin immunoprecipitation did pull down rAAV concatemer vectors after treatment with histone deacetylase inhibitor FR901228 of rAAV infected cells suggesting that rAAV might interact with histone-associated chromatin [240]. Moreover, viral DNA in minichromosomal confirmation has an identical density to chromosomal DNA indicative that chromatin-modifying factors might play a role for rAAV vectors [241]. Besides, the knockdown of chromatin assembly factor 1 increased rAAV transduction in HeLa cells [242]. Further studies need to address what kind of roles the chromatin-modifying factors have on naked DNA rAAV vectors in minichromosomal conformations in the nucleus. It is also interesting to point out that part of the infectious rAAV viral particles may redistribute to neighboring cells and may remain long term in the cytoplasm and nucleus [243].

rAAVs lack viral proteins for efficient genome integration. Integration of foreign DNA (rAAV gene cassettes) into the mammalian genome is related to the amount of double-stranded DNA (dsDNA) breaks and the DNA repair pathway that is active in the cell. Integration events can be increased by increasing dsDNA breaks in vitro by adding intron-encoded endonuclease I-SceI, etoposide, or $\gamma$-irradiation [244]. Dividing cells favor the homologous recombination (HR) DNA repair pathway during the cell cycle S-phase that requires a DNA template to guide repair such as a viral gene cassette. However, quiescent cells, such as retinal and RPE cells, favor the nonhomologous end-joining (NHEJ) pathway ligating the ends directly without the insertion of a template.

The safety profile of the rAAV relies on that upon intravenous injection, more than $85-95 \%$ of rAAV vector genomes remain episomal in the dividing hepatocytes in the mouse liver (Figure 4B; [245]). The study might have overestimated integration events in hepatocytes. Others estimate the AAV integration events closer to $0.1-1 \%$ [246]. Yet, follow-up studies indicated that $53-62 \%$ of rAAV integrations in the liver fused into actively-transcribed genes, and 3-8\% into ribosomal DNA [247]. rAAV genome integration into mouse muscle tissue DNA compared to hepatocyte DNA was hard to detect or not present, indicating that the integration frequency also depends on the cell type [23]. Integration of wild-type adeno-associated virus (wtAAV) compared to rAAV for human cardiomyocytes 
at high MOI (50,000 viral particles per cell) was 5.6× higher with both AAVs integrating into mitochondrial DNA [248]. A recent study looked at integration events in nonhuman primates and patient DNA in clinical trials (liver biopsy) that received the rAAV2/5-cohPBGD and found $10^{-3}$ to $10^{-5}$ integration events per cell or $0.04-9 \%$ integration events [249]. Very little information is available for $\mathrm{rAAV}$ vector genome integration events into retinal tissue. A recent CRISPR/Cas9 study indicated that Cas 9 breaks caused $>1-20 \%$ insertion events of the rAAV cassette (EDIT-101) into the dsDNA break in the CEP290 intron in human retinal explant DNA, not counting integrations in other regions of the genome [250]. The insertion of the rAAV was higher when more indels, deletions, and inversions were detected (over 25 independent samples). The results indicate, as expected, that rAAV integrations events in photoreceptor cells correlate to the rAAV dosage. rAAV integration studies in the retina is an underrepresented research field. Almost no rAAV study specifically investigated rAAV integration events.

The integration of rAAV vectors at ribosomal DNA (rDNA) can be exploited by adding $1 \mathrm{~kb}$ homology arms of the rDNA locus adjacent to the ITRs. The homology arms increased the integration frequency in dividing cells favoring homologous recombination by $10-30 \times$ from a baseline of $0.001-5 \%$ AAV vector integrations per 100 cells (depending on the vector dose). Further, many rAAV gene cassette integrations caused deletions in the genome [251].

The unique T-shape AAV serotype 2 ITR-DNA (ITR2) conformation enables even gene editing. A defective eGFP reporter plasmid in dividing cells was rescued (gene-edited) by adding only the ITR2-eGFPpart(165 bp)-ITR2 with 40 bp eGFP homology arms adjacent to the ITR2 [252]. Nevertheless, the rAAV gene expression from integration events is generally silenced within eight passages. Moreover, wild-type AAV integrates preferentially at $94 \%$ at the AAVS1 locus on chromosome 19 (Chr19) because the ITR sequence is homologous to the AAVS1 locus, but this requires the AAV integrases Rep78 and Rep68 that have been removed in rAAVs. Thus, rAAVs do not integrate at the AAVS1 locus. Interestingly, very little to no rAAV integration has been found in the genome of CRISPR/Cas9 gene-edited quiescent cells suggesting that off-target editing requires cell division. Unmistakably, many successful AAV gene therapies in mice and $>130$ rAAV clinical trials in humans, have indirectly suggested that the genome integration/genotoxic events are of a lesser concern [249].

\subsection{Codon Optimization and Self-Complementary $r A A V s$}

The final rAAV gene cassette could be codon-optimized to improve the optimal expression of the transgene in the target cell and organism. Essentially, codon-optimization is primarily looking at codon frequencies that might rate limit the transcription of the gene in the target cell, such as favoring the codon GUG over GUU for valine in humans. The codon optimization of rAAVs should prevent the inclusion of potential hairpin structures, repeats, extreme GC content, alternative open reading frames (ORF), and cryptic splice sites. Different codon optimizations have been tested for the rAAV gene therapy for Crigler-Najjar syndrome that increased the FIX transgene expression by 4-10-fold [253], and codon-optimization of rAAV2/5.hRPE65.hRPE65 to rAAV2/5.OPTIRPE65 might allow for higher levels of transgene expression and the use of lower rAAV titers to reduce temporal capsid-mediated toxicity [36]. For the rAAV vector AGTC-501 expressing the human RPGR-ORF15 gene, the Codon Adaptation Index (CAI) of human codon-usage frequency was increased from 0.73 to 0.87 , and the Frequency of Optimal Codons (Fop) was increased from 32\% to 57\%. Further, the GC content was increased, and the maximum repeat size decreased. Such adaptations in the AGTC-501 vector resulted in reduced frequency of alternative splicing and increased mRNA stability $[43,110]$. Interestingly, the same stabilized RPGR sequence of the AGTC-501 produced a full-length RPGR-and a truncated form of RPGR-ORF15 in the retina of mice in vivo. However, when applied to HEK293T cells in vitro, then the AGTC-501 vector produced only the full-length RPGR-ORF15 protein. The different products produced from the same RPGR expression cassette indicated species differences in the regulation of gene transcription or RNA splicing or differences between in vitro versus in vivo transgene expression 
systems. Transgene expression cassettes for clinical retina studies should, therefore, be tested in cultured human cells and preferentially in human retinal organoids or human RPE cells.

Recombinant self-complementary AAV (scAAV) vectors are more potent to express high levels of transgenes than recombinant single-stranded AAV (ssAAV) vectors. Once the cell is infected by the scAAV and the scAAV becomes decapsidated, the rate-limiting step to create double-stranded DNA is overcome more efficiently in scAAV than in single-stranded rAAV. A major disadvantage of scAAV is however the reduced packaging capacity of the gene expression cassette from up to $4.9 \mathrm{~kb}$ to a maximum of $2.5 \mathrm{~kb}$, including the two ITRs. ScAAV mediated transgene expression could be enhanced by 5 up to 140 fold in vitro [254], and a further $90 \%$ increase in the yield of dimeric genomes was be achieved by deletion of the terminal resolution site sequence from one ITR (ITR2 $\Delta$ ) [255]. When compared to ssDNA, lowered rAAV doses of scAAV gene therapy vector can be used to reach similar transgene expression levels in the retina in vivo $[101,152,256,257]$. ScAAVs can also have significant effects on the promoter choice. The rescue by subretinal injection of scAAV8-sRLBP1p.RLBP1 rescued the rate of dark adaptation measured by electroretinography (ERG) in Rlbp1 knockout mice [101,152]. The transcription of $h R L B P 1$ by a short RLBP1 promoter increased 50-fold at a low dose $\left(1 \times 10^{8}\right.$ viral genome $)$ and 6.4 fold at a high dose $\left(1 \times 10^{9}\right.$ viral genome $)$ in cynomolgus monkey retina. The scAAV might be especially beneficial when weak promoters are required or if low viral doses are desired to prevent capsid toxicity of specific target cells. Specific details on scAAV can be found in a recent review by McCarty [255].

\section{Transgene and Bioactivity Assays in Ocular Tissue}

Quality control is essential in rAAV production. Quality control includes testing the rAAV production on safety (sterility, viral contaminants, mycoplasma, endotoxins, bacterial and fungistatic activity), appearance, $\mathrm{pH}$, osmolarity, potency (viral genome titer, infectivity, expression), purity, and vector genome identity [258]. Here, we focus on the rAAV potency: infectivity and in vitro and in vivo expression.

\subsection{In Vitro Immortalized Epithelial Cell Lines for Transgene and Bioactivity Assays}

The most straight forward, high-throughput, fast, cheap, robust, but less predictive transgene expression assays are still monoculture systems in vitro. The ideal system would allow a fast characterization of the transduction profile, including rAAV capsid-specific infection, promoter expression profiling (mRNA level), and protein-of-interest expression. Such an assay would allow fast screening of different gene cassettes in research development but also validating the gene therapy products and batches in the clinical-grade production cycle.

rAAV transfection efficiency (potency: infectivity) and transgene expression (potency: in vitro expression) has been tested on rAAV epithelial production cell lines (for example: HEK293T, HER911, HeLa-E1, Per.C6). One can measure the rAAV infection or functional titers measured in transducing units per $\mathrm{mL}(\mathrm{TU} / \mathrm{mL}$ ) by two common assays: (1) median tissue culture infective dose (TCID50) based on rAAV-vector (MOI 20,000 viral genome/cell) infecting HeLaRC32 (HeLa AAV rep-cap expressing cell line) and concomitant adenovirus type 5 (Ad5; 500 IUs/cell) infection (Outcome: vector genome quantification). (2) Infectious center assay (ICA) based on HeLaRC32 and Ad5 (500 IUs/cell) infection (Outcome measure: hybridization of a probe to the rAAV gene cassette). The HeLaRC32 cells allow rAAV replication if the rAAV gene cassette can enter the nucleus [259].

Spark Therapeutics also developed an in vitro potency assay for rAAV-RPE65 vectors. Here, modified HEK293 cells constitutively expressing lecithin-retinol acyltransferase (LRAT) are transduced by the rAAV-RPE65 at different MOIs. Then, 72 hours later, the cells are lysed by adding lysis buffer, and the lysate is incubated with all-trans-retinol and CRALBP for 2 hours in the dark to assess the enzymatic activity of RPE65 (an isomerohydrolase) to convert all-trans-retinol to 11-cis-retinol [260]. The rAAV-REP1 for the treatment of choroideremia is assessed on in vitro prenylation of RAB6A in HEK293 cells [261]. The directly injectable dose can also be assayed. The potency of the residual 
diluted vector (rAAV2-REP1) from the syringe used to inject patients was applied to the REP1-deficient cell line HT1080 for REP1 expression [155]. An endothelial-like Human Trabecular Meshwork (HTM) immortalized cell line is currently explored for glaucoma $\mathrm{AAV}$ gene therapy. Still, the surrogate cell line might also be interesting for studying the off-target effects of rAAV vectors injected intravitreally [262, 263]. However, it is not always possible to develop informative assays on epithelial cells, especially for large screens for novel retinal-specific capsids or retinal specific promoters. For example, rAAV5 vectors infect very poorly HEK293 cells, HeLa cells, and BJ fibroblasts [264] but infect RPE cells and human retinal organoids efficiently [62,265]. Consequently, if a rAAV5-CAG vector does not express a transgene product in a HEK293 assay, then the vector might still express the transgene in human RPE or human retinal organoids.

\subsection{In Vitro Immortalized Ocular Cell Lines for Transgene and Bioactivity Assays}

Researchers can also use various human retinal cell lines to achieve improved infection and expression of retinal specific capsids or promoters. Promising ocular cell lines are the $661 \mathrm{~W}$ mouse photoreceptor cell line/retinal ganglion precursor-like cell line (a surrogate for cone photoreceptors), the Adult Retinal Pigment Epithelial cell line-19 (ARPE-19; a surrogate for RPE cells), hTERT RPE-1 (ATCC ${ }^{\circledR}$ CRL-4000 ${ }^{\mathrm{TM}}$ ), human astrocytes and the MIO-M1 (surrogates for Müller glial cells).

$661 \mathrm{~W}$ mouse cell line do not express GFAP but do express neuronal genes such as Opn1SW, Opn1mw, Rbpms, Brn3b, Brn3c, Thy1, $\gamma$-synuclein, nestin, NeuN, Map2C, Map2D, and $\beta$-III tubulin. The 661W cells are light-sensitive but do not have visible outer segments [266,267]. 661W and ARPE-19 cells allow for screening of RPE-specific (mCARpro, MOPS500, VMD2) and ubiquitous (smCBA) promoters for most rAAV serotypes [268]. The $661 \mathrm{~W}$ cell line has been further modified to achieve improved transfection by overexpression of the universal adeno-associated virus receptor (AAVR) or more stably express key photoreceptor genes such as GRK1 and $C A R$ by rAAV-VPR- $d C a s 9$ vector infection [269]. Two major drawbacks to immortalized ocular cell lines are that most tend to be very heterogeneous, some of the cell lines express multiple cell-type-specific markers such as for retinal ganglion cells (Brn3) as well as for cones (Opn1mw) in addition to neuronal cell markers (Nestin, NeuN). Moreover, none of the cell lines have mature photoreceptor outer segments. Another RPE cell line (hTERT RPE1; ATCC ${ }^{\circledR}$ CRL- $4000^{\mathrm{TM}}$ ) was used for liposome co-flotation assays expressing a biological active truncated CEP290 (1-580 amino acid) protein (rAAV-CEP290 ${ }^{1-580 a a}$ ) in the primary cilium [270]. A CEP290 knockout hTERT RPE1 line was constructed, showing the cilia-related CEP290-phenotype [271].

Human primary astrocytes have been successfully employed to select for novel rAAV capsid variants that are specific for (Müller) glial cells. An example are the rAAV6 variants ShH10 and ShH10-Y445F that efficiently infect rat, mouse, and human Müller glial cells [60,62,272]. Human astrocytes also express common Müller glial cell markers such as SOX9, GFAP, GLAST, GS, Kir4.1, and S100ß [273,274]. A human Müller glial-like cell line (MIO-M1) expresses the proteins GLUL, VIM, low GFAP (but found on mRNA level), RLBP1, GLAST, EGFR, SLCA1, AQP4, Kir4.1, THY1, NEFH, MAP2, NEUROD1, NEUN, Nestin, SOX2, Chx10, PAX6, NOTCH1, $\beta I I I$ tubulin. However, the Müller glial-like cell line also contains mRNA for the following opsins or visual cycle-related genes: OPN1SW, OPN2, OPN3, OPN4, OPN5, RRH, GNAZ, GNAT1, and GNAT2 $[275,276]$. The MIO-M1 cell line has been successfully used to screen for rAAV infectivity, rAAV, and lentivirus cell-specific promoter expression [277]. The hypoxia-Müller glial specific promoter (scAAV2.HRSE.6xHRE.GfaABC1D.luciferase) is active in MIO-M1 cells under hypoxic conditions. The hypoxia-induced Müller glial specific promoter showed no luciferase expression in HEK293, C6, HT22, and ARPE19 cells [97].

All described cell lines hold great promise for further rAAV studies. One needs to be cautious of the results because (1) changes in culture condition can strongly affect the "cell-specific" gene expression, (2) cell contamination has been found in several lines such as the rat ganglion cell line 5 (RGC-5) being a subclone of the $661 \mathrm{~W}$ cell line, (3) multiple cell-type-specific gene markers expressed 
for example in $661 \mathrm{~W}$, and (4) the overall lower biologically relevance compared to 2D and 3D cell or in vivo studies.

5.3. In Vitro Differentiation of Human Induced Pluripotent Stem Cells (hiPSCs) to Retinal Pigment Epithelium (RPE) Cells

Human patient induced pluripotent stem cells (hiPSCs) can be differentiated to photoreceptors [278]. 2D differentiation of hiPSCs to photoreceptors peaks at 45 days of differentiation, but it declines fast, making rAAV studies difficult because of the short time window and the inherent instability of inner/outer segments.

Human patient induced pluripotent stem cells (hiPSCs) can also be differentiated to monolayers of RPE. rAAV-REP1 vector transduction of patient hiPSC-derived CHM-RPE rescued the biochemical phenotype [279]. The patient hiPSC-derived RPE can be efficiently used for testing the AAV-CHM vector for rescuing prenylation, phagocytosis, and protein trafficking [280]. Moreover, a proof-of-concept for dominant retinitis pigmentosa due to haploinsufficiency rescued phagocytosis and cilia formation by AAV2/Anc80-PRPF31 in hiPSC-derived PRPF31 ${ }^{+-}$RPE cells [281]. Spark Therapeutics filed a patent application for a potency assay of rAAV-CHM on hiPSC-derived RPE cells lacking CHM expression [282].

\subsection{In Vitro Differentiation of Human Induced Pluripotent Stem Cells (hiPSCs) to Retinal Organoids for Transgene and Bioactivity Assays}

We and other researchers use human retinal organoids to study rAAV transduction and potency [62, $265,283,284]$. In summary, photoreceptors are transduced by rAAVs such as rAAV2, rAAV2-7m8, rAAV5, rShH10, rShH10-Y445F, rAAV8, rAAV8T(Y733F), and rAAV9 albeit at different transduction efficacies. The rAAV2-7m8, rAAV5, rShH10, and rShH10Y-445F capsids infect photoreceptors efficiently. Interestingly though, (early) radial retinal progenitor cells in retinal organoids or common cell lines can efficiently be infected by rAAV6, the rAAV6 variants (ShH10 and ShH10Y-445F), and the AAV2-7m8 [21,62,265,284]. For example, rAAV6 and rAAV-derived vectors (ShH10; ShH10-Y445F) infected hiPSCs and hiPSC-derived RPE cells properly and thoroughly $[21,62,265]$. rAAV2-7m8 and rAAV5 also efficiently infected RPE cells [265,284].

Many challenges still lie ahead of us. We need to learn to properly control rAAV infection of different rAAV capsid compositions. The presence of rAAV receptor-mediated endocytosis is influenced by the docking on of capsid proteins to the cellular receptors on the cell surface. Medium compositions alter the extracellular matrix proteins and has influence on rAAV endocytosis. For example, fibroblast growth factor receptors (FGFRs) are important for the stabilization of the heparan sulfate proteoglycans (HSPGs) on the extracellular matrix of the cell [285]. FGF-2 binds with low affinity to the heparin sulfate chains of HSPGs and the FGFRs [286]. This growth factor can be found in many medium compositions as a supplement or in fetal bovine serum (FBS; $8-45 \mathrm{pg} / \mathrm{mL}$ ) [287]. Many AAV capsids require the HSPGs, the universal AAV receptor (AAVR), and the FGFRs for efficient cell entry. For example, rAAV2 requires the FGFR1 receptor that can be blocked by FGF-2 supplementation [288]. Other rAAV serotypes, such as AAV4, are less dependent on the HSPGs and FGFRs for rAAV capsid cell entry [285]. Thus, the FGF-2 concentration in the medium needs to be defined for rAAV potency assays. Not all co-receptors for $\mathrm{rAAV}$ entries have been discovered yet, adding to the uncertainty of rAAV potency assay data.

Other uncertainties related to the biological relevance and the transgene and bioactivity assays with retinal organoids are: the loss of ganglion cells in long-term culture, improper lamination of the ganglion cell layer (including astrocytes), no innervation of the optic nerve (required for proper foveal development), no vascularization of retinal organoids (therefore, no pericytes), no sclera and Bruch's-membrane (blood-brain barrier), no immune cells (macrophages, microglia, dendritic cells), and no integration with other organs (brain, heart, liver, kidney). Another uncertainty is that the quality of the starting material (hiPSCs) and the culturing protocol can significantly affect the success in 
differentiation to retinal organoids inadvertently affecting rAAV tropism $[289,290]$. More sophisticated models are currently in development. For example, human iPSC-derived retinal organoids and RPE-sheets can be cultured in a microfluidic chip system that enhances photoreceptor maturation and stabilization in vitro [291].

\subsection{Human Ex Vivo Retinal Culture for Transgene and Bioactivity Assays}

We and others have also demonstrated that rAAVs can be tested on ex vivo cadaveric human retinas [50,62,250,292-296]. Ex vivo studies have especially become more attractive since the advent of more efficient medium compositions with better inner-outer photoreceptor segment (IS/OS) quality and ganglion cell survival that allow for longer rAAV-transgene expression. rAAV1, rAAV2[MAX], rAAV2(quad Y-F), rAAV2-7m8, rAAV4, rAAV5, rAAV6 and to a lesser degree rAAV2 and rAAV9 can efficiently infect photoreceptors on ex vivo human cadaveric retinas. We have shown that rAAV5 and the rAAV6 variants ShH10 and ShH10-Y445F can efficiently infect both human photoreceptors and Müller glial cells ex vivo [60,62]. rAAV2(quad Y-F) and rAAV2-7m8 also infected Müller glial cells and some rod photoreceptor cells ex vivo [293,294]. rAAV2/8BP2 infected photoreceptors, Müller glial cells, amacrine cells, ganglion cells, and horizontal cells ex vivo [50] Moreover, the hRLBP1 promoter $(2.6 \mathrm{~kb})$ can restrict expression to Müller glial cells and RPE [60]. Recently, rAAV5.GRK1.SaCas9 vector particles were added to retinal explants that were subsequently cultured for 28 days. The human photoreceptor-specific rhodopsin kinase (GRK1) promoter directed Cas9 expression specifically in human photoreceptors [250]. We have also shown that the GRK1 promoter can limit expression to photoreceptor cells in ex vivo cadaveric human retinas [297].

We have previously shown that mouse retinal explants at P0 can be cultured longer than adult retinal explants [189]. Likewise, human fetal retinae can be cultured for three weeks, with preservation of the general morphology preserved and only the loss of ganglion cells [298]. More astonishingly, fetal retinal tissue that maintained some photoreceptor morphology has been cultured for 293 days in vitro [298]. However, the access to and quality of the donor human fetal material limits the application for many researchers $[62,299,300]$. We observed that efficient transduction of photoreceptors by rAAVs required the presence of well-developed inner/outer segments of photoreceptors. Interestingly, rAAVs infected Müller glial cells more efficiently in explants that showed retinal degeneration [62,294].

\subsection{In Vivo Studies for Transgene and Bioactivity Assays}

\subsubsection{Developmental Stage and rAAV Infection}

Many adult mouse rAAV potency studies have been performed and are reviewed elsewhere [2,7]. It is interesting to note that $\mathrm{rAAV}$ infection can differ depending on the developmental stage of the ocular tissue. Mouse fetal retina (embryonic day 13; subretinal injection) can be transduced well by rAAV 5 but not by rAAV1 and rAAV2. However, rAAV1, rAAV2, and rAAV5 transduce photoreceptors well at P30 [300]. Mouse photoreceptor cells at postnatal day 0 can be efficiently targeted by subretinal injection of rAAV1, rAAV5, rAAV9, and rAAV11 [122]. However, AAV1 transduces mainly RPE cells at the adult stage [2,7]. Moreover, rAAV8-CMV-GFP transduces photoreceptors and Müller glial cells at postnatal day six but only transduces photoreceptors at postnatal day 0 [301]. Here, the rAAV vector containing the CAG promoter compared to the CMV promoter showed expression in more cells (photoreceptors, horizontal cells, amacrine cells, and retinal ganglion cells vs. only photoreceptors) at postnatal day 0 . The difference in the infection efficiency at early development compared to more mature retinas has been linked to rAAV receptors and co-receptors important for rAAV cell entry [284]. The main universal AAV receptor (AAVR) was present already in 44-day-old human retinal organoids. However, the poor transfection efficiency of rAAV9 of retinal organoids $[62,265]$ was linked to the low abundance of N-linked-galactose at early retinal developmental stages [284]. It points to the importance of describing the receptor composition and medium composition accurately at the time of infection to make meaningful comparisons between the infectivity of different rAAV capsids. 


\subsection{2. rAAVs Overcoming Membranes in the Retina and the Retinal Disease State}

Delivery of rAAV gene supplementation to photoreceptors or RPE cells is generally done by subretinal injection because many rAAVs cannot penetrate through the inner limiting membrane (ILM) when injected intravitreally. The ILM is close to the ganglion cells and the Müller glial endfeet with a thickness varying between $100 \mathrm{~nm}$ up to $2000 \mathrm{~nm}$ in nonhuman primates [302]. The rAAV subretinal injection creates a fluid bleb between the retina and the RPE layer causing temporal retinal detachment and infection of cells at foci. Intravitreal injections target a larger retinal area. Intravitreal injections of empty rAAV capsids can induce a temporary immune inflammation of the aqueous and the vitreous [303]. Enzymatic digestion (proteasome inhibitors) of the ILM or ILM/outer limiting membrane (OLM) or disruptions of the ILM/OLM by the disease can alter rAAV infection and allow rAAV infection deeper into the retina [99,294,304,305]. Applying a low trans-ocular electric current also allowed efficient transduction of RPE and photoreceptors by rAAV8 upon intravitreal injection in adult mice [306]. Finally, the application of tyrosine kinase inhibitors might improve the passage of rAAV through the ILM or OLM [307]. The novel methods might make the intravitreal injection more common for photoreceptor and Müller glial cell infection. Intravitreal injection of some rAAVs might result in the transduction of a larger pool of off-target cells, such as the ciliary body and iris epithelium [60].

Disease-induced changes to the retinal morphology do impact the rAAV infectivity. In many retinal diseases, for example in $\mathrm{Crb1}$ retinitis pigmentosa mouse models, we first find that Müller glial cells express stress markers (gliosis), the outer limiting membrane (OLM), which contains adherens junctions between photoreceptors and Müller glial cells disrupts at foci, the inner/outer segments of photoreceptors shrink, some of the photoreceptors die, macrophages and microglial cells are activated and assemble in the photoreceptor segment layers, the outer and inner nuclear layers mix and thin out, and neovascularization takes place [62,189-202]. Likewise, transgenic rats overexpressing rhodopsin variants causing autosomal dominant retinitis pigmentosa show an early (P20), intermediate (P30), and advanced stages of retinal degeneration (P60). rAAV1 or rAAV5 intravitreally injected in rats showed no accumulation of AAV particles at the ILM [304]. However, under the disease condition or enzymatic digestion of the ILM, all $\operatorname{rAAV}(1,2,5,8$, and 9) traversed, most likely via Müller glial cells, to RPE cells through the retina $[99,304,308]$. rAAV2-7m8 vectors infected a wide range of cells in the degenerate retina of $\mathrm{rd} 1$ mice $\left(P d e 6 b^{\mathrm{rd} 1 / \mathrm{rd} 1}\right)$ with little differences found in tropism when the vector was injected subretinally or intravitreally [294]. The potency to infect the degenerate photoreceptors by subretinal injection of $A b c a 4^{\mathrm{KO}}$ mice compared to wild-type mice was lower for four different rAAVs (rAAV2, rAAV5, rAAV2rec2, rAAV2rec3) while the potency to infect INL cells was increased in Pde $6 b^{\text {rd1/rd1 }}$ mice at least for rAAV5, rAAV2/Rec2 [309]. Intravitreal injection of rAAVrh-10 shifted infection from mainly INL cells towards photoreceptor and RPE cells in $R s 1^{\mathrm{KO}}$ and $R h o^{\mathrm{KO}}$ mice (XLRS and RP models, respectively) compared to wild-type mice [310,311]. The studies indicate that disease models allow deeper penetration of rAAVs in disease state compared to healthy retinas with generally lower photoreceptor infection. How well changes in the OLM and ILM impacts rAAV infection needs to be determined separately for each type of retinal disease (Figure 5).

The changes in rAAV vector transduction and expression can be linked to the differentiation stage of cells and cellular stress. Non-dividing terminally differentiated cells allow efficient expression from rAAV gene therapy vectors because the cells downregulate proteins of the DNA damage response [312]. In AMD and retinitis pigmentosa, retinal cells might show an increase in DNA damage response, including more double-stranded DNA breaks and impaired (decreased) autophagy leading to increased cell size, granularity, and protein accumulation [313-315]. How the increase in DNA-damage sensors or the decrease of terminal differentiation is linked to $\mathrm{AAV}$ vector transgene expression needs to be further evaluated. Cell stress-induced expression was observed upon induction of gliosis, by light or application of ciliary neurotrophic factor (CNTF), in Crb1-deficient retina injected intravitreally with rAAV.GFAP.eGFP [99]. 

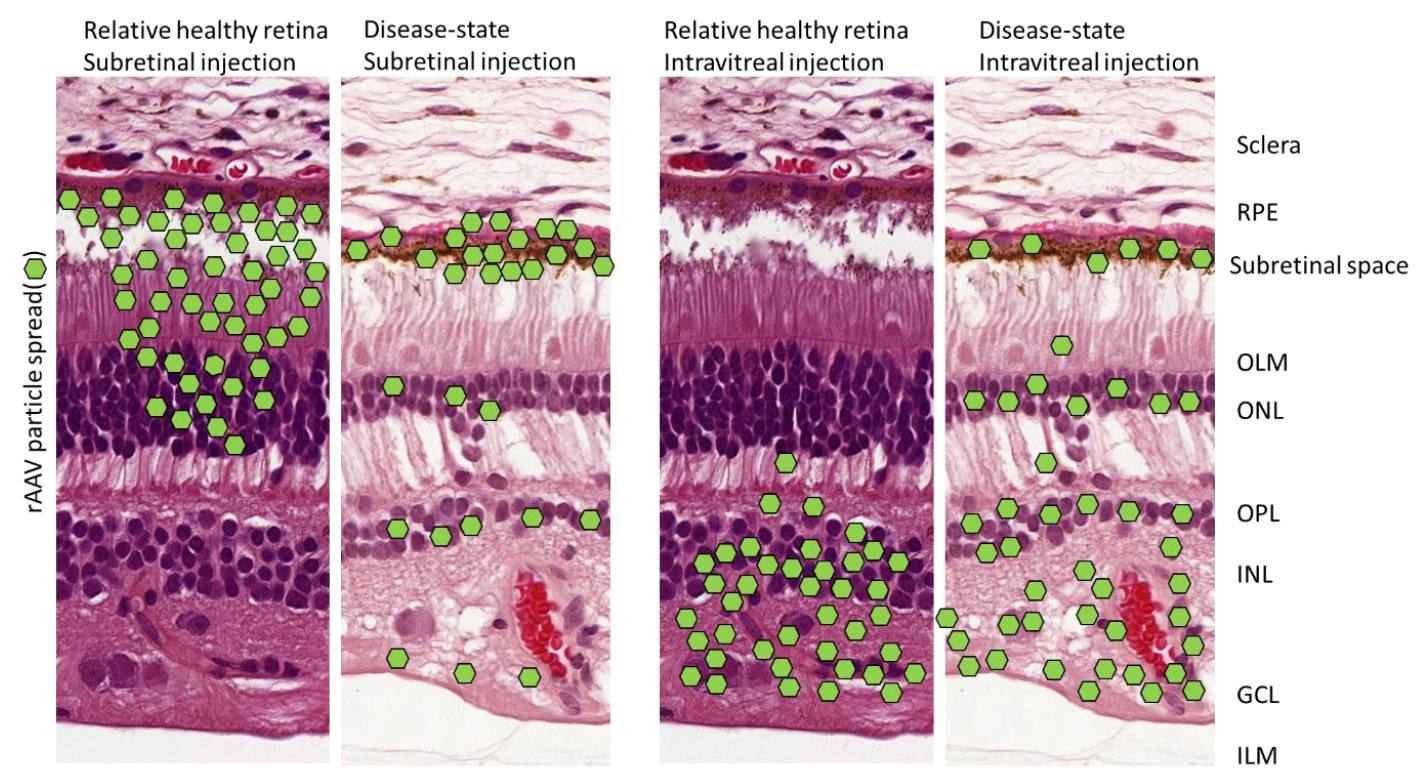

Figure 5. A hypothetical model of the spread of rAAV capsids (serotypes 1, 2, 5 8, and 9) after intravitreal or subretinal injection in disease or non-disease mouse retinas in vivo based on the studies [99,294,304,306,308,309]. RPE, retinal pigment epithelium; OLM, outer limiting membrane, ONL, outer nuclear layer; OPL, outer plexiform layer; INL, inner nuclear layer; GCL, ganglion cell layer; ILM, Inner Limiting Membrane.

\subsubsection{Nonhuman Primate Studies and rAAV Infection}

Several rAAV serotypes are studied for safety/toxicological assessment in retinas of nonhuman primates (NHP) before entering clinical trials. Some information on tropism and promoter cell specificity has been acquired. Subretinal injection (ubiquitous promoter): rAAV1, rAAVrh64R1, rAAV2, rAAV2-7m8, rAAV5, rAAVrh8R, rAAV7, rAAV8, rAAV8BP2, rAAV9, rAnc80L65 infect rod photoreceptors and RPE cells [280,293,316-320]. rAAV8BP2, rAAV9 and rAAV5 infect cone photoreceptors more efficiently than rAAV2 [318,319,321]. Novel AAV capsids, such as the rAAV7m8 and rAAV8BP2, also infected some INL cells and ganglion cells [50,319]. High titer rAnc80L65 and rAAV5 might infect some NHP Müller glial cells [320]. Intravitreal injection (ubiquitous promoter): rAAV2 infects Müller glial cells and ganglion cells [322]. rAAV2-7m8 infects well Müller glial cells and retinal ganglion cells, whereas rAAV8BP2 infects ganglion cells. Self-complementary rAAV2tYFinfects Müller glial cells, at least if the ILM is peeled off before injection [323]. rAAVrh-10 showed promise in transducing the whole rabbit retina and patches of RPE cells, including photoreceptors [310].

Different cell-type-specific promoters have been tested by subretinal or intravitreal injection in NHPs with surprising results. The hGRK1 promoter expressed GFP specifically in rod- and cone photoreceptors [321]. The strong cone-specific promoters in mice (mCAR, PR2.1, and PR1.7) all showed some rod expression and strong cone expression. However, the mouse cone arrestin promoter (mCAR) also expressed eGFP in rods, inner nuclear layer cells, and ganglion cells [293]. A large scale study compared novel synthetic cell-specific promoters using previously described rAAV serotypes (AAV8, AAV9, AAV8BP2) between mice, NHPs, and human retinal explants [50]. Unsurprisingly, NHP and human retinal explants matched closer (correlation $r=0.66-0.67$ ) compared to mouse/NHP or mouse/human $(\mathrm{r}=0.34-0.38 ; \mathrm{r}=0.24-0.32)$. However, a predictive value mean correlation of 0.3 demands that rAAVs and cell-specific promoters need to be tested in human systems. Nevertheless, if an rAAV vector expressed well in human retinal explants and NHP, then it is more likely (conditional probability $=0.12-0.14$ ) that the $\mathrm{AAAV}$ vector works as well in the mouse retina. The results suggest, therefore, that mouse retina can be used to pre-screen rAAV vectors for cell-type specificity. 


\subsubsection{Cis-Regulatory Toxicity of rAAV Vectors In Vivo?}

AAV retinal-specific promoters were compared by subretinal injection at P0 for cis-regulatory sequence toxicity in the CD-1 albino mouse line [324]. This CD-1 mouse line is prone to hearing and vision loss, whereas albino mice are more susceptible to light-induced retinal damage [325]. The encapsidated rAAV vectors containing cis-regulatory ubiquitous promoters (CMV, CAG) or the RPE-specific promoter (hBEST1) showed higher dose-dependent toxicity to the RPE and photoreceptors than photoreceptor-specific promoters (Rho; RedO, CAR, GRK1). The ubiquitous UbC promoter showed no toxicity to the mouse RPE [324]. Interestingly, C57BL/6J mouse retinas injected with AAV8- or AAV5-CMV-GFP at P0 and subsequently analyzed at P30 showed RPE aberrations by SD-OCT but no ERG or OKT differences at $3 \times 10^{9}$ vector genome copies [324]. However, stronger rAAV vectors such as the ones that contain a CMV promoter and a WPRE element such as the vector rAAV2/8.CMV.eGFP.WPRE.bGHpolyA caused retinal degeneration in mice at $5 \times 10^{10} \mathrm{vg}$ (ONL reduction and ERG) [326].

Interestingly, photoreceptor cells that were infected by rAAVs carrying a non-coding gene cassette (rAAV-flox vector) that is floxed out in Cre recombinase expressing cells also caused toxicity at $1 \times 10^{11} \mathrm{vg}$ or above, indicating that the rAAV-capsid can cause toxicity [326]. Further, the ubiquitous CAG promoter caused more toxicity than the rhodopsin specific promoter. Thus, further studies on how promoters might activate the innate immune system by TLR2 or TLR- 9 activation, what sequence motifs are more prone to induce toxicity, or what time points are especially sensitive are of great importance. However, antigen-presenting cells can take up capsids and express the antigens on MHC class II receptors that can activate $\mathrm{CD} 4^{+}$T-helper cells releasing cytokines that stimulate $\mathrm{CD} 8^{+}$ T-cells. This immune cascade model might explain why re-administration in patients could become difficult, and why the administration of rAAVs in patients with high neutralizing antibodies (nAbs) are generally not included in clinical trials [327]. However, the innate, humoral, and cell-mediated immune response might contribute to vector toxicity. For example, intravitreally injected empty rAAV capsids can induce a transient inflammation of the aqueous and the vitreous body [303]. Most importantly, cis-regulatory-sequence, rAAV-capsid, and transgene-related toxicity need to be investigated in the retinal degeneration model. Further, the more efficient gene expression cassettes might allow a rescue strategy at lower rAAV titers, thereby causing less toxicity and lower transient inflammation [303].

\section{Concluding Remarks and Future Prospects}

The tools for modulating rAAV gene therapy vectors are expanding rapidly. Novel rAAV capsids, production platforms, (short) promoters, stabilizing introns, and polyadenylation sequences are being continuously developed and made available in publications and patents. However, many papers on rAAV ocular trials do not sufficiently describe the elements on the plasmid used for the viral vector production (bacterial origin, bacterial selection markers). The vast expanse of rAAV vectors and the poor description of the production process and gene cassette elements make a fair comparison of rAAV vector elements very challenging. Large-scale comparative rAAV element studies are missing in ophthalmology but recent studies indicate that:

1. The use of tyrosine-mutated rAAV2 capsids (AAV2-tYF; AAV2-7m8) increases retinal penetration and infection potentially replacing wild-type capsids (Sections 2 and 5.6).

2. The strong viral promoter CAG expresses the transgenes in the RPE for many years without being silenced [22] (Sections 2, 3 and 5.6).

3. Native promoters are more prone to differ in transgene expression levels in healthy-vs-disease states (Sections 3.4 and 5).

4. Promoters in general can greatly differ within in vivo/in vitro/ex vivo models, as well as across species (Sections 3.4 and 5.6).

5. Inducible promoters (riboswitches and dead-Cas9) offer exciting opportunities to control protein expression (Section 3.8). 
6. Surrogate gene (homolog/ortholog or synthetic) and minigene supplementation may circumvent cellular immunogenicity (Section 4.1).

7. The rAAV production cell line and production cell line related impurities can influence the transduction efficiency in target tissue [44] (Sections 2 and 4.4).

8. Inverted terminal repeats of $\mathrm{rAAVs}$ are essential for high production yields but is not a prerequisite for the efficient transgene expression (Section 4.4.2).

9. Genome integrations of rAAV vectors and the potential cell-toxic effect of genome integrations have been insufficiently studied in retinal tissue (Section 4.4.3).

10. The rAAV infection pathway can vastly differ depending on the selected medium composition, the culturing technique/protocol, and the studied developmental state of the tissue (Section 5.6.1).

11. The disease state strongly influences $\mathrm{rAAV}$-vector penetration, potency, and tropism of the retina (Section 5.6.2).

A large panel of models are available for studying retinal diseases, however, all models have inherent drawbacks. We believe that improved models will become available, allowing more rapid screening of a library of rAAV promoters and rAAV capsids in human systems of high biological relevance (Figure 6, Sections 5.1-5.6).

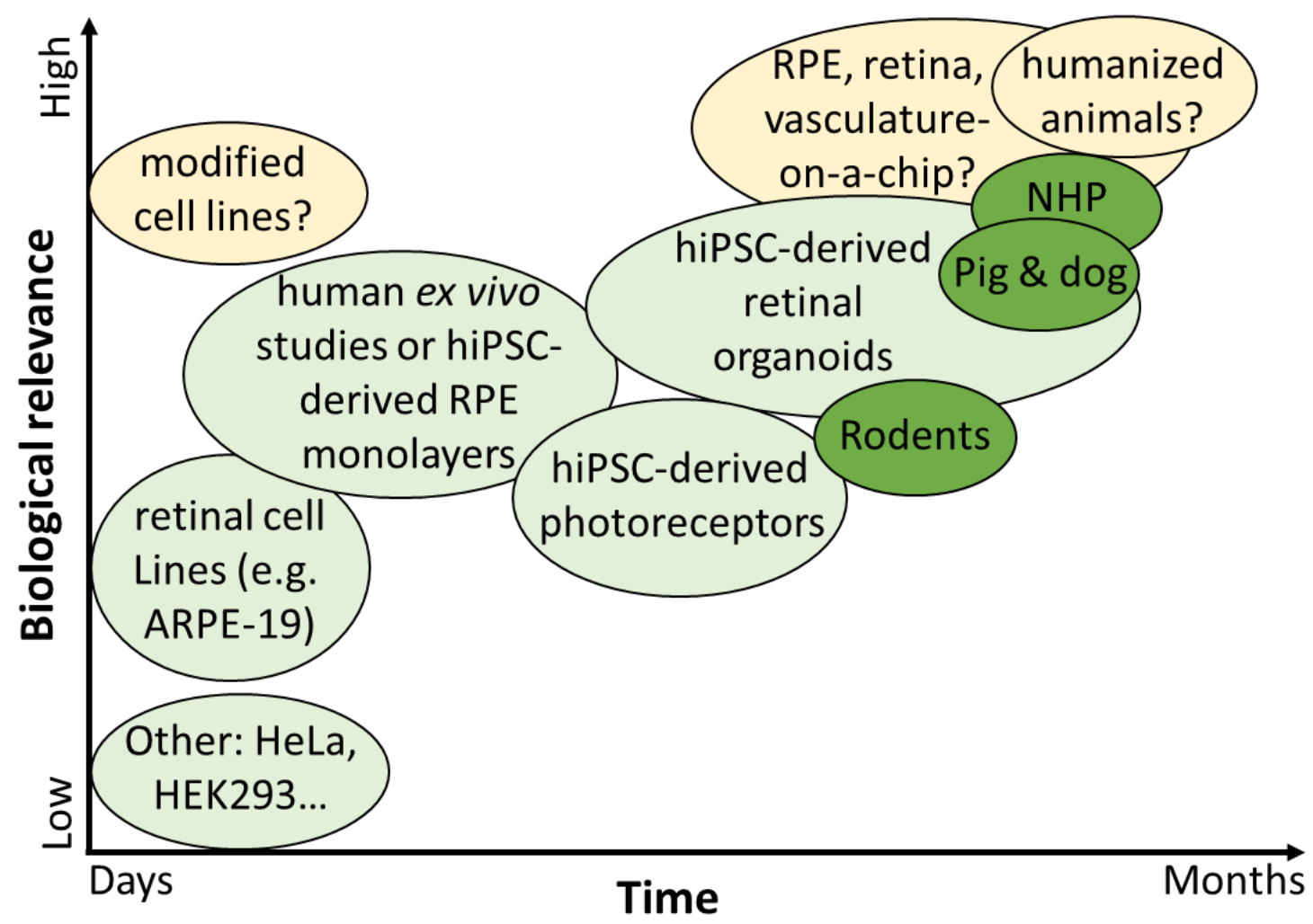

Figure 6. Qualitative assessment of biological relevance and time of assay for retina-specific $\mathrm{rAAV}$ potency assay models. Abbreviations: hiPSC, human induced pluripotent stem cell; NHP, non-human primates; RPE, retinal pigment epithelium.

\section{Material and Methods}

\subsection{A Meta-Analysis on Pro-Viral Plasmids and Production Platforms for Ocular rAAV Therapies in Clinical Trials}

First we collected clinical trial identifiers from reviews on ocular gene therapy. Then, we searched for the keywords (AAV, gene therapy, retinitis pigmentosa, RP, Leber congenital amaurosis, LCA, AMD, CHM) on https://clinicaltrials.gov/ (last date 01 April 2020). The search was limited to ocular 
gene therapies. We further cross-checked the compiled list with reported clinical trials in the news as well as in current reviews. If sequences or $\mathrm{rAAV}$ production platforms were insufficiently reported in research papers the search was broadened to: (1) Ph.D. theses; (2) patents selected based on researchers and companies involved; (3) company registration documents (SEC filings); (4) company websites; (5) company-provided presentations; (6) results presented in international research conferences, and (7) abstracts from international research conferences. Any related information is listed in the supplementary. We matched clinical trial identifiers to each unique rAAV product. Lentiviral products, cell therapy products, antibodies, and antisense oligonucleotide (AONs) products were removed from Figure 3 and Table 1 to include only rAAV-based therapies. All the unique rAAV ocular gene therapy products were then analyzed concerning prokaryotic plasmid backbone, inverted terminal repeat AAV serotype, enhancers, promoters, introns, cDNA genes, codon-optimization, human or other species-related sequences, post-transcriptional stabilizing sequences, polyadenylation sequences, and rAAV production platform. Any missing information is indicated as "UntoldR" or by a "?". The data was curated in MS Excel (Microsoft software) and then loaded in GraphPad Prism version 7 (GraphPad software). Figures 1, 2, 4 and 5 were generated in MS PowerPoint (Microsoft software). All figures were exported as vector graphs and imported in Photoshop (Adobe Software) for final type-set editing.

\subsection{Statistical Analysis}

Statistical analyses and visualization for Figure 3 was done in GraphPad Prism version 7 (GraphPad software).

Supplementary Materials: Table S1: Description of clinical trial rAAV gene therapy products in ophthalmology/Proviral plasmids. Includes the raw data for the generation of Tables 1-5, Figures 2 and 3.

Author Contributions: Conceptualization, T.M.B. and J.W.; Methodology, T.M.B.; Validation, T.M.B., and J.W.; Formal Analysis, T.M.B.; Investigation, T.M.B.; Resources, J.W.; Data Curation, T.M.B.; Writing-Original Draft Preparation, T.M.B.; Writing-Review and Editing, T.M.B. and J.W.; Visualization, T.M.B.; Supervision, J.W.; Project Administration, J.W.; Funding Acquisition, J.W. All authors have read and agreed to the published version of the manuscript.

Acknowledgments: We would like to thank Nanda Boon and Timo Oosenbrug for their scientific input. This research was funded by Foundation Fighting Blindness [TA-GT-0715-0665-LUMC] and The Netherlands Organization for Health Research and Development [ZonMw grant 43200004].

Conflicts of Interest: The authors declare that the research was conducted without any commercial or financial relationship that could be construed as a potential conflict of interest. The LUMC is owner of a pending patent on the use of CRB2 gene therapy vectors (PCT/NL2014/050549) and receives license income and research funds from HORAMA. J.W. is a full-term employee of LUMC and acts for LUMC as a temporary consultant for HORAMA. J.W. is mentioned as an inventor on the patent application. T.M.B. declares no conflict of interest.

\section{Abbreviations}

\begin{tabular}{|c|c|}
\hline AAV & adeno-associated virus \\
\hline AAV2-tYF & rAAV2-Y444F+Y500F+Y730F \\
\hline Ad & adenovirus \\
\hline AMD & age-related macular degeneration \\
\hline $\mathrm{AON}$ & antisense oligonucleotides \\
\hline BAA & biological activity assay \\
\hline bGH & bovine growth hormone \\
\hline CAG/CBA/pCAGGS & $\begin{array}{l}\text { CMV early enhancer element, promoter of the first exon and the first intron of chicken } \\
\beta \text {-actin gene, splice acceptor of the rabbit } \beta \text {-globin intron }\end{array}$ \\
\hline CB7 & shortened CMV early enhancer element and a chicken $\beta$-actin promoter \\
\hline $\mathrm{CBh}$ & $\begin{array}{l}\text { CMV early enhancer element, a chicken } \beta \text {-actin promoter and a chimeric chicken } \\
\beta \text {-Actin/minute virus of mice (MVM) viral protein (VP) intron }\end{array}$ \\
\hline
\end{tabular}




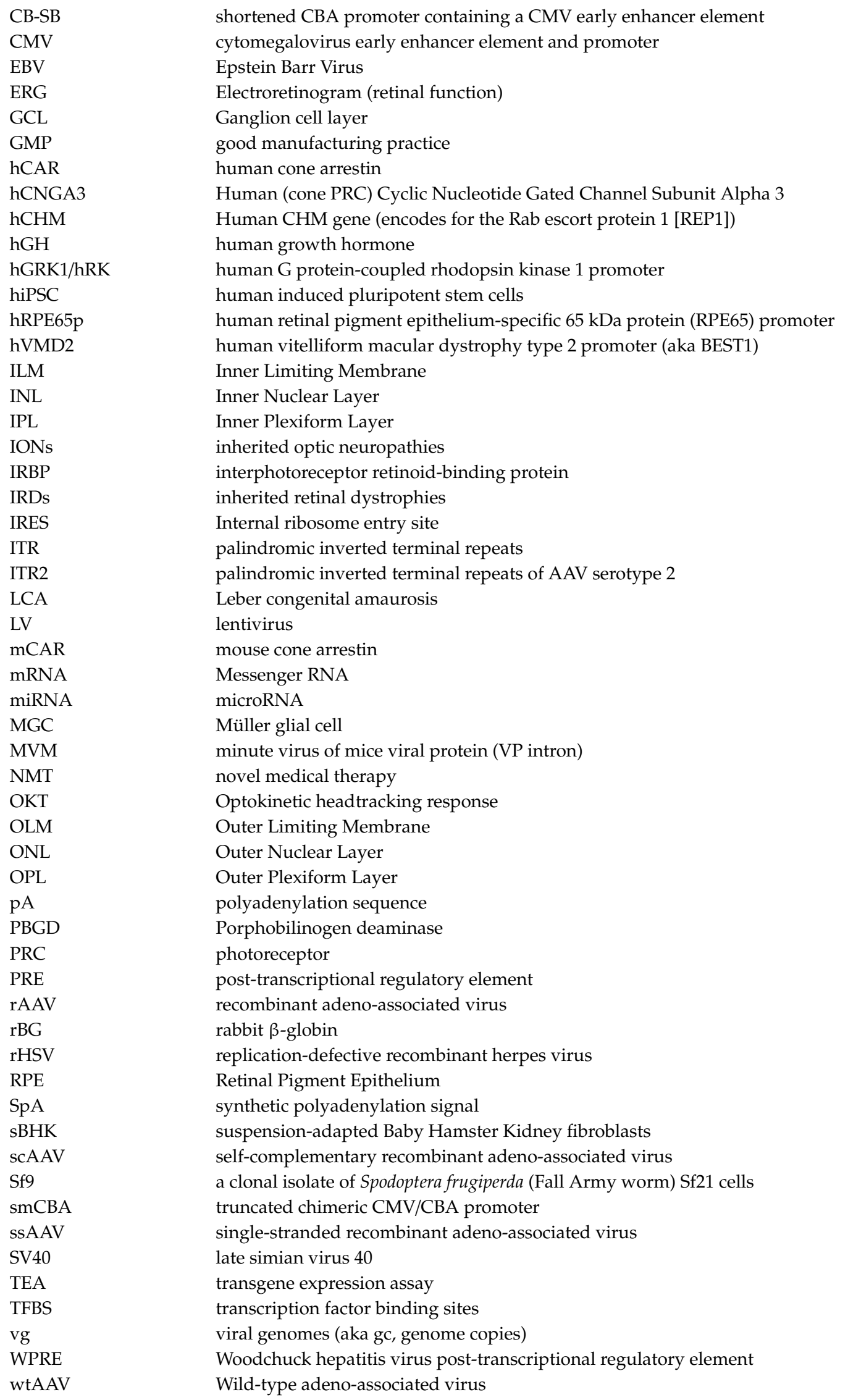




\section{References}

1. Rodrigues, G.A.; Shalaev, E.; Karami, T.K.; Cunningham, J.; Slater, N.K.H.; Rivers, H.M. Pharmaceutical Development of AAV-Based Gene Therapy Products for the Eye. Pharm. Res. 2019, 36. [CrossRef] [PubMed]

2. Boye, S.L.S.E.; Boye, S.L.S.E.; Lewin, A.S.; Hauswirth, W.W. A comprehensive review of retinal gene therapy. Mol. Ther. 2013, 21, 509-519. [CrossRef] [PubMed]

3. Vandenberghe, L.H.; Wilson, J.M.; Gao, G. Tailoring the AAV vector capsid for gene therapy. Gene Ther. 2009, 16, 311-319. [CrossRef]

4. Wang, D.; Tai, P.W.L.; Gao, G. Adeno-associated virus vector as a platform for gene therapy delivery. Nat. Rev. Drug Discov. 2019, 18, 358-378. [CrossRef]

5. Cheever, T.R.; Berkley, D.; Braun, S.; Brown, R.H.; Byrne, B.J.; Chamberlain, J.S.; Cwik, V.; Duan, D.; Federoff, H.J.; High, K.A.; et al. Perspectives on Best Practices for Gene Therapy Programs. Hum. Gene Ther. 2015, 26, 127-133. [CrossRef]

6. Lipinski, D.M.; Thake, M.; Maclaren, R.E. Clinical applications of retinal gene therapy. Prog. Retin. Eye Res. Clin. Appl. Retin. Gene Ther. 2013, 32, 22-47. [CrossRef]

7. McClements, M.E.; MacLaren, R.E. Gene therapy for retinal disease. Transl. Res. 2013, 161, $241-254$. [CrossRef] [PubMed]

8. Smith, A.J.; Bainbridge, J.W.; Ali, R.R. Prospects for retinal gene replacement therapy. Trends Genet. 2009, 25, 156-165. [CrossRef]

9. Bainbridge, J.W.B.; Tan, M.H.; Ali, R.R. Gene therapy progress and prospects: The eye. Gene Ther. 2006, 13, 1191-1197. [CrossRef]

10. Duncan, J.L.; Pierce, E.A.; Laster, A.M.; Daiger, S.P.; Birch, D.G.; Ash, J.D.; Iannaccone, A.; Flannery, J.G.; Sahel, J.A.; Zack, D.J.; et al. Inherited retinal degenerations: Current landscape and knowledge gaps. Transl. Vis. Sci. Technol. 2018, 7. [CrossRef]

11. Fahim, A.T.; Daiger, S.P.; Weleber, R.G. Nonsyndromic Retinitis Pigmentosa Overview. Available online: http://www.ncbi.nlm.nih.gov/pubmed/20301590 (accessed on 19 January 2017).

12. Waehler, R.; Russell, S.J.; Curiel, D.T. Engineering targeted viral vectors for gene therapy. Nat. Rev. Genet. 2007, 8, 573-587. [CrossRef] [PubMed]

13. Ma, Y.; Bao, J.; Zhang, Y.; Li, Z.; Zhou, X.; Wan, C.; Huang, L.; Zhao, Y.; Han, G.; Xue, T. Mammalian Near-Infrared Image Vision through Injectable and Self-Powered Retinal Nanoantennae. Cell 2019, 177, 243-255.e15. [CrossRef] [PubMed]

14. Ziccardi, L.; Cordeddu, V.; Gaddini, L.; Matteucci, A.; Parravano, M.; Malchiodi-Albedi, F.; Varano, M. Gene therapy in retinal dystrophies. Int. J. Mol. Sci. 2019, 20, 5722. [CrossRef]

15. Zallocchi, M.; Binley, K.; Lad, Y.; Ellis, S.; Widdowson, P.; Iqball, S.; Scripps, V.; Kelleher, M.; Loader, J.; Miskin, J.; et al. EIAV-based retinal gene therapy in the shaker1 mouse model for usher syndrome type 1B: Development of UshStat. PLoS ONE 2014, 9. [CrossRef] [PubMed]

16. Truran, R.; Buckley, R.; Radcliffe, P.; Miskin, J.; Mitrophanous, K. Virus Purification. U.S. Patent 9169491B2, 27 October 2015.

17. Payne, S.L.; Rausch, J.; Rushlow, K.; Montelaro, R.C.; Issel, C.; Flaherty, M.; Perry, S.; Sellon, D.; Fuller, F. Characterization of infectious molecular clones of equine infectious anaemia virus. J. Gen. Virol. 1994, 75, 425-429. [CrossRef]

18. Kong, J.; Kim, S.-R.R.; Binley, K.; Pata, I.; Doi, K.; Mannik, J.; Zernant-Rajang, J.; Kan, O.; Iqball, S.; Naylor, S.; et al. Correction of the disease phenotype in the mouse model of Stargardt disease by lentiviral gene therapy. Gene Ther. 2008, 15, 1311-1320. [CrossRef]

19. Vázquez-Domínguez, I.; Garanto, A.; Collin, R.W.J. Molecular Therapies for Inherited Retinal Diseases-Current Standing, Opportunities and Challenges. Genes 2019, 10, 654. [CrossRef]

20. Aschauer, D.F.; Kreuz, S.; Rumpel, S. Analysis of Transduction Efficiency, Tropism and Axonal Transport of AAV Serotypes 1, 2, 5, 6, 8 and 9 in the Mouse Brain. PLoS ONE 2013, 8. [CrossRef]

21. Duong, T.T.; Lim, J.; Vasireddy, V.; Papp, T.; Nguyen, H.; Leo, L.; Pan, J.; Zhou, S.; Chen, I.; Bennett, J.; et al. Comparative AAV-EGFP transgene expression using vector serotypes 1-9, 7M8, and $8 \mathrm{~b}$ in human pluripotent stem cells, RPEs, and human and rat cortical neurons. Stem Cells Int. 2019, 2019. [CrossRef] 
22. Gardiner, K.L.; Cideciyan, A.V.; Swider, M.; Dufour, V.L.; Sumaroka, A.; Komáromy, A.M.; Hauswirth, W.W.; Iwabe, S.; Jacobson, S.G.; Beltran, W.A.; et al. Long-term Structural Outcomes of Late-stage RPE65 Gene Therapy. Mol. Ther. 2020, 28, 266-278. [CrossRef] [PubMed]

23. Schnepp, B.C.; Clark, K.R.; Klemanski, D.L.; Pacak, C.A.; Johnson, P.R. Genetic Fate of Recombinant Adeno-Associated Virus Vector Genomes in Muscle. J. Virol. 2003, 77, 3495-3504. [CrossRef] [PubMed]

24. Pellissier, L.P.; Hoek, R.M.; Vos, R.M.; Aartsen, W.M.; Klimczak, R.R.; Hoyng, S.A.; Flannery, J.G.; Wijnholds, J. Specific tools for targeting and expression in Müller glial cells. Mol. Ther.-Methods Clin. Dev. 2014, 1, 14009. [CrossRef] [PubMed]

25. Koerber, J.T.; Klimczak, R.; Jang, J.-H.H.; Dalkara, D.; Flannery, J.G.; Schaffer, D.V. Molecular evolution of adeno-associated virus for enhanced glial gene delivery. Mol. Ther. 2009, 17, 2088-2095. [CrossRef]

26. Pleticha, J.; Heilmann, L.F.; Evans, C.H.; Asokan, A.; Samulski, R.J.; Beutler, A.S. Preclinical toxicity evaluation of AAV for pain: Evidence from human AAV studies and from the pharmacology of analgesic drugs. Mol. Pain 2014, 10. [CrossRef]

27. Calcedo, R.; Wilson, J.M. Humoral Immune Response to AAV. Front. Immunol. 2013, 4. [CrossRef]

28. Tan, M.H.; Smith, A.J.; Pawlyk, B.; Xu, X.; Liu, X.; Bainbridge, J.B.; Basche, M.; McIntosh, J.; Tran, H.V.; Nathwani, A.; et al. Gene therapy for retinitis pigmentosa and Leber congenital amaurosis caused by defects in AIPL1: Effective rescue of mouse models of partial and complete Aipl1 deficiency using AAV2/2 and AAV2/8 vectors. Hum. Mol. Genet. 2009, 18, 2099-2114. [CrossRef]

29. Francis, P.J. Genetics of inherited retinal disease. J. R. Soc. Med. 2006, 99, 189-191. [CrossRef]

30. Den Hollander, A.I.; Black, A.; Bennett, J.; Cremers, F.P.M. Lighting a candle in the dark: Advances in genetics and gene therapy of recessive retinal dystrophies. J. Clin. Investig. 2010, 120, 3042-3053. [CrossRef]

31. Daiger, S.; Sullivan, L.; Bowne, S. RetNet. Available online: https://sph.uth.edu/retnet/sum-dis.htm\#A-genes (accessed on 11 June 2020).

32. Schachat, A.P.; Maumenee, I.H. Bardet-Biedl Syndrome and Related Disorders. Arch. Ophthalmol. 1982, 100, 285-288. [CrossRef]

33. Bocquet, B.; Lacroux, A.; Surget, M.-O.; Baudoin, C.; Marquette, V.; Manes, G.; Hebrard, M.; Sénéchal, A.; Delettre, C.; Roux, A.-F.; et al. Relative frequencies of inherited retinal dystrophies and optic neuropathies in Southern France: Assessment of 21-year data management. Ophthalmic Epidemiol. 2013, 20, 13-25. [CrossRef] [PubMed]

34. Lei, B.; Zhang, K.; Yue, Y.; Ghosh, A.; Duan, D. Retinal Degenerative Diseases; Spring: New York, NY, USA, 2010; Volume 664, pp. 671-678.

35. Bainbridge, J.W.B.; Smith, A.J.; Barker, S.S.; Robbie, S.; Henderson, R.; Balaggan, K.; Viswanathan, A.; Holder, G.E.; Stockman, A.; Tyler, N.; et al. Effect of gene therapy on visual function in Leber's congenital amaurosis. N. Engl. J. Med. 2008, 358, 2231-2239. [CrossRef] [PubMed]

36. Georgiadis, A.; Duran, Y.; Ribeiro, J.; Abelleira-Hervas, L.; Robbie, S.J.; Sünkel-Laing, B.; Fourali, S.; Gonzalez-Cordero, A.; Cristante, E.; Michaelides, M.; et al. Development of an optimized AAV2/5 gene therapy vector for Leber congenital amaurosis owing to defects in RPE65. Gene Ther. 2016, 23, 857-862. [CrossRef]

37. Samulski, R.J.; Berns, K.I.; Tan, M.; Muzyczka, N. Cloning of adeno-associated virus into pBR322: Rescue of intact virus from the recombinant plasmid in human cells. Proc. Natl. Acad. Sci. USA 1982, 79, 2077-2081. [CrossRef] [PubMed]

38. Laughlin, C.A.; Tratschin, J.D.; Coon, H.; Carter, B.J. Cloning of infectious adeno-associated virus genomes in bacterial plasmids. Gene 1983, 23, 65-73. [CrossRef]

39. Bennett, J. Gene Therapy for Leber's Congenital Amaurosis Due to RPE65 Mutations. In Gene-and Cell-Based Treatment Strategies for the Eye; Rakoczy, E.P., Ed.; Springer: Berlin/Heidelberg, Germany, 2015; pp. 9-25, ISBN 978-3-662-45187-8.

40. Yang, S.; Ma, S.Q.; Wan, X.; He, H.; Pei, H.; Zhao, M.J.; Chen, C.; Wang, D.W.; Dong, X.Y.; Yuan, J.J.; et al. Long-term outcomes of gene therapy for the treatment of Leber's hereditary optic neuropathy. EBioMedicine 2016, 10, 258-268. [CrossRef] [PubMed]

41. Grishanin, R.; Vuillemenot, B.; Sharma, P.; Keravala, A.; Greengard, J.; Gelfman, C.; Blumenkrantz, M.; Lawrence, M.; Hu, W.; Kiss, S.; et al. Preclinical Evaluation of ADVM-022, a Novel Gene Therapy Approach to Treating Wet Age-Related Macular Degeneration. Mol. Ther. 2019, 27, 118-129. [CrossRef] 
42. Ye, G.; Budzynski, E.; Sonnentag, P.; Nork, T.M.; Miller, P.E.; Sharma, A.K.; Ver Hoeve, J.N.; Smith, L.M.; Arndt, T.; Calcedo, R.; et al. Safety and Biodistribution Evaluation in Cynomolgus Macaques of rAAV2tYF-PR1.7-hCNGB3, a Recombinant AAV Vector for Treatment of Achromatopsia. Hum. Gene Ther. Clin. Dev. 2016, 27, 37-48. [CrossRef]

43. Song, C.; Conlon, T.J.; Deng, W.T.; Coleman, K.E.; Zhu, P.; Plummer, C.; Mandapati, S.; Van Hoosear, M.; Green, K.B.; Sonnentag, P.; et al. Toxicology and pharmacology of an AAV vector expressing codon-optimized RPGR in RPGR-deficient Rd9 mice. Hum. Gene Ther. Clin. Dev. 2018, 29, 188-197. [CrossRef]

44. Rumachik, N.G.; Malaker, S.A.; Poweleit, N.; Maynard, L.H.; Adams, C.M.; Leib, R.D.; Cirolia, G.; Thomas, D.; Stamnes, S.; Holt, K.; et al. Methods Matter-Standard Production Platforms For Recombinant AAV Can Produce Chemically And Functionally Distinct Vectors. bioRxiv 2019, 640169.

45. Smale, S.T.; Kadonaga, J.T. The RNA Polymerase II Core Promoter. Annu. Rev. Biochem. 2003, 72, 449-479. [CrossRef] [PubMed]

46. Chanda, D.; Hensel, J.A.; Higgs, J.T.; Grover, R.; Kaza, N.; Ponnazhagan, S. Effects of cellular methylation on transgene expression and site-specific integration of adeno-associated virus. Genes 2017, 8, 232. [CrossRef] [PubMed]

47. Faust, S.M.; Bell, P.; Cutler, B.J.; Ashley, S.N.; Zhu, Y.; Rabinowitz, J.E.; Wilson, J.M. CpG-depleted adeno-associated virus vectors evade immune detection. J. Clin. Investig. 2013, 123, 2994-3001. [CrossRef] [PubMed]

48. Even, D.Y.; Kedmi, A.; Basch-Barzilay, S.; Ideses, D.; Tikotzki, R.; Shir-Shapira, H.; Shefi, O.; Juven-Gershon, T. Engineered promoters for potent transient overexpression. PLoS ONE 2016, 11. [CrossRef]

49. Hartl, D.; Schübeler, D.; Roska, B.; Krebs, A.; Jüttner, J. Synp161, a Promoter for the Specific Expression of Genes in Rod Photoreceptors. WO2017093935A1, 8 June 2017.

50. Jüttner, J.; Szabo, A.; Gross-Scherf, B.; Morikawa, R.K.; Rompani, S.B.; Hantz, P.; Szikra, T.; Esposti, F.; Cowan, C.S.; Bharioke, A.; et al. Targeting neuronal and glial cell types with synthetic promoter AAVs in mice, non-human primates and humans. Nat. Neurosci. 2019, 22, 1345-1356. [CrossRef]

51. Xu, L.; Daly, T.; Gao, C.; Flotte, T.R.; Song, S.; Byrne, B.J.; Sands, M.S.; Parker Ponder, K. CMV-beta-actin promoter directs higher expression from an adeno-associated viral vector in the liver than the cytomegalovirus or elongation factor 1 alpha promoter and results in therapeutic levels of human factor X in mice. Hum. Gene Ther. 2001, 12, 563-573. [CrossRef]

52. Miyazaki, M.; Ikeda, Y.; Yonemitsu, Y.; Goto, Y.; Sakamoto, T.; Tabata, T.; Ueda, Y.; Hasegawa, M.; Tobimatsu, S.; Ishibashi, T.; et al. Simian lentiviral vector-mediated retinal gene transfer of pigment epithelium-derived factor protects retinal degeneration and electrical defect in Royal College of Surgeons rats. Gene Ther. 2003, 10, 1503-1511. [CrossRef]

53. Gilham, D.E.; Lie-A-Ling, M.; Taylor, N.; Hawkins, R.E. Cytokine stimulation and the choice of promoter are critical factors for the efficient transduction of mouse T cells with HIV-1 vectors. J. Gene Med. 2010, 12, 129-136. [CrossRef]

54. Gray, S.J.; Foti, S.B.; Schwartz, J.W.; Bachaboina, L.; Taylor-Blake, B.; Coleman, J.; Ehlers, M.D.; Zylka, M.J.; McCown, T.J.; Samulski, R.J. Optimizing promoters for recombinant adeno-associated virus-mediated gene expression in the peripheral and central nervous system using self-complementary vectors. Hum. Gene Ther. 2011, 22, 1143-1153. [CrossRef]

55. Ohlfest, J.R.; Frandsen, J.L.; Fritz, S.; Lobitz, P.D.; Perkinson, S.G.; Clark, K.J.; Nelsestuen, G.; Key, N.S.; McIvor, R.S.; Hackett, P.B.; et al. Phenotypic correction and long-term expression of factor VIII in hemophilic mice by immunotolerization and nonviral gene transfer using the Sleeping Beauty transposon system. Blood 2005, 105, 2691-2698. [CrossRef] [PubMed]

56. McCown, T.J.; Xiao, X.; Li, J.; Breese, G.R.; Samulski, R.J. Differential and persistent expression patterns of CNS gene transfer by an adeno-associated virus (AAV) vector. Brain Res. 1996, 713, 99-107. [CrossRef]

57. Powell, S.K.; Rivera-Soto, R.; Gray, S.J. Viral expression cassette elements to enhance transgene target specificity and expression in gene therapy. Discov. Med. 2015, 19, 49-57.

58. Klein, R.L.; Meyer, E.M.; Peel, A.L.; Zolotukhin, S.; Meyers, C.; Muzyczka, N.; King, M.A. Neuron-specific transduction in the rat septohippocampal or nigrostriatal pathway by recombinant adeno-associated virus vectors. Exp. Neurol. 1998, 150, 183-194. [CrossRef]

59. Farjo, R.; Skaggs, J.; Quiambao, A.B.; Cooper, M.J.; Naash, M.I. Efficient non-viral ocular gene transfer with compacted DNA nanoparticles. PLoS ONE 2006, 1. [CrossRef] [PubMed] 
60. Pellissier, L.P.; Quinn, P.M.; Henrique Alves, C.; Vos, R.M.; Klooster, J.; Flannery, J.G.; Alexander Heimel, J.; Wijnholds, J. Gene therapy into photoreceptors and Müller glial cells restores retinal structure and function in CRB1 retinitis pigmentosa mouse models. Hum. Mol. Genet. 2015, 24, 3104-3118. [CrossRef] [PubMed]

61. Tsai, Y.T.; Wu, W.H.; Lee, T.T.; Wu, W.P.; Xu, C.L.; Park, K.S.; Cui, X.; Justus, S.; Lin, C.S.; Jauregui, R.; et al. Clustered Regularly Interspaced Short Palindromic Repeats-Based Genome Surgery for the Treatment of Autosomal Dominant Retinitis Pigmentosa. Ophthalmology 2018, 125, 1421-1430. [CrossRef]

62. Quinn, P.M.; Buck, T.M.; Mulder, A.A.; Ohonin, C.; Alves, C.H.; Vos, R.M.; Bialecka, M.; van Herwaarden, T.; van Dijk, E.H.C.C.; Talib, M.; et al. Human iPSC-Derived Retinas Recapitulate the Fetal CRB1 CRB2 Complex Formation and Demonstrate that Photoreceptors and Müller Glia Are Targets of AAV5. Stem Cell Rep. 2019, 12, 906-919. [CrossRef]

63. Niwa, H.; Yamamura, K.; Miyazaki, J. Efficient selection for high-expression transfectants with a novel eukaryotic vector. Gene 1991, 108, 193-199.

64. Wang, Z.; Ma,H.-I.; Li, J.; Sun, L.; Zhang, J.; Xiao, X. Rapid and highly efficient transduction by double-stranded adeno-associated virus vectors in vitro and in vivo. Gene Ther. 2003, 10, 2105-2111. [CrossRef]

65. Sawicki, J.A.; Morris, R.J.; Monks, B.; Sakai, K.; Miyazaki, J. SHORT NOTE A Composite CMV-IE Enhancer/ $\beta$-Actin Promoter Is Ubiquitously Expressed in Mouse Cutaneous Epithelium. Exp. Cell Res. 1998, 244, 367-369. [CrossRef] [PubMed]

66. Koilkonda, R.; Yu, H.; Talla, V.; Porciatti, V.; Feuer, W.J.; Hauswirth, W.W.; Chiodo, V.; Erger, K.E.; Boye, S.L.; Lewin, A.S.; et al. LHON gene therapy vector prevents visual loss and optic neuropathy induced by G11778A mutant mitochondrial DNA: Biodistribution and toxicology profile. Investig. Ophthalmol. Vis. Sci. 2014, 55, 7739-7753. [CrossRef] [PubMed]

67. Bobo, R.H.; Laske, D.W.; Akbasak, A.; Morrison, P.F.; Dedrick, R.L.; Oldfield, E.H. Convection-enhanced delivery of macromolecules in the brain. Proc. Natl. Acad. Sci. USA 1994, 91, 2076-2080. [CrossRef]

68. Rastegar, M.; Hotta, A.; Pasceri, P.; Makarem, M.; Cheung, A.Y.L.; Elliott, S.; Park, K.J.; Adachi, M.; Jones, F.S.; Clarke, I.D.; et al. MECP2 isoform-specific vectors with regulated expression for Rett syndrome gene therapy. PLoS ONE 2009, 4, e6810. [CrossRef]

69. Li, C.; Hirsch, M.; Carter, P.; Asokan, A.; Zhou, X.; Wu, Z.; Samulski, R.J. A small regulatory element from chromosome 19 enhances liver-specific gene expression. Gene Ther. 2009, 16, 43-51. [CrossRef] [PubMed]

70. Gill, D.R.; Smyth, S.E.; Goddard, C.A.; Pringle, I.A.; Higgins, C.F.; Colledge, W.H.; Hyde, S.C. Increased persistence of lung gene expression using plasmids containing the ubiquitin $C$ or elongation factor 1alpha promoter. Gene Ther. 2001, 8, 1539-1546. [CrossRef]

71. Lu, Y.; Krishnan, A.; Brommer, B.; Tian, X.; Meer, M.; Vera, D.L.; Wang, C.; Zeng, Q.; Yu, D.; Bonkowski, M.S.; et al. Reversal of ageing- and injury-induced vision loss by Tet-dependent epigenetic reprogramming. bioRxiv 2019, 710210.

72. Bochkov, Y.A.; Palmenberg, A.C. Translational efficiency of EMCV IRES in bicistronic vectors is dependent upon IRES sequence and gene location. Biotechniques 2006, 41, 283-292. [CrossRef]

73. Attal, J.; Theron, M.C.; Puissant, C.; Houdebine, L.M. Effect of intercistronic length on internal ribosome entry site (IRES) efficiency in bicistronic mRNA. Gene Expr. 1999, 8, 299-309.

74. Al-Allaf, F.A.; Abduljaleel, Z.; Athar, M.; Taher, M.M.; Khan, W.; Mehmet, H.; Colakogullari, M.; Apostolidou, S.; Bigger, B.; Waddington, S.; et al. Modifying inter-cistronic sequence significantly enhances IRES dependent second gene expression in bicistronic vector: Construction of optimised cassette for gene therapy of familial hypercholesterolemia. Non-Coding RNA Res. 2019, 4, 1-14. [CrossRef]

75. Fagoe, N.D.; Eggers, R.; Verhaagen, J.; Mason, M.R.J. A compact dual promoter adeno-associated viral vector for efficient delivery of two genes to dorsal root ganglion neurons. Gene Ther. 2014, 21, 242-252. [CrossRef] [PubMed]

76. Osakada, F.; Takahashi, M. Challenges in retinal circuit regeneration: Linking neuronal connectivity to circuit function. Biol. Pharm. Bull. 2015, 38, 341-357. [CrossRef]

77. Tervo, D.G.R.; Hwang, B.Y.; Viswanathan, S.; Gaj, T.; Lavzin, M.; Ritola, K.D.; Lindo, S.; Michael, S.; Kuleshova, E.; Ojala, D.; et al. A Designer AAV Variant Permits Efficient Retrograde Access to Projection Neurons. Neuron 2016, 92, 372-382. [CrossRef]

78. Dana, H.; Sun, Y.; Mohar, B.; Hulse, B.K.; Kerlin, A.M.; Hasseman, J.P.; Tsegaye, G.; Tsang, A.; Wong, A.; Patel, R.; et al. High-performance calcium sensors for imaging activity in neuronal populations and microcompartments. Nat. Methods 2019, 16, 649-657. [CrossRef] 
79. Nickells, R.W.; Schmitt, H.M.; Maes, M.E.; Schlamp, C.L. AAV2-mediated transduction of the mouse retina after optic nerve injury. Investig. Ophthalmol. Vis. Sci. 2017, 58, 6091-6104. [CrossRef] [PubMed]

80. Garanto, A. RNA-Based Therapeutic Strategies for Inherited Retinal Dystrophies. Adv. Exp. Med. Biol. 2019, 1185, 71-77. [PubMed]

81. Ren, R.; Li, Y.; Liu, Z.; Liu, K.; He, S. Long-term rescue of rat retinal ganglion cells and visual function by AAV-mediated BDNF expression after acute elevation of intraocular pressure. Investig. Ophthalmol. Vis. Sci. 2012, 53, 1003-1011. [CrossRef]

82. LeVaillant, C.J.; Sharma, A.; Muhling, J.; Wheeler, L.P.; Cozens, G.S.; Hellström, M.; Rodger, J.; Harvey, A.R. Significant changes in endogenous retinal gene expression assessed 1 year after a single intraocular injection of AAV-CNTF or AAV-BDNF. Mol. Ther.-Methods Clin. Dev. 2016, 3, 16078. [CrossRef] [PubMed]

83. Lau, D.; McGee, L.H.; Zhou, S.; Rendahl, K.G.; Manning, W.C.; Escobedo, J.A.; Flannery, J.G. Retinal degeneration is slowed in transgenic rats by AAV-mediated delivery of FGF-2. Investig. Ophthalmol. Vis. Sci. 2000, 41, 3622-3633.

84. Leaver, S.G.; Cui, Q.; Plant, G.W.; Arulpragasam, A.; Hisheh, S.; Verhaagen, J.; Harvey, A.R. AAV-mediated expression of CNTF promotes long-term survival and regeneration of adult rat retinal ganglion cells. Gene Ther. 2006, 13, 1328-1341. [CrossRef]

85. Dalkara, D.; Kolstad, K.D.; Guerin, K.I.; Hoffmann, N.V.; Visel, M.; Klimczak, R.R.; Schaffer, D.V.; Flannery, J.G. AAV mediated GDNF secretion from retinal glia slows down retinal degeneration in a rat model of retinitis pigmentosa. Mol. Ther. 2011, 19, 1602-1608. [CrossRef] [PubMed]

86. Osborne, A.; Wang, A.X.Z.; Tassoni, A.; Widdowson, P.S.; Martin, K.R. Design of a Novel Gene Therapy Construct to Achieve Sustained Brain-Derived Neurotrophic Factor Signaling in Neurons. Hum. Gene Ther. 2018, 29, 828-841. [CrossRef] [PubMed]

87. Askou, A.L.; Alsing, S.; Benckendorff, J.N.E.; Holmgaard, A.; Mikkelsen, J.G.; Aagaard, L.; Bek, T.; Corydon, T.J. Suppression of Choroidal Neovascularization by AAV-Based Dual-Acting Antiangiogenic Gene Therapy. Mol. Ther.-Nucleic Acids 2019, 16, 38-50. [CrossRef]

88. Grimm, D.; Streetz, K.L.; Jopling, C.L.; Storm, T.A.; Pandey, K.; Davis, C.R.; Marion, P.; Salazar, F.; Kay, M.A. Fatality in mice due to oversaturation of cellular microRNA/short hairpin RNA pathways. Nature 2006, 441, 537-541. [CrossRef] [PubMed]

89. Vázquez-Chona, F.R.; Clark, A.M.; Levine, E.M. Rlbp1 promoter drives robust Müller glial GFP expression in transgenic mice. Investig. Ophthalmol. Vis. Sci. 2009, 50, 3996-4003. [CrossRef] [PubMed]

90. Hanlon, K.S.; Chadderton, N.; Palfi, A.; Fernandez, A.B.; Humphries, P.; Kenna, P.F.; Millington-Ward, S.; Farrar, G.J. A novel retinal ganglion cell promoter for utility in AAV vectors. Front. Neurosci. 2017, 11. [CrossRef]

91. Khani, S.C.; Pawlyk, B.S.; Bulgakov, O.V.; Kasperek, E.; Young, J.E.; Adamian, M.; Sun, X.; Smith, A.J.; Ali, R.R.; Li, T. AAV-mediated expression targeting of rod and cone photoreceptors with a human rhodopsin kinase promoter. Investig. Ophthalmol. Vis. Sci. 2007, 48, 3954-3961. [CrossRef]

92. Isomura, H.; Stinski, M.F.; Kudoh, A.; Daikoku, T.; Shirata, N.; Tsurumi, T. Two Sp1/Sp3 Binding Sites in the Major Immediate-Early Proximal Enhancer of Human Cytomegalovirus Have a Significant Role in Viral Replication. J. Virol. 2005, 79, 9597-9607. [CrossRef]

93. Dynan, W.S.; Tjian, R. The promoter-specific transcription factor Sp1 binds to upstream sequences in the SV40 early promoter. Cell 1983, 35, 79-87. [CrossRef]

94. Briggs, M.R.; Kadonaga, J.T.; Bell, S.P.; Tjian, R. Purification and biochemical characterization of the promoter-specific transcription factor, Sp1. Science 1986, 234, 47-52. [CrossRef]

95. Hebbard, L.; Steffen, A.; Zawadzki, V.; Fieber, C.; Howells, N.; Moll, J.; Ponta, H.; Hofmann, M.; Sleeman, J. CD44 expression and regulation during mammary gland development and function. J. Cell Sci. 2000, 113, 2619-2630. [PubMed]

96. Su, M.; Hu, H.; Lee, Y.; D’Azzo, A.; Messing, A.; Brenner, M. Expression Specificity of GFAP Transgenes. Neurochem. Res. 2004, 29, 2075-2093. [CrossRef] [PubMed]

97. Prentice, H.M.; Biswal, M.R.; Dorey, C.K.; Blanks, J.C. Hypoxia-regulated retinal glial cell-specific promoter for potential gene therapy in disease. Investig. Ophthalmol. Vis. Sci. 2011, 52, 8562-8570. [CrossRef] [PubMed]

98. Kim, D.S.; Matsuda, T.; Cepko, C.L. A core paired-type and POU homeodomain-containing transcription factor program drives retinal bipolar cell gene expression. J. Neurosci. 2008, 28, 7748-7764. [CrossRef] 
99. Aartsen, W.M.; van Cleef, K.W.R.R.; Pellissier, L.P.; Hoek, R.M.; Vos, R.M.; Blits, B.; Ehlert, E.M.E.E.; Balaggan, K.S.; Ali, R.R.; Verhaagen, J.; et al. GFAP-driven GFP expression in activated mouse Müller glial cells aligning retinal blood vessels following intravitreal injection of AAV2/6 vectors. PLOS ONE 2010, 5, e12387. [CrossRef]

100. Dorrell, M.I.; Aguilar, E.; Jacobson, R.; Yanes, O.; Gariano, R.; Heckenlively, J.; Banin, E.; Ramirez, G.A.; Gasmi, M.; Bird, A.; et al. Antioxidant or neurotrophic factor treatment preserves function in a mouse model of neovascularization-associated oxidative stress. J. Clin. Investig. 2009, 119, 611-623. [CrossRef]

101. Choi, V.; Bigelow, C.E.; Dryja, T.P.; Police, S.R. Viral Vectors for the Treatment of Retinal Dystrophy. U.S. Patent 9163259B2, 7 November 2013.

102. Dougherty, C.J.; Smith, G.W.; Dorey, C.K.; Prentice, H.M.; Webster, K.A.; Blanks, J.C. Robust hypoxia-selective regulation of a retinal pigment epithelium-specific adeno-associated virus vector. Mol. Vis. 2008, 14, 471-480.

103. Foster, L.C.; Wiesel, P.; Huggins, G.S.; Pañares, R.; Chin, M.T.; Pellacani, A.; Perrella, M.A. Role of activating protein-1 and high mobility group-I(Y) protein in the induction of CD44 gene expression by interleukin-1 $\beta$ in vascular smooth muscle cells. Faseb J. 2000, 14, 368-378. [CrossRef]

104. Ichsan, A.M.; Kato, I.; Yoshida, T.; Takasawa, K.; Hayasaka, S.; Hiraga, K. Rhodopsin promoter-EGFP fusion transgene expression in photoreceptor neurons of retina and pineal complex in mice. Neurosci. Lett. 2005, 379, 138-143. [CrossRef]

105. Allocca, M.; Mussolino, C.; Garcia-Hoyos, M.; Sanges, D.; Iodice, C.; Petrillo, M.; Vandenberghe, L.H.; Wilson, J.M.; Marigo, V.; Surace, E.M.; et al. Novel adeno-associated virus serotypes efficiently transduce murine photoreceptors. J. Virol. 2007, 81, 11372-11380. [CrossRef] [PubMed]

106. Komáromy, A.M.; Alexander, J.J.; Cooper, A.E.; Chiodo, V.A.; Glushakova, L.G.; Acland, G.M.; Hauswirth, W.W.; Aguirre, G.D. Targeting gene expression to cones with human cone opsin promoters in recombinant AAV. Gene Ther. 2008, 15, 1049-1055. [CrossRef] [PubMed]

107. Quiambao, A.B.; Peachey, N.S.; Mangini, N.J.; Röhlich, P.; Hollyfield, J.G.; Al-Ubaidi, M.R. A 221-bp fragment of the mouse opsin promoter directs expression specifically to the rod photoreceptors of transgenic mice. Vis. Neurosci. 1997, 14, 617-625. [CrossRef] [PubMed]

108. Young, J.E. A Short, Highly Active Photoreceptor-Specific Enhancer/Promoter Region Upstream of the Human Rhodopsin Kinase Gene. Investig. Ophthalmol. Vis. Sci. 2003, 44, 4076-4085. [CrossRef]

109. Sun, X.; Pawlyk, B.; Xu, X.; Liu, X.; Bulgakov, O.V.; Adamian, M.; Sandberg, M.A.; Khani, S.C.; Tan, M.-H.; Smith, A.J.; et al. Gene therapy with a promoter targeting both rods and cones rescues retinal degeneration caused by AIPL1 mutations. Gene Ther. 2010, 17, 117-131. [CrossRef]

110. Beltran, W.A.; Cideciyan, A.V.; Boye, S.E.; Ye, G.-J.; Iwabe, S.; Dufour, V.L.; Marinho, L.F.; Swider, M.; Kosyk, M.S.; Sha, J.; et al. Optimization of Retinal Gene Therapy for X-Linked Retinitis Pigmentosa Due to RPGR Mutations. Mol. Ther. 2017, 25, 1866-1880. [CrossRef]

111. Pang, J.; Deng, W.-T.; Dai, X.; Lei, B.; Everhart, D.; Umino, Y.; Li, J.; Zhang, K.; Mao, S.; Boye, S.L.; et al. AAV-mediated cone rescue in a naturally occurring mouse model of CNGA3-achromatopsia. PLoS ONE 2012, 7, e35250. [CrossRef]

112. Glushakova, L.G.; Timmers, A.M.; Pang, J.; Teusner, J.T.; Hauswirth, W.W. Human blue-opsin promoter preferentially targets reporter gene expression to rat s-cone photoreceptors. Investig. Ophthalmol. Vis. Sci. 2006, 47, 3505-3513. [CrossRef]

113. Michalakis, S.; Mühlfriedel, R.; Tanimoto, N.; Krishnamoorthy, V.; Koch, S.; Fischer, M.D.; Becirovic, E.; Bai, L.; Huber, G.; Beck, S.C.; et al. Restoration of cone vision in the CNGA3-/- mouse model of congenital complete lack of cone photoreceptor function. Mol. Ther. 2010, 18, 2057-2063. [CrossRef]

114. Beltran, W.A.; Cideciyan, A.V.; Lewin, A.S.; Iwabe, S.; Khanna, H.; Sumaroka, A. Gene therapy rescues photoreceptor blindness in dogs and paves the way for treating human X-linked retinitis pigmentosa. Proc. Natl. Acad. Sci. USA 2012, 106, 1-6. [CrossRef]

115. Dyka, F.; Boye, S.; Ryals, R.; Chiodo, V.; Boye, S.; Hauswirth, W. Cone specific promoter for use in gene therapy of retinal degenerative diseases. Adv Exp Med Biol 2014, 801, 695-701. [PubMed]

116. Fischer, M.D.; Michalakis, S.; Wilhelm, B.; Zobor, D.; Muehlfriedel, R.; Kohl, S.; Weisschuh, N.; Ochakovski, G.A.; Klein, R.; Schoen, C.; et al. Safety and Vision Outcomes of Subretinal Gene Therapy Targeting Cone Photoreceptors in Achromatopsia: A Nonrandomized Controlled Trial [published online ahead of print, 30 April 2020]. JAMA Ophthalmol. 2020, 138, 643-651. [CrossRef] [PubMed] 
117. Pickrell, S.W.; Zhu, X.; Wang, X.; Craft, C.M. Deciphering the contribution of known cis-elements in the mouse cone arrestin gene to its cone-specific expression. Investig. Ophthalmol. Vis. Sci. 2004, 45, 3877-3884. [CrossRef]

118. Li, Q.; Timmers, A.M.; Guy, J.; Pang, J.; Hauswirth, W.W. Cone-specific expression using a human red opsin promoter in recombinant AAV. Vis. Res. 2008, 48, 332-338. [CrossRef] [PubMed]

119. Georgiadis, A.; Matsuki, T.; Rizzi, M.; Hoke, J.; Gonzalez-Cordero, A.; Sampson, R.; Bainbridge, J.; Smith, A.; Ali, R. ARVO Annual Meeting Poster A197 Development and efficacy assessment of AAV2/8-hG1.7p.coCNGA3, a CNGA3 gene therapy vector. Investig. Ophthalmol. Vis. Sci. 2019, 60, 3426.

120. Rizzi, M.; Ali, R.; Smith, A.; Nishiguchi, K. Gene Therapy to Improve Vision. U.S. Patent 20180030477A1, 1 February 2018.

121. Forbes, A. United States Securities and Exchange Commission (SEC) Form S-1 Registration Statement MeiraGTx Holdings plc; United States Securities and Exchange Commission: Washington, DC, USA, 2018.

122. Watanabe, S.; Sanuki, R.; Ueno, S.; Koyasu, T.; Hasegawa, T.; Furukawa, T. Tropisms of AAV for Subretinal Delivery to the Neonatal Mouse Retina and Its Application for In Vivo Rescue of Developmental Photoreceptor Disorders. PLoS ONE 2013, 8. [CrossRef]

123. Horsager, A.; Smith, A.; Matteo, B.C. Modulation Neural Pathways. WO 2012/051599 A2, 19 April 2012.

124. Lu, Q.; Ganjawala, T.H.; Ivanova, E.; Cheng, J.G.; Troilo, D.; Pan, Z.H. AAV-mediated transduction and targeting of retinal bipolar cells with improved mGluR6 promoters in rodents and primates. Gene Ther. 2016, 23, 680-689. [CrossRef]

125. Glover, C.P.J.; Bienemann, A.S.; Heywood, D.J.; Cosgrave, A.S.; Uney, J.B. Adenoviral-mediated, high-level, cell-specific transgene expression: A SYN1-WPRE cassette mediates increased transgene expression with no loss of neuron specificity. Mol. Ther. 2002, 5, 509-516. [CrossRef]

126. Dalkara, D.; Picaud, S.; Desrosiers, M.; Sahel, J.-A.; Duebel, J.; Bemelmans, A.; Roska, B. Promoters and uses thereof. U.S. Patent 20180355354A1, 13 December 2018.

127. Simpson, E.M.; Korecki, A.J.; Fornes, O.; McGill, T.J.; Cueva-Vargas, J.L.; Agostinone, J.; Farkas, R.A.; Hickmott, J.W.; Lam, S.L.; Mathelier, A.; et al. New MiniPromoter Ple345 (NEFL) drives strong and specific expression in retinal ganglion cells of mouse and primate retina. Hum. Gene Ther. 2019, 30, $257-272$. [CrossRef] [PubMed]

128. Ali, R.R.; Bainbridge, J.W.B.; Smith, A.J. Devices and Methods for Delivering Polynucleotides into Retinal Cells of the Macula and Fovea. U.S. Patent 20100081707A1, 1 April 2010.

129. Maddalena, A.; Tornabene, P.; Tiberi, P.; Minopoli, R.; Manfredi, A.; Mutarelli, M.; Rossi, S.; Simonelli, F.; Naggert, J.K.; Cacchiarelli, D.; et al. Triple Vectors Expand AAV Transfer Capacity in the Retina. Mol. Ther. 2018, 26, 524-541. [CrossRef] [PubMed]

130. Jüttner, J.; Krol, J.; Roska, B. Synpiii, a Promoter for the Specific Expression of Genes in Retinal Pigment Epithelium. WO2019106035A1, 18 August 2016.

131. Mäkinen, P.I.; Koponen, J.K.; Kärkkäinen, A.M.; Malm, T.M.; Pulkkinen, K.H.; Koistinaho, J.; Turunen, M.P.; Ylä-Herttuala, S. Stable RNA interference: Comparison of U6 and H1 promoters in endothelial cells and in mouse brain. J. Gene Med. 2006, 8, 433-441. [CrossRef] [PubMed]

132. Gao, Z.; Harwig, A.; Berkhout, B.; Herrera-Carrillo, E. Mutation of nucleotides around the +1 position of type 3 polymerase III promoters: The effect on transcriptional activity and start site usage. Transcription 2017, 8, 275-287. [CrossRef]

133. Ong, S.T.; Li, F.; Du, J.; Tan, Y.W.; Wang, S. Hybrid cytomegalovirus enhancer-h1 promoter-based plasmid and baculovirus vectors mediate effective RNA interference. Hum. Gene Ther. 2005, 16, 1404-1412. [CrossRef]

134. Eckenfelder, A.; Tordo, J.; Babbs, A.; Davies, K.E.; Goyenvalle, A.; Danos, O. The Cellular Processing Capacity Limits the Amounts of Chimeric U7 snRNA Available for Antisense Delivery. Mol. Ther. Nucleic Acids 2012, 1, e31. [CrossRef]

135. Salva, M.Z.; Himeda, C.L.; Tai, P.W.; Nishiuchi, E.; Gregorevic, P.; Allen, J.M.; Finn, E.E.; Nguyen, Q.G.; Blankinship, M.J.; Meuse, L.; et al. Design of tissue-specific regulatory cassettes for high-level rAAV-mediated expression in skeletal and cardiac muscle. Mol. Ther. 2007, 15, 320-329. [CrossRef]

136. LaVail, M.M.; Yasumura, D.; Matthes, M.T.; Drenser, K.A.; Flannery, J.G.; Lewin, A.S.; Hauswirth, W.W. Ribozyme rescue of photoreceptor cells in $\mathrm{P} 23 \mathrm{H}$ transgenic rats: Long-term survival and late-stage therapy. Proc. Natl. Acad. Sci. USA 2000, 97, 11488-11493. 
137. Xu, L.; Zhao, L.; Gao, Y.; Xu, J.; Han, R. Empower multiplex cell and tissue-specific CRISPR-mediated gene manipulation with self-cleaving ribozymes and tRNA. Nucleic Acids Res. 2017, 45. [CrossRef]

138. Patrício, M.I.; Barnard, A.R.; Orlans, H.O.; McClements, M.E.; MacLaren, R.E. Inclusion of the Woodchuck Hepatitis Virus Posttranscriptional Regulatory Element Enhances AAV2-Driven Transduction of Mouse and Human Retina. Mol. Ther.-Nucleic Acids 2017, 6, 198-208.

139. Choi, J.-H.; Yu, N.-K.; Baek, G.-C.; Bakes, J.; Seo, D.; Nam, H.J.; Baek, S.H.; Lim, C.-S.; Lee, Y.-S.; Kaang, B.-K. Optimization of AAV expression cassettes to improve packaging capacity and transgene expression iChoi J-H, Yu N-K, Baek G-C, Bakes J, Seo D, Nam HJ, Baek SH, Lim C-S, Lee Y-S, Kaang B-K. 2014. Optimization of AAV expression cassettes to improve packaging. Mol. Brain 2014, 7, 17. [CrossRef] [PubMed]

140. Michalakis, S.; Biel, M.; Seeliger, M.; Schoen, C. Gene Therapy for the Treatment of a Retinal Degeneration Disease. U.S. Patent 20180353620A1, 30 August 2017.

141. Ramezani, A.; Hawley, T.S.; Hawley, R.G. Lentiviral vectors for enhanced gene expression in human hematopoietic cells. Mol. Ther. 2000, 2, 458-469. [CrossRef] [PubMed]

142. Lai, Y.; Yue, Y.; Liu, M.; Duan, D. Synthetic intron improves transduction efficiency of trans-splicing adeno-associated viral vectors. Hum. Gene Ther. 2006, 17, 1036-1042. [CrossRef]

143. Wu, Z.; Sun, J.; Zhang, T.; Yin, C.; Yin, F.; Van Dyke, T.; Samulski, R.J.; Monahan, P.E. Optimization of self-complementary AAV vectors for liver-directed expression results in sustained correction of hemophilia B at low vector dose. Mol. Ther. 2008, 16, 280-289. [CrossRef] [PubMed]

144. Lu, J.; Williams, J.A.; Luke, J.; Zhang, F.; Chu, K.; Kay, M.A. A 5 ' noncoding exon containing engineered intron enhances transgene expression from recombinant AAV vectors in vivo. Hum. Gene Ther. 2017, 28, 125-134. [CrossRef] [PubMed]

145. Karali, M.; Manfredi, A.; Puppo, A.; Marrocco, E.; Gargiulo, A.; Allocca, M.; de Corte, M.; Rossi, S.; Giunti, M.; Bacci, M.L.; et al. MicroRNA-Restricted transgene expression in the retina. PLoS ONE 2011, 6. [CrossRef]

146. Brown, B.D.; Cantore, A.; Annoni, A.; Sergi, L.S.; Lombardo, A.; Della Valle, P.; D’Angelo, A.; Naldini, L. A microRNA-regulated lentiviral vector mediates stable correction of hemophilia B mice. Blood 2007, 110, 4144-4152. [CrossRef]

147. Xie, J.; Mao, Q.; Tai, P.W.L.; He, R.; Ai, J.; Su, Q.; Zhu, Y.; Ma, H.; Li, J.; Gong, S.; et al. Short DNA Hairpins Compromise Recombinant Adeno-Associated Virus Genome Homogeneity. Mol. Ther. 2017, 25, 1363-1374. [CrossRef]

148. Domenger, C.; Grimm, D. Next-generation AAV vectors-Do not judge a virus (only) by its cover. Hum. Mol. Genet. 2019, 28, R3-R14. [CrossRef]

149. Yew, N.S.; Wysokenski, D.M.; Wang, K.X.; Ziegler, R.J.; Marshall, J.; McNeilly, D.; Cherry, M.; Osburn, W.; Cheng, S.H. Optimization of plasmid vectors for high-level expression in lung epithelial cells. Hum. Mol. Genet. 1997, 8, 575-584. [CrossRef] [PubMed]

150. Donello, J.E.; Loeb, J.E.; Hope, T.J. Woodchuck hepatitis virus contains a tripartite posttranscriptional regulatory element. J. Virol. 1998, 72, 5085-5092. [CrossRef] [PubMed]

151. Ronzitti, G.; Collaud, F.; Bortolussi, G.; Charles, S.; Vidal, P.; Sola, M.S.; Muro, A.; Mingozzi, F. 158. Cryptic ATG Removal from Synthetic Introns Increase the Therapeutic Efficacy of AAV Vector Mediated Gene Transfer. Mol. Ther. 2016, 24, S62. [CrossRef]

152. Choi, V.W.; Bigelow, C.E.; McGee, T.L.; Gujar, A.N.; Li, H.; Hanks, S.M.; Vrouvlianis, J.; Maker, M.; Leehy, B.; Zhang, Y.; et al. AAV-mediated RLBP1 gene therapy improves the rate of dark adaptation in Rlbp1 knockout mice. Mol. Ther.-Methods Clin. Dev. 2015, 2, 15022. [CrossRef] [PubMed]

153. Beltran, W.A.; Aguirre, G.D.; Jacobson, S.G.; Cideciyan, A.V.; Lewin, A.S.; Boye, S.L.; Hauswirth, W.W.; Deng, W.-T. AAV-Mediated Gene Therapy for RPGR X-Linked Retinal Degeneration. U.S. Patent 9770491B2, 26 September 2017.

154. Xu, D.H.; Wang, X.Y.; Jia, Y.L.; Wang, T.Y.; Tian, Z.W.; Feng, X.; Zhang, Y.N. SV40 intron, a potent strong intron element that effectively increases transgene expression in transfected Chinese hamster ovary cells. J. Cell. Mol. Med. 2018, 22, 2231-2239. [CrossRef]

155. MacLaren, R.E.; Groppe, M.; Barnard, A.R.; Cottriall, C.L.; Tolmachova, T.; Seymour, L.; Reed Clark, K.; During, M.J.; Cremers, F.P.M.; Black, G.C.M.; et al. Retinal gene therapy in patients with choroideremia: Initial fi ndings from a phase $1 / 2$ clinical trial. Lancet 2014, 383, 1129-1137. [CrossRef] 
156. Jacobson, S.G.; Cideciyan, A.V.; Ratnakaram, R.; Heon, E.; Schwartz, S.B.; Roman, A.J.; Peden, M.C.; Aleman, T.S.; Boye, S.L.; Sumaroka, A.; et al. Gene therapy for leber congenital amaurosis caused by RPE65 mutations: Safety and efficacy in 15 children and adults followed up to 3 years. Arch. Ophthalmol. 2012, 130, 9-24. [CrossRef]

157. Lam, B.L.; Davis, J.L.; Gregori, N.Z.; MacLaren, R.E.; Girach, A.; Verriotto, J.D.; Rodriguez, B.; Rosa, P.R.; Zhang, X.; Feuer, W.J. Choroideremia Gene Therapy Phase 2 Clinical Trial: 24-Month Results. Am. J. Ophthalmol. 2019, 197, 65-73. [CrossRef]

158. Kurachi, S.; Hitomi, Y.; Furukawa, M.; Kurachi, K. Role of intron I in expression of the human factor IX gene. J. Biol. Chem. 1995, 270, 5276-5281. [CrossRef] [PubMed]

159. Kim, J.H.; Lee, S.R.; Li, L.H.; Park, H.J.; Park, J.H.; Lee, K.Y.; Kim, M.K.; Shin, B.A.; Choi, S.Y. High cleavage efficiency of a 2A peptide derived from porcine teschovirus-1 in human cell lines, zebrafish and mice. PLoS ONE 2011, 6. [CrossRef] [PubMed]

160. Urabe, M.; Hasumi, Y.; Ogasawara, Y.; Matsushita, T.; Kamoshita, N.; Nomoto, A.; Colosi, P.; Kurtzman, G.J.; Tobita, K.; Ozawa, K. A novel dicistronic AAV vector using a short IRES segment derived from hepatitis C virus genome. Gene 1997, 200, 157-162. [CrossRef]

161. Eggermont, J.; Proudfoot, N.J. Poly(A) signals and transcriptional pause sites combine to prevent interference between RNA polymerase II promoters. Embo J. 1993, 12, 2539-2548. [CrossRef]

162. Mhyre, A.J.; Marcondes, A.M.; Spaulding, E.Y.; Deeg, H.J.Stroma-dependent apoptosis in clonal hematopoietic precursors correlates with expression of PYCARD. Blood 2009, 113, 649-658. [CrossRef]

163. Satkunanathan, S.; Wheeler, J.; Thorpe, R.; Zhao, Y. Establishment of a novel cell line for the enhanced production of recombinant adeno-associated virus vectors for gene therapy. Hum. Gene Ther. 2014, 25, 929-941. [CrossRef]

164. VectorBuilder Inc. Vectorbuilder.com/Learning-Center/Vector-Component/Promoter. Available online: https://en.vectorbuilder.com/learning-center/vector-component/linker.html (accessed on 11 June 2020).

165. Martinez-Lopez, A.; Encinas, P.; García-Valtanen, P.; Gomez-Casado, E.; Coll, J.M.; Estepa, A. Improving the safety of viral DNA vaccines: Development of vectors containing both $5^{\prime}$ and $3^{\prime}$ homologous regulatory sequences from non-viral origin. Appl. Microbiol. Biotechnol. 2013, 97, 3007-3016. [CrossRef]

166. McFarland, T.J.; Zhang, Y.; Atchaneeyaskul, L.O.; Francis, P.; Stout, J.T.; Appukuttan, B. Evaluation of a novel short polyadenylation signal as an alternative to the SV40 polyadenylation signal. Plasmid 2006, 56, 62-67. [CrossRef]

167. Vora, S.; Cheng, J.; Xiao, R.; VanDusen, N.J.; Quintino, L.; Pu, W.T.; Vandenberghe, L.H.; Chavez, A.; Church, G. Rational design of a compact CRISPR-Cas9 activator for AAV-mediated delivery. bioRxiv 2018, 9 , 298620.

168. Hager, S.; Frame, F.M.; Collins, A.T.; Burns, J.E.; Maitland, N.J. An internal polyadenylation signal substantially increases expression levels of lentivirus-delivered transgenes but has the potential to reduce viral titer in a promoter-dependent manner. Hum. Gene Ther. 2008, 19, 840-850. [CrossRef]

169. Schambach, A.; Galla, M.; Maetzig, T.; Loew, R.; Baum, C. Improving transcriptional termination of self-inactivating gamma-retroviral and lentiviral vectors. Mol. Ther. 2007, 15, 1167-1173. [CrossRef]

170. Ostedgaard, L.S.; Rokhlina, T.; Karp, P.H.; Lashmit, P.; Afione, S.; Schmidt, M.; Zabner, J.; Stinski, M.F.; Chiorini, J.A.; Welsh, M.J. A shortened adeno-associated virus expression cassette for CFTR gene transfer to cystic fibrosis airway epithelia. Proc. Natl. Acad. Sci. USA 2005, 102, 2952-2957. [CrossRef]

171. Kumar-Singh, R.; Leaderer, D.; Cashman, S. Compositions, Kits and Methods for Treatment of Complement-Related Disorders. U.S. Patent 20170209535A1, 16 July 2019.

172. Cole, C.N.; Stacy, T.P. Identification of sequences in the herpes simplex virus thymidine kinase gene required for efficient processing and polyadenylation. Mol. Cell. Biol. 1985, 5, 2104-2113. [CrossRef] [PubMed]

173. Lipinski, D.M. A Comparison of Inducible Gene Expression Platforms: Implications for Recombinant Adeno-Associated Virus (rAAV) Vector-Mediated Ocular Gene Therapy. In Advances in Experimental Medicine and Biology; Bowes Rickman, C., Grimm, C., Anderson, R., Ash, J., LaVail, M., Hollyfield, J.G., Eds.; Springer: Cham, Switzerland, 2019; Volume 1185, pp. 79-83.

174. Peterson, M.G.; Mercer, J.F.B. Structure and regulation of the sheep metallothionein-Ia gene. Eur. J. Biochem. 1986, 160, 579-585. [CrossRef] [PubMed]

175. Grimm, S.L.; Nordeen, S.K. Mouse mammary tumor virus sequences responsible for activating cellular oncogenes. J. Virol. 1998, 72, 9428-9435. [CrossRef] 
176. Yamamoto, K.R. Steroid Receptor Regulated Transcription of Specific Genes and Gene Networks. Annu. Rev. Genet. 1985, 19, 209-252. [CrossRef] [PubMed]

177. Naughton, B.J.; Han, D.D.; Gu, H.H. Fluorescence-based evaluation of shRNA efficacy. Anal. Biochem. 2011, 417, 162-164. [CrossRef] [PubMed]

178. Strobel, B.; Spöring, M.; Klein, H.; Blazevic, D.; Rust, W.; Sayols, S.; Hartig, J.S.; Kreuz, S. High-throughput identification of synthetic riboswitches by barcode-free amplicon-sequencing in human cells. Nat. Commun. 2020, 11, 714. [CrossRef]

179. Reid, C.A.; Nettesheim, E.R.; Connor, T.B.; Lipinski, D.M. Development of an inducible anti-VEGF rAAV gene therapy strategy for the treatment of wet AMD. Sci. Rep. 2018, 8. [CrossRef]

180. Peränen, J.; Rikkonen, M.; Hyvönen, M.; Kääriäinen, L. T7 vectors with modified T7lac promoter for expression of proteins in Escherichia coli. Anal. Biochem. 1996, 236, 371-373. [CrossRef] [PubMed]

181. Cenik, C.; Chua, H.N.; Zhang, H.; Tarnawsky, S.P.; Akef, A.; Derti, A.; Tasan, M.; Moore, M.J.; Palazzo, A.F.; Roth, F.P. Genome analysis reveals interplay between $5^{\prime}$ UTR introns and nuclear mRNA export for secretory and mitochondrial genes. PLoS Genet. 2011, 7, e1001366. [CrossRef]

182. Bonnet, A.; Grosso, A.R.; Elkaoutari, A.; Coleno, E.; Presle, A.; Sridhara, S.C.; Janbon, G.; Géli, V.; de Almeida, S.F.; Palancade, B. Introns Protect Eukaryotic Genomes from Transcription-Associated Genetic Instability. Mol. Cell 2017, 67, 608-621.e6. [CrossRef] [PubMed]

183. Duan, D. Systemic AAV Micro-dystrophin Gene Therapy for Duchenne Muscular Dystrophy. Mol. Ther. 2018, 26, 2337-2356. [CrossRef] [PubMed]

184. England, S.B.; Nicholson, L.V.; Johnson, M.A.; Forrest, S.M.; Love, D.R.; Zubrzycka-Gaarn, E.E.; Bulman, D.E.; Harris, J.B.; Davies, K.E. Very mild muscular dystrophy associated with the deletion of $46 \%$ of dystrophin. Nature 1990, 343, 180-182. [CrossRef]

185. Davies, K.E.; Chamberlain, J.S. Surrogate gene therapy for muscular dystrophy. Nat. Med. 2019, 25, $1473-1474$. [CrossRef]

186. Zhang, W.; Li, L.; Su, Q.; Gao, G.; Khanna, H. Gene Therapy Using a miniCEP290 Fragment Delays Photoreceptor Degeneration in a Mouse Model of Leber Congenital Amaurosis. Hum. Gene Ther. 2018, 29, 42-50. [CrossRef]

187. Dona, M.A. Gene therapy using miniUSH2A genes improves visual function in a zebrafish ush2a knock-out model. In Towards gene therapy for USH2A-associated retinitis pigmentosa. Fishing for answers [Doctoral Thesis]; Kremer, J.M.J., Keunen, J.E.E., van Wijk, H.A.R., Eds.; Radboud University Nijmegen: Nijmegen, The Netherlands, 2018; pp. 1-243, ISBN 978-94-6375-060-8.

188. Song, Y.; Morales, L.; Malik, A.S.; Mead, A.F.; Greer, C.D.; Mitchell, M.A.; Petrov, M.T.; Su, L.T.; Choi, M.E.; Rosenblum, S.T.; et al. Non-immunogenic utrophin gene therapy for the treatment of muscular dystrophy animal models. Nat. Med. 2019, 25, 1505-1511. [CrossRef]

189. Van Rossum, A.G.S.H.; Aartsen, W.M.; Meuleman, J.; Klooster, J.; Malysheva, A.; Versteeg, I.; Arsanto, J.P.; Le Bivic, A.; Wijnholds, J. Pals1/Mpp5 is required for correct localization of Crb1 at the subapical region in polarized Müller glia cells. Hum. Mol. Genet. 2006, 15, 2659-2672. [CrossRef]

190. Alves, C.H.; Sanz, A.S.; Park, B.; Pellissier, L.P.; Tanimoto, N.; Beck, S.C.; Huber, G.; Murtaza, M.; Richard, F.; Sridevi Gurubaran, I.; et al. Loss of CRB2 in the mouse retina mimics human retinitis pigmentosa due to mutations in the CRB1 gene. Hum. Mol. Genet. 2013, 22, 35-50. [CrossRef]

191. Alves, C.H.; Boon, N.; Mulder, A.A.; Koster, A.J.; Jost, C.R.; Wijnholds, J. CRB2 Loss in Rod Photoreceptors Is Associated with Progressive Loss of Retinal Contrast Sensitivity. Int. J. Mol. Sci. 2019, 20, 4069. [CrossRef] [PubMed]

192. Van de Pavert, S.A.; Meuleman, J.; Malysheva, A.; Aartsen, W.M.; Versteeg, I.; Tonagel, F.; Kamphuis, W.; McCabe, C.J.; Seeliger, M.W.; Wijnholds, J. A single amino acid substitution (Cys249Trp) in Crb1 causes retinal degeneration and deregulates expression of pituitary tumor transforming gene Pttg1. J. Neurosci. 2007, 27, 564-573. [CrossRef] [PubMed]

193. Alves, C.H.; Bossers, K.; Vos, R.M.; Essing, A.H.W.; Swagemakers, S.; van der Spek, P.J.; Verhaagen, J.; Wijnholds, J. Microarray and morphological analysis of early postnatal CRB2 mutant retinas on a pure C57BL/6J genetic background. PLoS ONE 2013, 8, e82532. [CrossRef] [PubMed]

194. Alves, C.H.; Pellissier, L.P.; Vos, R.M.; Garcia Garrido, M.; Sothilingam, V.; Seide, C.; Beck, S.C.; Klooster, J.; Furukawa, T.; Flannery, J.G.; et al. Targeted ablation of Crb2 in photoreceptor cells induces retinitis pigmentosa. Hum. Mol. Genet. 2014, 23, 3384-3401. [CrossRef] [PubMed] 
195. Quinn, P.M.; Alves, C.H.; Klooster, J.; Wijnholds, J. CRB2 in immature photoreceptors determines the superior-inferior symmetry of the developing retina to maintain retinal structure and function. Hum. Mol. Genet. 2018, 27, 3137-3153. [CrossRef]

196. Van De Pavert, S.A.; Sanz, A.S.; Aartsen, W.M.; Vos, R.M.; Versteeg, I.; Beck, S.C.; Klooster, J.; Seeliger, M.W.; Wijnholds, J. Crb1 is a determinant of retinal apical Müller glia cell features. Glia 2007, 55, 1486-1497. [CrossRef]

197. Van de Pavert, S.A.; Kantardzhieva, A.; Malysheva, A.; Meuleman, J.; Versteeg, I.; Levelt, C.; Klooster, J.; Geiger, S.; Seeliger, M.W.; Rashbass, P.; et al. Crumbs homologue 1 is required for maintenance of photoreceptor cell polarization and adhesion during light exposure. J. Cell Sci. 2004, 117, 4169-4177. [CrossRef]

198. Pellissier, L.P.; Alves, C.H.; Quinn, P.M.; Vos, R.M.; Tanimoto, N.; Lundvig, D.M.S.; Dudok, J.J.; Hooibrink, B.; Richard, F.; Beck, S.C.; et al. Targeted ablation of CRB1 and CRB2 in retinal progenitor cells mimics Leber congenital amaurosis. PLoS Genet. 2013, 9, e1003976. [CrossRef]

199. Pellissier, L.P.; Lundvig, D.M.S.; Tanimoto, N.; Klooster, J.; Vos, R.M.; Richard, F.; Sothilingam, V.; Garcia Garrido, M.; Le Bivic, A.; Seeliger, M.W.; et al. CRB2 acts as a modifying factor of CRB1-related retinal dystrophies in mice. Hum. Mol. Genet. 2014, 23, 3759-3771. [CrossRef]

200. Quinn, P.M.; Mulder, A.A.; Henrique Alves, C.; Desrosiers, M.; de Vries, S.I.; Klooster, J.; Dalkara, D.; Koster, A.J.; Jost, C.R.; Wijnholds, J. Loss of CRB2 in Müller glial cells modifies a CRB1-associated retinitis pigmentosa phenotype into a Leber congenital amaurosis phenotype. Hum. Mol. Genet. 2019, 28, 105-123. [CrossRef]

201. Kantardzhieva, A.; Gosens, I.; Alexeeva, S.; Punte, I.M.; Versteeg, I.; Krieger, E.; Neefjes-Mol, C.A.; Den Hollander, A.I.; Letteboer, S.J.F.F.; Klooster, J.; et al. MPP5 recruits MPP4 to the CRB1 complex in photoreceptors. Investig. Ophthalmol. Vis. Sci. 2005, 46, 2192-2201. [CrossRef] [PubMed]

202. Talib, M.; van Schooneveld, M.J.; van Genderen, M.M.; Wijnholds, J.; Florijn, R.J.; ten Brink, J.B.; Schalij-Delfos, N.E.; Dagnelie, G.; Cremers, F.P.M.; Wolterbeek, R.; et al. Genotypic and Phenotypic Characteristics of CRB1-Associated Retinal Dystrophies: A Long-Term Follow-up Study. Ophthalmology 2017, 124, 884-895. [CrossRef] [PubMed]

203. Borrás, T. The pathway from genes to gene therapy in glaucoma: A review of possibilities for using genes as glaucoma drugs. Asia-Pacific J. Ophthalmol. 2017, 6, 80-93.

204. Kong, D.H.; Kim, M.R.; Jang, J.H.; Na, H.J.; Lee, S. A review of anti-angiogenic targets for monoclonal antibody cancer therapy. Int. J. Mol. Sci. 2017, 18.

205. Pechan, P.; Rubin, H.; Lukason, M.; Ardinger, J.; DuFresne, E.; Hauswirth, W.W.; Wadsworth, S.C.; Scaria, A. Novel anti-VEGF chimeric molecules delivered by AAV vectors for inhibition of retinal neovascularization. Gene Ther. 2009, 16, 10-16. [CrossRef]

206. Heier, J.S.; Kherani, S.; Desai, S.; Dugel, P.; Kaushal, S.; Cheng, S.H.; Delacono, C.; Purvis, A.; Richards, S.; Le-Halpere, A.; et al. Intravitreous injection of AAV2-sFLT01 in patients with advanced neovascular age-related macular degeneration: A phase 1, open-label trial. Lancet 2017, 390, 50-61. [CrossRef]

207. Parker, M.; Bellec, J.; McFarland, T.; Scripps, V.; Appukuttan, B.; Hartzell, M.; Yeager, A.; Hady, T.; Mitrophanous, K.A.; Stout, T.; et al. Suppression of neovascularization of donor corneas by transduction with equine infectious anemia virus-based lentiviral vectors expressing endostatin and angiostatin. Hum. Gene Ther. 2014, 25, 408-418. [CrossRef]

208. Buchberger, A. The Therapeutic Utility of Factor I in the Treatment of Complement Dependent Pathophysiological Processes. Ph.D. Thesis, University of Leicester, Leicester, UK, 2016.

209. Liu, Y.; Fortmann, S.D.; Shen, J.; Wielechowski, E.; Tretiakova, A.; Yoo, S.; Kozarsky, K.; Wang, J.; Wilson, J.M.; Campochiaro, P.A. AAV8-antiVEGFfab Ocular Gene Transfer for Neovascular Age-Related Macular Degeneration. Mol. Ther. 2018, 26, 542-549. [CrossRef]

210. Cashman, S.M.; Ramo, K.; Kumar-Singh, R. A non membrane-targeted human soluble CD59 attenuates choroidal neovascularization in a model of age related macular degeneration. PLoS ONE 2011, 6. [CrossRef]

211. Tomita, H.; Sugano, E.; Isago, H.; Hiroi, T.; Wang, Z.; Ohta, E.; Tamai, M. Channelrhodopsin-2 gene transduced into retinal ganglion cells restores functional vision in genetically blind rats. Exp. Eye Res. 2010, 90, 429-436. [CrossRef] 
212. Douar, A.M.; Bouquet, C.; Pruneau, D.; Chavas, J.; Dalkara, D.; Duebel, J.; Benosman, R.; Chenegros, G.; Picaud, S.; Sahel, J.; et al. 268. Optogenetic Engineering of Retinal Ganglion Cells with AAV2.7m8-ChrimsonR-tdTomato (GS030-DP) Is Well Tolerated and Induces Functional Responses to Light in Non-Human Primates. Mol. Ther. 2016, 24, S106-S107. [CrossRef]

213. Lundstrom, K. Viral Vectors in Gene Therapy. Diseases 2018, 6, 42. [CrossRef]

214. Trapani, I. Adeno-Associated Viral Vectors as a Tool for Large Gene Delivery to the Retina. Genes 2019, 10, 287. [CrossRef] [PubMed]

215. Trapani, I.; Toriello, E.; de Simone, S.; Colella, P.; Iodice, C.; Polishchuk, E.V.; Sommella, A.; Colecchi, L.; Rossi, S.; Simonelli, F.; et al. Improved dual AAV vectors with reduced expression of truncated proteins are safe and effective in the retina of a mouse model of Stargardt disease. Hum. Mol. Genet. 2015, 24, 6811-6825. [CrossRef] [PubMed]

216. McClements, M.E.; Barnard, A.R.; Singh, M.S.; Charbel Issa, P.; Jiang, Z.; Radu, R.A.; MacLaren, R.E. An AAV Dual Vector Strategy Ameliorates the Stargardt Phenotype in Adult Abca4-/- Mice. Hum. Gene Ther. 2019, 30, 590-600. [CrossRef]

217. Kumar, N.; Stanford, W.; de Solis, C.; Aradhana; Abraham, N.D.; Dao, T.M.J.; Thaseen, S.; Sairavi, A.; Gonzalez, C.U.; Ploski, J.E. The development of an AAV-based CRISPR SaCas9 genome editing system that can be delivered to neurons in vivo and regulated via doxycycline and Cre-recombinase. Front. Mol. Neurosci. 2018, 11. [CrossRef]

218. Hanlon, K.S.; Kleinstiver, B.P.; Garcia, S.P.; Zaborowski, M.P.; Volak, A.; Spirig, S.E.; Muller, A.; Sousa, A.A.; Tsai, S.Q.; Bengtsson, N.E.; et al. High levels of AAV vector integration into CRISPR-induced DNA breaks. Nat. Commun. 2019, 10. [CrossRef]

219. Yu, W.; Mookherjee, S.; Chaitankar, V.; Hiriyanna, S.; Kim, J.W.; Brooks, M.; Ataeijannati, Y.; Sun, X.; Dong, L.; Li, T.; et al. Nrl knockdown by AAV-delivered CRISPR/Cas9 prevents retinal degeneration in mice. Nat. Commun. 2017, 8. [CrossRef]

220. Zhu, J.; Ming, C.; Fu, X.; Duan, Y.; Hoang, D.A.; Rutgard, J.; Zhang, R.; Wang, W.; Hou, R.; Zhang, D.; et al. Gene and mutation independent therapy via CRISPR-Cas9 mediated cellular reprogramming in rod photoreceptors. Cell Res. 2017, 27, 830-833. [CrossRef]

221. Kim, E.; Koo, T.; Park, S.W.; Kim, D.; Kim, K.; Cho, H.Y.; Song, D.W.; Lee, K.J.; Jung, M.H.; Kim, S.; et al. In vivo genome editing with a small Cas 9 orthologue derived from Campylobacter jejuni. Nat. Commun. 2017, 8, 14500. [CrossRef]

222. Jo, D.H.; Koo, T.; Cho, C.S.; Kim, J.H.; Kim, J.-S.; Kim, J.H. Long-Term Effects of In Vivo Genome Editing in the Mouse Retina Using Campylobacter jejuni Cas9 Expressed via Adeno-Associated Virus. Mol. Ther. 2019, 27, 130-136. [CrossRef] [PubMed]

223. Perez-Pinera, P.; Kocak, D.D.; Vockley, C.M.; Adler, A.F.; Kabadi, A.M.; Polstein, L.R.; Thakore, P.I.; Glass, K.A.; Ousterout, D.G.; Leong, K.W.; et al. RNA-guided gene activation by CRISPR-Cas9-based transcription factors. Nat. Methods 2013, 10, 973-976. [CrossRef] [PubMed]

224. Konermann, S.; Brigham, M.D.; Trevino, A.E.; Joung, J.; Abudayyeh, O.O.; Barcena, C.; Hsu, P.D.; Habib, N.; Gootenberg, J.S.; Nishimasu, H.; et al. Genome-scale transcriptional activation by an engineered CRISPR-Cas9 complex. Nature 2015, 517, 583-588. [CrossRef] [PubMed]

225. Lecomte, E.; Tournaire, B.; Cogné, B.; Dupont, J.B.; Lindenbaum, P.; Martin-Fontaine, M.; Broucque, F.; Robin, C.; Hebben, M.; Merten, O.W.; et al. Advanced characterization of DNA molecules in rAAV vector preparations by single-stranded virus next-generation sequencing. Mol. Ther-Nucleic Acids 2015, 4, e260. [CrossRef]

226. Bennicelli, J.; Wright, J.F.; Komaromy, A.; Jacobs, J.B.; Hauck, B.; Zelenaia, O.; Mingozzi, F.; Hui, D.; Chung, D.; Tonia, S.; et al. Reversal of Blindness in Animal Models of Leber Congenital Amaurosis Using Optimized AAV2-mediated Gene Transfer. Mol. Ther. 2010, 16, 458-465. [CrossRef]

227. Mignon, C.; Sodoyer, R.; Werle, B. Antibiotic-free selection in biotherapeutics: Now and forever. Pathogens 2015, 4, 157-181. [CrossRef]

228. Kay, M.A.; He, C.Y.; Chen, Z.Y. A robust system for production of minicircle DNA vectors. Nat. Biotechnol. 2010, 28, 1287-1289. [CrossRef]

229. Schnödt, M.; Schmeer, M.; Kracher, B.; Krüsemann, C.; Espinosa, L.E.; Grünert, A.; Fuchsluger, T.; Rischmüller, A.; Schleef, M.; Büning, H. DNA Minicircle Technology Improves Purity of Adeno-associated Viral Vector Preparations. Mol. Ther.-Nucleic Acids 2016, 5, e355. 
230. Bishop, B.M.; Santin, A.D.; Quirk, J.G.; Hermonat, P.L. Role of terminal repeat GAGC trimer, the major Rep78 binding site, in adeno-associated virus DNA replication. Febs Lett. 1996, 397, 97-100. [CrossRef]

231. Ryan, J.H.; Zolotukhin, S.; Muzyczka, N. Sequence requirements for binding of Rep68 to the adeno-associated virus terminal repeats. J. Virol. 1996, 70, 1542-1553. [CrossRef]

232. Zhou, X.; Zeng, X.; Fan, Z.; Li, C.; McCown, T.; Samulski, R.J.; Xiao, X. Adeno-associated virus of a single-polarity DNA genome is capable of transduction in vivo. Mol. Ther. 2008, 16, 494-499. [CrossRef] [PubMed]

233. Wang, X.S.; Ponnazhagan, S.; Srivastava, A. Rescue and replication of adeno-associated virus type 2 as well as vector DNA sequences from recombinant plasmids containing deletions in the viral inverted terminal repeats: Selective encapsidation of viral genomes in progeny virions. J. Virol. 1996, 70, 1668-1677. [CrossRef] [PubMed]

234. Wang, X.S.; Qing, K.; Ponnazhagan, S.; Srivastava, A. Adeno-associated virus type 2 DNA replication in vivo: Mutation analyses of the D sequence in viral inverted terminal repeats. J. Virol. 1997, 71, 3077-3082. [CrossRef] [PubMed]

235. Kwon, H.-J.; Qing, K.; Ponnazhagan, S.; Wang, X.-S.; Markusic, D.M.; Gupte, S.; Boye, S.; Srivastava, A. AAV D-sequence-mediated suppression of expression of a human major histocompatibility class II gene: Implications in the development of AAV vectors for modulating humoral immune response. Hum. Gene Ther. 2020, 31, 565-574. [CrossRef] [PubMed]

236. Samulski, R.J.; Srivastava, A.; Berns, K.I.; Muzyczka, N. Rescue of adeno-associated virus from recombinant plasmids: Gene correction within the terminal repeats of AAV. Cell 1983, 33, 135-143. [CrossRef]

237. Zhou, Q.; Tian, W.; Liu, C.; Lian, Z.; Dong, X.; Wu, X. Deletion of the B-B' and C-C' regions of inverted terminal repeats reduces rAAV productivity but increases transgene expression. Sci. Rep. 2017, 7. [CrossRef]

238. McAlister, V.J.; Owens, R.A. Substitution of adeno-associated virus Rep protein binding and nicking sites with human chromosome 19 sequences. Virol. J. 2010, 7, 218. [CrossRef]

239. Crémisi, C.; Pignatti, P.F.; Yaniv, M. Random location and absence of movement of the nucleosomes on SV 40 nucleoprotein complex isolated from infected cells. Biochem. Biophys. Res. Commun. 1976, 73, 548-554. [CrossRef]

240. Okada, T.; Uchibori, R.; Iwata-Okada, M.; Takahashi, M.; Nomoto, T.; Nonaka-Sarukawa, M.; Ito, T.; Liu, Y.; Mizukami, H.; Kume, A.; et al. A histone deacetylase inhibitor enhances recombinant adeno-associated virus-mediated gene expression in tumor cells. Mol. Ther. 2006, 13, 738-746. [CrossRef]

241. Crémisi, C.; Chestier, A.; Yaniv, M. Preferential association of newly synthesized histones with replicating SV40 DNA. Cell 1977, 12, 947-951. [CrossRef]

242. Mano, M.; Ippodrino, R.; Zentilin, L.; Zacchigna, S.; Giacca, M. Genome-wide RNAi screening identifies host restriction factors critical for in vivo AAV transduction. Proc. Natl. Acad. Sci. USA 2015, 112, 11276-11281. [CrossRef] [PubMed]

243. Provost, N.; Le Meur, G.; Weber, M.; Mendes-Madeira, A.; Podevin, G.; Cherel, Y.; Colle, M.A.; Deschamps, J.Y.; Moullier, P.; Rolling, F. Biodistribution of rAAV vectors following intraocular administration: Evidence for the presence and persistence of vector DNA in the optic nerve and in the brain. Mol. Ther. 2005, 11, 275-283. [CrossRef] [PubMed]

244. Miller, D.G.; Petek, L.M.; Russell, D.W. Adeno-associated virus vectors integrate at chromosome breakage sites. Nat. Genet. 2004, 36, 767-773. [CrossRef] [PubMed]

245. Nakai, H.; Yant, S.R.; Storm, T.A.; Fuess, S.; Meuse, L.; Kay, M.A. Extrachromosomal recombinant adeno-associated virus vector genomes are primarily responsible for stable liver transduction in vivo. J. Virol. 2001, 75, 6969-6976. [CrossRef]

246. Colella, P.; Ronzitti, G.; Mingozzi, F. Emerging Issues in AAV-Mediated In Vivo Gene Therapy. Mol. Ther.-Methods Clin. Dev. 2018, 8, 87-104. [CrossRef]

247. Nakai, H.; Montini, E.; Fuess, S.; Storm, T.A.; Grompe, M.; Kay, M.A. AAV serotype 2 vectors preferentially integrate into active genes in mice. Nat. Genet. 2003, 34, 297-302. [CrossRef]

248. Ceiler, J.; Afzal, S.; Leuchs, B.; Fronza, R.; Lulay, C.; Büning, H.; Schmidt, M.; Gil-Farina, I. Wild-Type and Recombinant AAV Integration in Human Cardiomyocytes: Focus on Mitochondrial Genome. In Proceedings of the AAV Vector Biology, 10 May 2017. Available online: https://www.researchgate.net/publication/316699961_Wild-Type_and_Recombinant_AAV_ Integration_in_Human_Cardiomyocytes_Focus_on_Mitochondrial_Genome (accessed on 10 June 2020). 
249. Gil-Farina, I.; Fronza, R.; Kaeppel, C.; Lopez-Franco, E.; Ferreira, V.; D'Avola, D.; Benito, A.; Prieto, J.; Petry, H.; Gonzalez-Aseguinolaza, G.; et al. Recombinant AAV Integration Is Not Associated with Hepatic Genotoxicity in Nonhuman Primates and Patients. Mol. Ther. 2016, 24, 1100-1105. [CrossRef]

250. Maeder, M.L.; Stefanidakis, M.; Wilson, C.J.; Baral, R.; Barrera, L.A.; Bounoutas, G.S.; Bumcrot, D.; Chao, H.; Ciulla, D.M.; DaSilva, J.A.; et al. Development of a gene-editing approach to restore vision loss in Leber congenital amaurosis type 10. Nat. Med. 2019, 25, 229-233. [CrossRef]

251. Wang, Z.; Lisowski, L.; Finegold, M.J.; Nakai, H.; Kay, M.A.; Grompe, M. AAV vectors containing rDNA homology display increased chromosomal integration and transgene persistence. Mol. Ther. 2012, 20, 1902-1911. [CrossRef]

252. Hirsch, M.L. Adeno-associated virus inverted terminal repeats stimulate gene editing. Gene Ther. 2015, 22, 190-195. [CrossRef]

253. Ronzitti, G.; Bortolussi, G.; van Dijk, R.; Collaud, F.; Charles, S.; Leborgne, C.; Vidal, P.; Martin, S.; Gjata, B.; Sola, M.S.; et al. A translationally optimized AAV-UGT1A1 vector drives safe and long-lasting correction of Crigler-Najjar syndrome. Mol. Ther.-Methods Clin. Dev. 2016, 3, 16049. [CrossRef]

254. McCarty, D.M.; Monahan, P.E.; Samulski, R.J. Self-complementary recombinant adeno-associated virus (scAAV) vectors promote efficient transduction independently of DNA synthesis. Gene Ther. 2001, 8, 1248-1254. [CrossRef] [PubMed]

255. McCarty, D.M. Self-complementary AAV vectors; advances and applications. Mol. Ther. 2008, 16, 1648-1656. [CrossRef] [PubMed]

256. Koilkonda, R.D.; Chou, T.H.; Porciatti, V.; Hauswirth, W.W.; Guy, J. Induction of rapid and highly efficient expression of the human ND4 complex I subunit in the mouse visual system by self-complementary adeno-associated virus. Arch. Ophthalmol. 2010, 128, 876-883. [CrossRef] [PubMed]

257. Yokoi, K.; Kachi, S.; Zhang, H.S.; Gregory, P.D.; Spratt, S.K.; Samulski, R.J.; Campochiaro, P.A. Ocular gene transfer with self-complementary AAV vectors. Investig. Ophthalmol. Vis. Sci. 2007, 48, 3324-3328. [CrossRef]

258. Wright, J.F.; Zelenaia, O. Vector characterization methods for quality control testing of recombinant adeno-associated viruses. Methods Mol. Biol. 2011, 737, 247-278.

259. François, A.; Bouzelha, M.; Lecomte, E.; Broucque, F.; Penaud-Budloo, M.; Adjali, O.; Moullier, P.; Blouin, V.; Ayuso, E. Accurate Titration of Infectious AAV Particles Requires Measurement of Biologically Active Vector Genomes and Suitable Controls. Mol. Ther.-Methods Clin. Dev. 2018, 10, 223-236.

260. Couto, L.; Buchlis, G.; Farjo, R.; High, K.A. Poster C0048 ARVO: Potency Assay for AAV Vector Encoding Retinal Pigment Epithelial 65 Protein. Investig. Ophthalmol. Vis. Sci. 2016, 57, 1.

261. Patrício, M.I.; Barnard, A.R.; Cox, C.I.; Blue, C.; MacLaren, R.E. The Biological Activity of AAV Vectors for Choroideremia Gene Therapy Can Be Measured by In Vitro Prenylation of RAB6A. Mol. Ther-Methods Clin. Dev. 2018, 9, 288-295.

262. Wang, L.; Xiao, R.; Andres-Mateos, E.; Vandenberghe, L.H. Single stranded adeno-associated virus achieves efficient gene transfer to anterior segment in the mouse eye. PLoS ONE 2017, 12. [CrossRef]

263. Borrás, T.; Xue, W.; Choi, V.W.; Bartlett, J.S.; Li, G.; Samulski, R.J.; Chisolm, S.S. Mechanisms of AAV transduction in glaucoma-associated human trabecular meshwork cells. J. Gene Med. 2006, 8, 589-602. [CrossRef] [PubMed]

264. Ellis, B.L.; Hirsch, M.L.; Barker, J.C.; Connelly, J.P.; Steininger, R.J.; Porteus, M.H. A survey of ex vivo/in vitro transduction efficiency of mammalian primary cells and cell lines with Nine natural adeno-associated virus (AAV1-9) and one engineered adeno-associated virus serotype. Virol. J. 2013, 10, 74. [CrossRef] [PubMed]

265. Gonzalez-Cordero, A.; Goh, D.; Kruczek, K.; Naeem, A.; Fernando, M.; Kleine Holthaus, S.M.; Takaaki, M.; Blackford, S.J.I.; Kloc, M.; Agundez, L.; et al. Assessment of AAV Vector Tropisms for Mouse and Human Pluripotent Stem Cell-Derived RPE and Photoreceptor Cells. Hum. Gene Ther. 2018, 29, 1124-1139. [CrossRef] [PubMed]

266. Sayyad, Z.; Sirohi, K.; Radha, V.; Swarup, G. 661W is a retinal ganglion precursor-like cell line in which glaucoma-associated optineurin mutants induce cell death selectively. Sci. Rep. 2017, 7. [CrossRef]

267. Tan, E.; Ding, X.-Q.; Saadi, A.; Agarwal, N.; Naash, M.I.; Al-Ubaidi, M.R. Expression of cone-photoreceptor-specific antigens in a cell line derived from retinal tumors in transgenic mice. Investig. Ophthalmol. Vis. Sci. 2004, 45, 764-768. [CrossRef] 
268. Ryals, R.C.; Boye, S.L.; Dinculescu, A.; Hauswirth, W.W.; Boye, S.E. Quantifying transduction efficiencies of unmodified and tyrosine capsid mutant AAV vectors in vitro using two ocular cell lines. Mol. Vis. 2011, 17, 1090-1102.

269. McDougald, D.S.; Duong, T.T.; Palozola, K.C.; Marsh, A.; Papp, T.E.; Mills, J.A.; Zhou, S.; Bennett, J. CRISPR Activation Enhances In Vitro Potency of AAV Vectors Driven by Tissue-Specific Promoters. Mol. Ther.-Methods Clin. Dev. 2019, 13, 380-389. [CrossRef]

270. Drivas, T.G.; Bennett, J. Compositions and Methods for Treatment of Disorders Related to CEP290. U.S. Patent 10301366B2, 22 January 2015.

271. Katoh, Y.; Michisaka, S.; Nozaki, S.; Funabashi, T.; Hirano, T.; Takei, R.; Nakayama, K. Practical method for targeted disruption of ciliarelated genes by using CRISPR/Cas9-mediated, homology-independent knock-in system. Mol. Biol. Cell 2017, 28, 898-906. [CrossRef]

272. Klimczak, R.R.; Koerber, J.T.; Dalkara, D.; Flannery, J.G.; Schaffer, D.V. A novel adeno-associated viral variant for efficient and selective intravitreal transduction of rat Müller cells. PLoS ONE 2009, 4, e7467. [CrossRef]

273. Zhang, Z.; Ma, Z.; Zou, W.; Guo, H.; Liu, M.; Ma, Y.; Zhang, L. The Appropriate Marker for Astrocytes: Comparing the Distribution and Expression of Three Astrocytic Markers in Different Mouse Cerebral Regions. Biomed Res. Int. 2019, 2019, 1-15. [CrossRef] [PubMed]

274. Vecino, E.; Rodriguez, F.D.; Ruzafa, N.; Pereiro, X.; Sharma, S.C. Glia-neuron interactions in the mammalian retina. Prog. Retin. Eye Res. 2016, 51, 1-40. [CrossRef]

275. Lawrence, J.M.; Singhal, S.; Bhatia, B.; Keegan, D.J.; Reh, T.A.; Luthert, P.J.; Khaw, P.T.; Limb, G.A. MIO-M1 Cells and Similar Müller Glial Cell Lines Derived from Adult Human Retina Exhibit Neural Stem Cell Characteristics. Stem Cells 2007, 25, 2033-2043. [CrossRef] [PubMed]

276. Limb, G.A.; Salt, T.E.; Munro, P.M.G.; Moss, S.E.; Khaw, P.T. In vitro characterization of a spontaneously immortalized human Müller cell line (MIO-M1). Investig. Ophthalmol. Vis. Sci. 2002, 43, 864-869. [PubMed]

277. Koch, P.; de Greef, S.; Chtarto, A.; Kemp, T.; Bockstae, O.; Velu, T.; Caspers, L.; Tenenbaum, L. ARVO abstract: In vitro comparison of AAV-mediated eGFP gene transfer on Müller cells and ARPE cells. Investig. Ophthalmol. Vis. Sci. 2004, 45.

278. Mellough, C.B.; Sernagor, E.; Moreno-Gimeno, I.; Steel, D.H.W.; Lako, M. Efficient stage-specific differentiation of human pluripotent stem cells toward retinal photoreceptor cells. Stem Cells 2012, 30, 673-686. [CrossRef]

279. Cereso, N.; Pequignot, M.O.; Robert, L.; Becker, F.; De Luca, V.; Nabholz, N.; Rigau, V.; De Vos, J.; Hamel, C.P.; Kalatzis, V. Proof of concept for AAV2/5-mediated gene therapy in iPSC-derived retinal pigment epithelium of a choroideremia patient. Mol. Ther.-Methods Clin. Dev. 2014, 1, 14011. [CrossRef]

280. Duong, T.T.; Vasireddy, V.; Ramachandran, P.; Herrera, P.S.; Leo, L.; Merkel, C.; Bennett, J.; Mills, J.A. Use of induced pluripotent stem cell models to probe the pathogenesis of Choroideremia and to develop a potential treatment. Stem Cell Res. 2018, 27, 140-150. [CrossRef]

281. Brydon, E.M.; Bronstein, R.; Buskin, A.; Lako, M.; Pierce, E.A.; Fernandez-Godino, R. AAV-mediated gene augmentation therapy restores critical functions in mutant iPSC-derived PRPF31+/- cells. bioRxiv 2019, 729160. [CrossRef]

282. Wright, J.F.; Sumaroka, M. Rab Escort Protein Potency Assay. U.S. Patent 201662418637P, 11 September 2019.

283. Garita-Hernandez, M.; Guibbal, L.; Toualbi, L.; Routet, F.; Chaffiol, A.; Winckler, C.; Harinquet, M.; Robert, C.; Fouquet, S.; Bellow, S.; et al. Optogenetic light sensors in human retinal organoids. Front. Neurosci. $2018,12$. [CrossRef] [PubMed]

284. Garita-Hernandez, M.; Routet, F.; Guibbal, L.; Khabou, H.; Toualbi, L.; Riancho, L.; Reichman, S.; Duebel, J.; Sahel, J.A.; Goureau, O.; et al. AAV-mediated gene delivery to 3D retinal organoids derived from human induced pluripotent stem cells. Int. J. Mol. Sci. 2020, 21, 994. [CrossRef] [PubMed]

285. Dudek, A.M.; Pillay, S.; Puschnik, A.S.; Nagamine, C.M.; Cheng, F.; Qiu, J.; Carette, J.E.; Vandenberghe, L.H. An Alternate Route for Adeno-associated Virus (AAV) Entry Independent of AAV Receptor. J. Virol. 2018, 92. [CrossRef] [PubMed]

286. Akl, M.R.; Nagpal, P.; Ayoub, N.M.; Tai, B.; Prabhu, S.A.; Capac, C.M.; Gliksman, M.; Goy, A.; Suh, K.S. Molecular and clinical significance of fibroblast growth factor 2 (FGF2/bFGF) in malignancies of solid and hematological cancers for personalized therapies. Oncotarget 2016, 7, 44735-44762. [CrossRef]

287. ThermoScientific Growth Factors in HyClone Cell Culture Serum. Available online: https://static. thermoscientific.com/images/D22225 \{\}.pdf (accessed on 11 June 2020). 
288. Qing, K.; Mah, C.; Hansen, J.; Zhou, S.; Dwarki, V.; Srivastava, A. Human fibroblast growth factor receptor 1 is a co-receptor for infection by adeno-associated virus 2. Nat. Med. 1999, 5, 71-77. [CrossRef]

289. Capowski, E.E.; Samimi, K.; Mayerl, S.J.; Phillips, M.J.; Pinilla, I.; Howden, S.E.; Saha, J.; Jansen, A.D.; Edwards, K.L.; Jager, L.D.; et al. Reproducibility and staging of 3D human retinal organoids across multiple pluripotent stem cell lines. Development 2019, 146. [CrossRef]

290. Mellough, C.B.; Collin, J.; Queen, R.; Hilgen, G.; Dorgau, B.; Zerti, D.; Felemban, M.; White, K.; Sernagor, E.; Lako, M. Systematic Comparison of Retinal Organoid Differentiation from Human Pluripotent Stem Cells Reveals Stage Specific, Cell Line, and Methodological Differences. Stem Cells Transl. Med. 2019, 8, 694-706. [CrossRef]

291. Achberger, K.; Haderspeck, J.C.; Kleger, A.; Liebau, S. Stem cell-based retina models. Adv. Drug Deliv. Rev. 2019, 140, 33-50. [CrossRef]

292. Wiley, L.A.; Burnight, E.R.; Kaalberg, E.E.; Jiao, C.; Riker, M.J.; Halder, J.A.; Luse, M.A.; Han, I.C.; Russell, S.R.; Sohn, E.H.; et al. Assessment of Adeno-Associated Virus Serotype Tropism in Human Retinal Explants. Hum. Gene Ther. 2018, 29, 424-436. [CrossRef]

293. Khabou, H.; Garita-Hernandez, M.; Chaffiol, A.; Reichman, S.; Jaillard, C.; Brazhnikova, E.; Bertin, S.; Forster, V.; Desrosiers, M.; Winckler, C.; et al. Noninvasive gene delivery to foveal cones for vision restoration. Jci Insight 2018, 3. [CrossRef] [PubMed]

294. Hickey, D.G.; Edwards, T.L.; Barnard, A.R.; Singh, M.S.; de Silva, S.R.; McClements, M.E.; Flannery, J.G.; Hankins, M.W.; MacLaren, R.E. Tropism of engineered and evolved recombinant AAV serotypes in the rd1 mouse and ex vivo primate retina. Gene Ther. 2017, 24, 787-800. [CrossRef] [PubMed]

295. Buck, T.M.; Pellissier, L.P.; Vos, R.M.; van Dijk, E.H.C.C.; Boon, C.J.F.; Wijnholds, J. AAV serotype testing on cultured human donor retinal explants. In Methods in Molecular Biology; Boon, C.J.F., Wijnholds, J., Eds.; Humana Press: New York, NY, USA, 2018; Volume 1715, pp. 275-288, ISBN 978-1-4939-7522-8.

296. Reid, C.A.; Ertel, K.J.; Lipinski, D.M. Improvement of photoreceptor targeting via intravitreal delivery in mouse and human retina using combinatory rAAV2 capsid mutant vectors. Investig. Ophthalmol. Vis. Sci. 2017, 58, 6429-6439. [CrossRef] [PubMed]

297. Buck, T.M.; Quinn, P.M.; Celso Alves, H.; Van Dijk, E.; Ohonin, C.; Boon, C.J.F.; Wijnholds, J. Potency assay for AAV-gene vectors in human iPSCs-derived retinas and donor retinas | IOVS | ARVO Journals. Investig. Ophthalmol. Vis. Sci. 2017, 58, 4093.

298. Singh, H.P.; Wang, S.; Stachelek, K.; Lee, S.; Reid, M.W.; Thornton, M.E.; Craft, C.M.; Grubbs, B.H.; Cobrinik, D. Developmental stage-specific proliferation and retinoblastoma genesis in RB-deficient human but not mouse cone precursors. Proc. Natl. Acad. Sci. USA 2018, 115, E9391-E9400. [CrossRef] [PubMed]

299. Petit, L.; Ma, S.; Cheng, S.-Y.; Gao, G.; Punzo, C. Rod Outer Segment Development Influences AAV-Mediated Photoreceptor Transduction After Subretinal Injection. Hum. Gene Ther. 2017, 28, 464-481. [CrossRef]

300. Surace, E.M.; Auricchio, A.; Reich, S.J.; Glover, E.; Pineles, S.; Tang, W.; O'Connor, E.; Lyubarsky, A.; Savchenko, A.; Pugh, E.N.; et al. Delivery of Adeno-Associated Virus Vectors to the Fetal Retina: Impact of Viral Capsid Proteins on Retinal Neuronal Progenitor Transduction. J. Virol. 2003, 77, 7957-7963. [CrossRef]

301. Xiong, W.; Cepko, C. Distinct Expression Patterns of AAV8 Vectors with Broadly Active Promoters from Subretinal Injections of Neonatal Mouse Eyes at Two Different Ages. Adv. Exp. Med. Biol. 2016, 854, 501-507.

302. Matsumoto, B.; Blanks, J.C.; Ryan, S.J. Topographic variations in the rabbit and primate internal limiting membrane. | IOVS | ARVO Journals. Investig. Ophthalmol. Vis. Sci. 1984, 2, 71-82.

303. Timmers, A.M.; Newmark, J.A.; Turunen, H.T.; Farivar, T.; Liu, J.; Song, C.; Ye, G.J.; Pennock, S.; Gaskin, C.; Knop, D.R.; et al. Ocular Inflammatory Response to Intravitreal Injection of Adeno-Associated Virus Vector: Relative Contribution of Genome and Capsid. Hum. Gene Ther. 2020, 31, 80-89. [CrossRef]

304. Dalkara, D.; Kolstad, K.D.; Caporale, N.; Visel, M.; Klimczak, R.R.; Schaffer, D.V.; Flannery, J.G. Inner limiting membrane barriers to aav-mediated retinal transduction from the vitreous. Mol. Ther. 2009, 17, 2096-2102. [CrossRef]

305. Cehajic-Kapetanovic, J.; Milosavljevic, N.; Bedford, R.A.; Lucas, R.J.; Bishop, P.N. Efficacy and Safety of Glycosidic Enzymes for Improved Gene Delivery to the Retina following Intravitreal Injection in Mice. Mol. Ther.-Methods Clin. Dev. 2018, 9, 192-202. [CrossRef] [PubMed]

306. Song, H.; Bush, R.A.; Zeng, Y.; Qian, H.; Wu, Z.; Sieving, P.A. Trans-ocular Electric Current In Vivo Enhances AAV-Mediated Retinal Gene Transduction after Intravitreal Vector Administration. Mol. Ther.-Methods Clin. Dev. 2019, 13, 77-85. [CrossRef] [PubMed] 
307. Dias, M.S.; Araujo, V.G.; Vasconcelos, T.; Li, Q.; Hauswirth, W.W.; Linden, R.; Petrs-Silva, H. Retina transduction by rAAV2 after intravitreal injection: Comparison between mouse and rat. Gene Ther. 2019, 26, 479-490. [CrossRef] [PubMed]

308. Kolstad, K.D.; Dalkara, D.; Guerin, K.; Visel, M.; Hoffmann, N.; Schaffer, D.V.; Flannery, J.G. Changes in adeno-associated virus-mediated gene delivery in retinal degeneration. Hum. Gene Ther. 2010, 21, 571-578. [CrossRef] [PubMed]

309. Charbel Issa, P.; de Silva, S.R.; Lipinski, D.M.; Singh, M.S.; Mouravlev, A.; You, Q.; Barnard, A.R.; Hankins, M.W.; During, M.J.; MacLaren, R.E. Assessment of Tropism and Effectiveness of New Primate-Derived Hybrid Recombinant AAV Serotypes in the Mouse and Primate Retina. PLoS ONE 2013, 8, e0060361. [CrossRef]

310. Zeng, Y.; Qian, H.; Wu, Z.; Marangoni, D.; Sieving, P.A.; Bush, R.A. AAVrh-10 transduces outer retinal cells in rodents and rabbits following intravitreal administration. Gene Ther. 2019, 26, 386-398. [CrossRef]

311. Giove, T.J.; Sena-Esteves, M.; Eldred, W.D. Transduction of the inner mouse retina using AAVrh8 and AAVrh10 via intravitreal injection. Exp. Eye Res. 2010, 91, 652-659. [CrossRef]

312. Lovric, J.; Mano, M.; Zentilin, L.; Eulalio, A.; Zacchigna, S.; Giacca, M. Terminal differentiation of cardiac and skeletal myocytes induces permissivity to AAV transduction by relieving inhibition imposed by DNA damage response proteins. Mol. Ther. 2012, 20, 2087-2097. [CrossRef]

313. Moreno, M.L.; Mérida, S.; Bosch-Morell, F.; Miranda, M.; Villar, V.M. Autophagy dysfunction and oxidative stress, two related mechanisms implicated in retinitis pigmentosa. Front. Physiol. 2018, 9, 1008. [CrossRef]

314. Blasiak, J.; Piechota, M.; Pawlowska, E.; Szatkowska, M.; Sikora, E.; Kaarniranta, K. Cellular senescence in age-related macular degeneration: Can autophagy and DNA damage response play a role? Oxid. Med. Cell. Longev. 2017, 2017. [CrossRef]

315. D'Adda Di Fagagna, F. Living on a break: Cellular senescence as a DNA-damage response. Nat. Rev. Cancer 2008, 8, 512-522. [CrossRef]

316. Lotery, A.J.; Yang, G.S.; Mullins, R.F.; Russell, S.R.; Schmidt, M.; Stone, E.M.; Lindbloom, J.D.; Chiorini, J.A.; Kotin, R.M.; Davidson, B.L. Adeno-Associated Virus Type 5: Transduction Efficiency and Cell-Type Specificity in the Primate Retina. Hum. Gene Ther. 2003, 14, 1663-1671. [CrossRef] [PubMed]

317. Gao, G.-P.; Auricchio, A.; Wang, L.; Johnston, J.; Hammill, D.; Raper, S.E.; Grant, R.; Bennett, J.; Wilson, J.M.; Gao, G.-P.; et al. 561. Evaluation of AAV Vectors Based on Serotypes 1,2 and 5 in Non-Human Primate Muscle, Liver and Retina. Mol. Ther. 2002, 5, S184.

318. Vandenberghe, L.H.; Bell, P.; Maguire, A.M.; Xiao, R.; Hopkins, T.B.; Grant, R.; Bennett, J.; Wilson, J.M. AAV9 targets cone photoreceptors in the nonhuman primate retina. PLoS ONE 2013, 8, e53463. [CrossRef]

319. Ramachandran, P.S.; Lee, V.; Wei, Z.; Song, J.Y.; Casal, G.; Cronin, T.; Willett, K.; Huckfeldt, R.; Morgan, J.I.W.; Aleman, T.S.; et al. Evaluation of Dose and Safety of AAV7m8 and AAV8BP2 in the Non-Human Primate Retina. Hum. Gene Ther. 2017, 28, 154-167. [CrossRef] [PubMed]

320. Carvalho, L.S.; Xiao, R.; Wassmer, S.J.; Langsdorf, A.; Zinn, E.; Pacouret, S.; Shah, S.; Comander, J.I.; Kim, L.A.; Lim, L.; et al. Synthetic Adeno-Associated Viral Vector Efficiently Targets Mouse and Nonhuman Primate Retina in Vivo. Hum. Gene Ther. 2018, 29, 771-784. [CrossRef]

321. Boye, S.E.; Alexander, J.J.; Boye, S.L.; Witherspoon, C.D.; Sandefer, K.J.; Conlon, T.J.; Erger, K.; Sun, J.; Ryals, R.; Chiodo, V.A.; et al. The Human Rhodopsin Kinase Promoter in an AAV5 Vector Confers Rod- and Cone-Specific Expression in the Primate Retina. Hum. Gene Ther. 2012, 23, 1101-1115. [CrossRef]

322. Yin, L.; Greenberg, K.; Hunter, J.J.; Dalkara, D.; Kolstad, K.D.; Masella, B.D.; Wolfe, R.; Visel, M.; Stone, D.; Libby, R.T.; et al. Intravitreal injection of AAV2 transduces macaque inner retina. Investig. Ophthalmol. Vis. Sci. 2011, 52, 2775-2783. [CrossRef]

323. Takahashi, K.; Igarashi, T.; Miyake, K.; Kobayashi, M.; Yaguchi, C.; Iijima, O.; Yamazaki, Y.; Katakai, Y.; Miyake, N.; Kameya, S.; et al. Improved Intravitreal AAV-Mediated Inner Retinal Gene Transduction after Surgical Internal Limiting Membrane Peeling in Cynomolgus Monkeys. Mol. Ther. 2017, 25, $296-302$. [CrossRef]

324. Xiong, W.; Wu, D.M.; Xue, Y.; Wang, S.K.; Chung, M.J.; Ji, X.; Rana, P.; Zhao, S.R.; Mai, S.; Cepko, C.L. AAV cis-regulatory sequences are correlated with ocular toxicity. Proc. Natl. Acad. Sci. USA 2019, 116, 5785-5794. [CrossRef]

325. Peirson, S.N.; Brown, L.A.; Pothecary, C.A.; Benson, L.A.; Fisk, A.S. Light and the laboratory mouse. J. Neurosci. Methods 2018, 300, 26-36. [CrossRef] [PubMed] 
326. Khabou, H.; Cordeau, C.; Pacot, L.; Fisson, S.; Dalkara, D. Dosage Thresholds and Influence of Transgene Cassette in Adeno-Associated Virus-Related Toxicity. Hum. Gene Ther. 2018, 29, 1235-1241. [CrossRef] [PubMed]

327. Mingozzi, F.; High, K.A. Therapeutic in vivo gene transfer for genetic disease using AAV: Progress and challenges. Nat. Rev. Genet. 2011, 12, 341-355. [CrossRef] [PubMed]

(C) 2020 by the authors. Licensee MDPI, Basel, Switzerland. This article is an open access article distributed under the terms and conditions of the Creative Commons Attribution (CC BY) license (http://creativecommons.org/licenses/by/4.0/). 